\title{
IntechOpen
}

\section{Sheep Farming \\ An Approach to Feed, Growth and Health}

Edited by António Monteiro

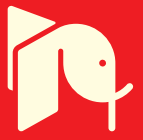





\section{Sheep Farming - An Approach to Feed, Growth and Health \\ Edited by António Monteiro}



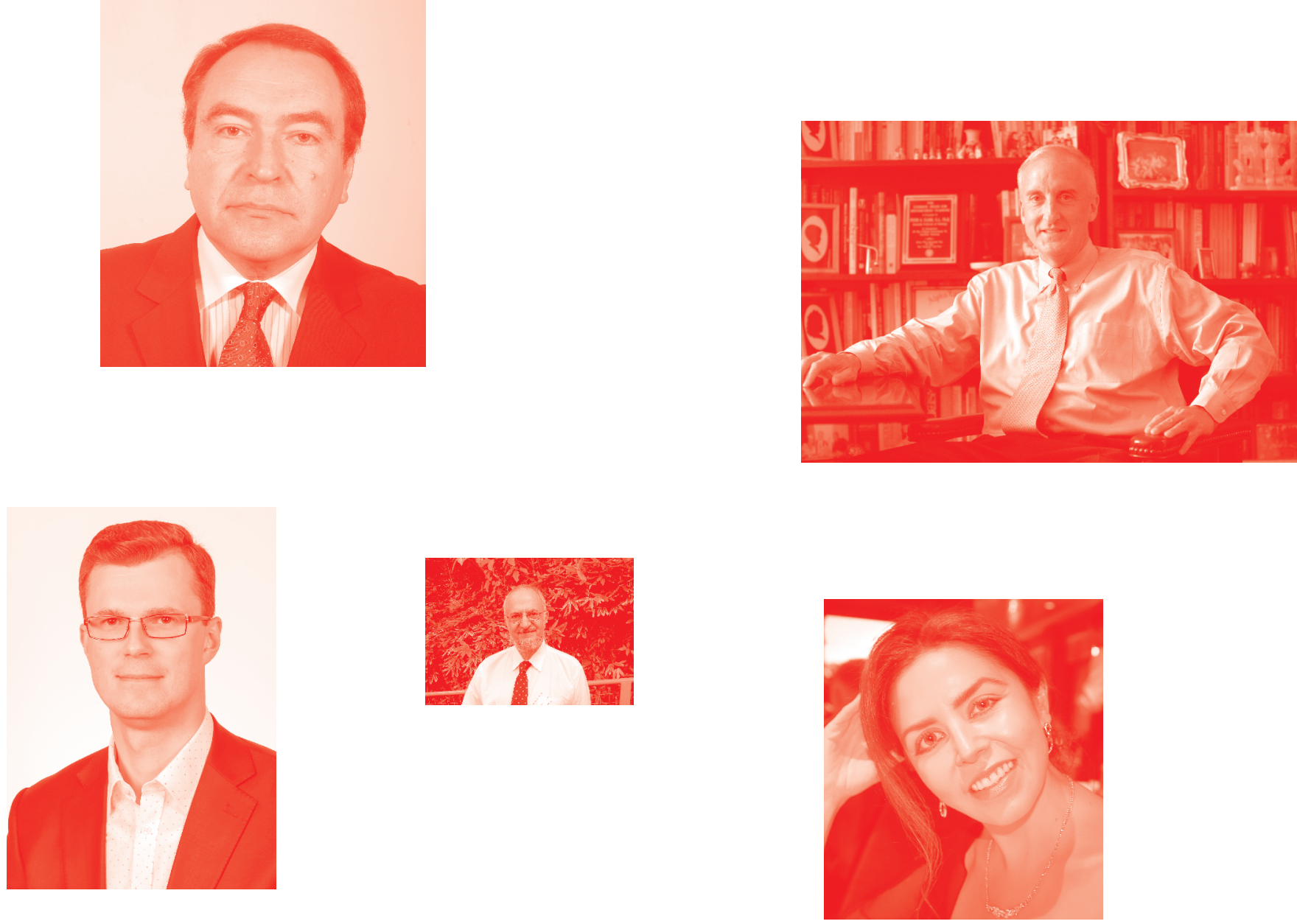

Supporting open minds since 2005
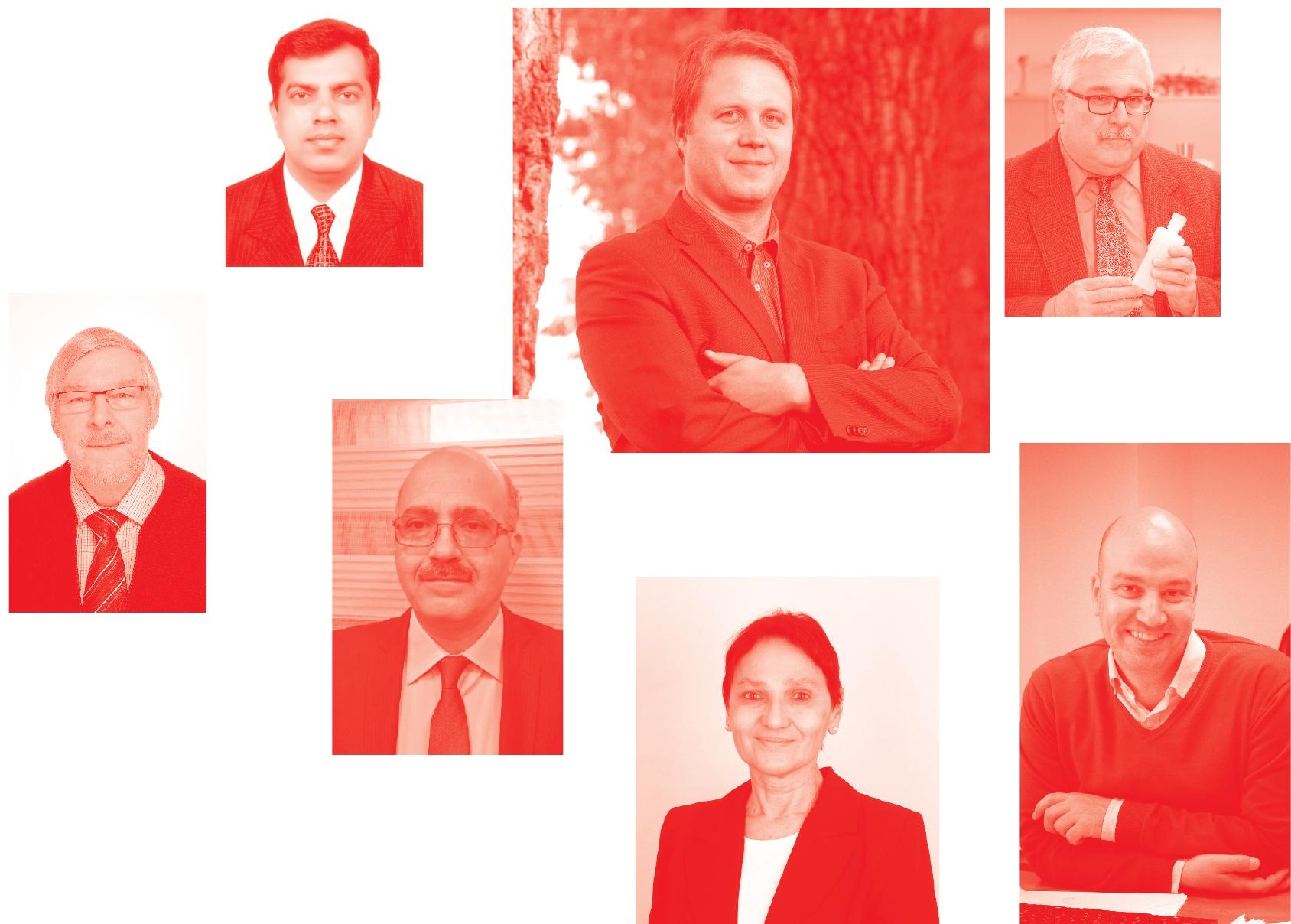
Sheep Farming - An Approach to Feed, Growth and Health

http: //dx. doi. org/10.5772/intechopen. 78842

Edited by António Monteiro

\section{Contributors}

Hamidou Nantoumé, Samir Medjekal, Mouloud Ghadbane, Tadesse Sisay Amare, Gebeyehu Goshu Negia, Berhan Tamir Mersso, António Cardoso Monteiro, Sérgio Santos, José Manuel Costa, Fernando Esteves, Luis Miguel Ferrer , Juan Jose Ramos, Delia Lacasta, Enrique Castells Perez, Héctor Ruíz, María Climent

() The Editor(s) and the Author(s) 2021

The rights of the editor(s) and the author(s) have been asserted in accordance with the Copyright, Designs and Patents Act 1988. All rights to the book as a whole are reserved by INTECHOPEN LIMITED . The book as a whole (compilation) cannot be reproduced, distributed or used for commercial or non-commercial purposes without INTECHOPEN LIMITED's written permission. Enquiries concerning the use of the book should be directed to INTECHOPEN LIMITED rights and permissions department (permissions@intechopen.com).

Violations are liable to prosecution under the governing Copyright Law .

\section{(cc) BY}

Individual chapters of this publication are distributed under the terms of the Creative Commons Attribution 3.๑ Unported License which permits commercial use, distribution and reproduction of the individual chapters, provided the original author(s) and source publication are appropriately acknowledged. If so indicated, certain images may not be included under the Creative Commons license. In such cases users will need to obtain permission from the license holder to reproduce the material. More details and guidelines concerning content reuse and adaptation can be found at http : //www . intechopen . com/copyright-policy. html .

\section{Notice}

Statements and opinions expressed in the chapters are these of the individual contributors and not necessarily those of the editors or publisher. No responsibility is accepted for the accuracy of information contained in the published chapters. The publisher assumes no responsibility for any damage or injury to persons or property arising out of the use of any materials, instructions, methods or ideas contained in the book.

First published in London, United Kingdom, 2021 by IntechOpen IntechOpen is the global imprint of INTECHOPEN LIMITED, registered in England and Wales, registration number: 11086078,5 Princes Gate Court, London, SW7 2QJ, United Kingdom Printed in Croatia

British Library Cataloguing-in-Publication Data

A catalogue record for this book is available from the British Library

Additional hard and PDF copies can be obtained from orders@intechopen.com

Sheep Farming - An Approach to Feed, Growth and Health

Edited by António Monteiro

p. $\mathrm{cm}$.

Print ISBN 978-1-78985-975-1

Online ISBN 978-1-78985-976-8

eBook (PDF) ISBN 978-1-83880-307-๑ 


\title{
We are IntechOpen, \\ the world's leading publisher of Open Access books
}

Built by scientists, for scientists

\section{$5,100+$}

Open access books available

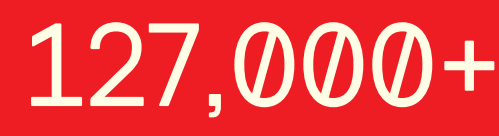

International authors and editors

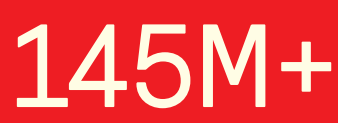

Downloads

\section{6}

Countries delivered to
Our authors are among the

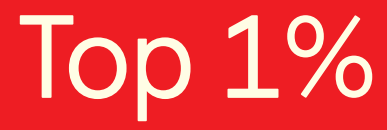

most cited scientists

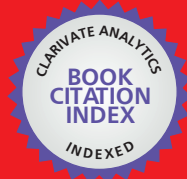 \\ WEB OF SCIENCE" \\ Selection of our books indexed in the Book Citation Index \\ in Web of Science ${ }^{\text {Th }}$ Core Collection (BKCI)

\section{Interested in publishing with us? \\ Contact book.department@intechopen.com}

Numbers displayed above are based on latest data collected.

For more information visit www.intechopen.com 



\section{Meet the editor}

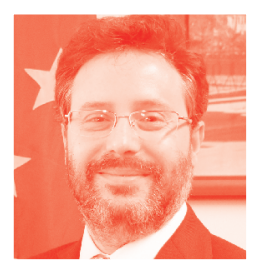

António Monteiro, Ph.D., is Coordinator Professor of Animal Science in the Agrarian School at the Polytechnic Institute of Viseu and a researcher in the CERNAS - Research Centre for Natural Resources, Environment and Society, Portugal. He received his Ph.D. in Agricultural Science-Animal Science from the University of Trás-os-Montes and Alto Douro, Portugal. He has published several peer-reviewed papers and has led a wide variety of research projects dealing with agricultural science and technologies. He held several management positions at the Agrarian School of Viseu prior to being appointed its president in 2016. 



\section{Contents}

$\begin{array}{lll}\text { Preface } & \text { XIII }\end{array}$

Section 1

Feeding Sheep

Chapter 1

Sheep Digestive Physiology and Constituents of Feeds

by Samir Medjekal and Mouloud Ghadbane

Chapter 2

Sheep Grazing Management in the Mountain Region: Serra da Estrela, Portugal

by António Monteiro, José Costa, Fernando Esteves and Sérgio Santos

Chapter 3

Sheep Feeding in the Sahel Countries of Africa

by Hamidou Nantoumé

Section 2

Sheep Growth and Health

Chapter 4

Body Weight Gain and Carcass Yield Characteristics of Wollo Highland Sheep and Their $\mathrm{F}_{1}$ Crossbreeds

by Tadesse Amare Sisay, Gebeyehu Goshu Negia and Berhan Tamir Mersso

Chapter 5

Use of Computed Tomography and Thermography for the Diagnosis of Respiratory Disorders in Adult Sheep

by Luis Miguel Ferrer, Juan José Ramos, Enrique Castells, Héctor Ruíz, María Climent and Delia Lacasta 



\section{Preface}

Sheep farming is mainly important in the poorest regions of the world, particularly in those where the country itself has few economic resources. Thus, this activity serves as a livelihood for many families, ensuring their survival. As such, it is important that sheep farming develops in such a way as to improve economic conditions.

This book examines ways to use natural resources in sheep farming. Section 1 discusses sheep feeding and examines how sheep digest feeds in the Sahel countries. It also examines sheep grazing management in the mountain region of Serra da Estrela, Portugal. Sheep farming is vitally important in these regions and relevant for sustaining their environment, biodiversity, and culture. Section 2 discusses growth and carcass yield, which are relevant characteristics for meat production. It is true that the carcass yield varies with the animal's growth. If the animal expresses most of its genetic potential and increases its average daily weight gain, it reaches its slaughter weight earlier and is more likely to generate profits for the producer. The chapter uses an example in Ethiopia to illustrate how to improve the growth and yield of sheep carcasses. In addition, the chapter presents a case of using computed tomography and thermography to diagnose respiratory disorders in sheep. The production of these small ruminants can be improved or made more efficient using new technologies, leading to precision zootechnics. The use of these technologies is not intended only for intensive systems; in fact, there are many and varied examples of the use of new technologies in extensive systems improving production and the quality of life of farmers.

António Monteiro

Agrarian School of Polytechnic Institute of Viseu,

Viseu, Portugal 

Section 1

Feeding Sheep 



\title{
Sheep Digestive Physiology and Constituents of Feeds
}

\author{
Samir Medjekal and Mouloud Ghadbane
}

\begin{abstract}
Sheep have a gastrointestinal tract similar to that of other ruminants. Their stomach is made up of four digestive organs: the rumen, the reticulum, the omasum and the abomasum. The rumen plays a role in storing ingested foods, which are fermented by a complex anaerobic rumen microbiota population with different types of interactions, positive or negative, that can occur between their microbial populations. Sheep feeding is largely based on the use of natural or cultivated fodder, which is exploited in green by grazing during the growth period of the grass and in the form of fodder preserved during the winter period. Ruminant foods are essentially of plant origin, and their constituents belong to two types of structures: intracellular constituents and cell wall components. Cellular carbohydrates play a role of metabolites or energy reserves; soluble carbohydrates account for less than $10 \%$ dry matter (DM) of foods. The plant cell wall is multi-layered and consists of primary wall and secondary wall. Fundamentally, the walls are deposited at an early stage of growth. A central blade forms the common boundary layer between two adjacent cells and occupies the location of the cell plate. Most of the plant cell walls consist of polysaccharides (cellulose, hemicellulose and pectic substances) and lignin, these constituents being highly polymerized, as well as proteins and tannins.
\end{abstract}

Keywords: cell wall, rumen microbiota, sheep feeding, tannins

\section{Introduction}

Food is, in general, one of the main factors affecting animal production. Its effects can be noted on both the quantity and quality of animal products. Although this idea is easily accepted by technicians and breeders, especially aware of the negative effects of poor, inadequate or unbalanced nutrition. Ruminant farming depends mainly on the availability and the quality of the fodder. In developing countries, the low forage potential, linked to the limitation of water and arable area, has great difficulties in producing sufficient high-quality animal protein for the human population and involves a massive use of imports of animal products such as dairy and meat products [1].

Herbivores, and especially ruminants, occupy a prominent place in the world, among domestic animals bred for production. Their contribution to satisfying humanity's food needs through the milk and meat they are made to produce is of paramount importance. Ruminant animals have the advantage over monogastric animals of being able to extract and use the energy contained in a plant biomass which cannot be used directly by man because of its high lignocellulose content. As such, ruminant animals cannot be regarded as a direct competitor of man to his food biomass [2]. 
Ruminants counting the sheep are mammals that are able to procure nutrients from plant-based food by fermenting it in a specialized stomach earlier to digestion, principally through microbial actions. The process, which takes place in the front part of the digestive system and therefore is called foregut fermentation, typically requires the fermented ingesta (known as cud) to be regurgitated and chewed again. The process of rechewing the cud to further break down plant matter and stimulate digestion is called rumination. The digestive system of the ruminant may be considered sterile at birth. Colonization of the digestive tract, particularly of the rumen, will occur gradually with the successive installation of different populations of microorganisms in a well-defined order [3]. As the ecosystem develops, it becomes more complex until it reaches a state of dynamic equilibrium. This is a state for which the ecosystem is able to self-regulate to maintain its functions by constantly adjusting microbial populations, an ecosystem which cannot be stable [4].

A single food is usually insufficient to cover the nutritional needs of the animal; hence, there is a need to combine several foods within a ration. The lambs are fed with green fodder or preserved fodder: hay, straw and corn silage. Their complementary food is, in most cases, cereals, with dehydrated soybean seed called soybean meal, a food that is very rich in protein. All foods consist of water, minerals, carbohydrates, fat and nitrogen. Livestock rations contain approximately $70-80 \%$ carbohydrates [5], mainly in the form of starch, cellulose and hemicellulose. As a result, carbohydrates provide on average nearly three-quarters of the food energy of farm animals. Two broad categories of carbohydrates are distinguished according to their location in the plant cell: cytoplasmic (or intracellular) and parietal.

\section{Anatomy of the digestive tract of the sheep}

Sheep have a digestive tract similar to that of other ruminants; its length of 22-43 $\mathrm{m}$ is comparable to that of the goats [6]. The stomach of sheep consists of four digestive organs: the rumen, the reticulum, the omasum and the abomasum (Figure 1). The rumen is the first digestive organ. It occupies the left part of the abdomen and is the largest of the gastric reservoirs [7]. It contains $70-75 \%$ of the total contents of the digestive tract, representing $50-60 \%$ of its volume [8]. The wall of the rumen consists of a muscular tunic which constitutes the bulk of its mass. Its inner surface consists of a horny epithelium, bristled with papillae of varying shapes and dimensions that play an important role in the absorption of products resulting from the metabolism of rumen microorganisms: volatile fatty acids (VFA) and ammonia. Rumen is an excellent reservoir for fermentation; it has anaerobic conditions where most food components are degraded by an extremely abundant and diversified microflora [9]. The reticulum can be compared to junction where the particles that enter and leave the rumen are sorted. It is composed of a reticulated mucosa containing also absorbent papillae. Its main function is to ensure the circulation of particles: it is from the reticulum that the contractions start, which ensure the motor skills of all gastric containers. Food remains in the rumen until it is small enough $(\leq 1 \mathrm{~mm})$ to pass through the reticulo-omasal orifice [10]. This is why the rumen and the reticulum are considered as a single organ, called reticulo-rumen. The partially fermented food then passes into the omasum which is a smaller organ than the rumen and larger than the reticulum. The omasum is a spherical organ made up of many mucous lamellae, similar to the leaves of a book, hence its name. These strips, arranged parallel to the passage of food, ensure the filtration of food particles and absorb water and minerals from the digestive content, before their arrival in the abomasum [11]. The abomasum is the only secretory reservoir. It is lined with a glandular mucosa 


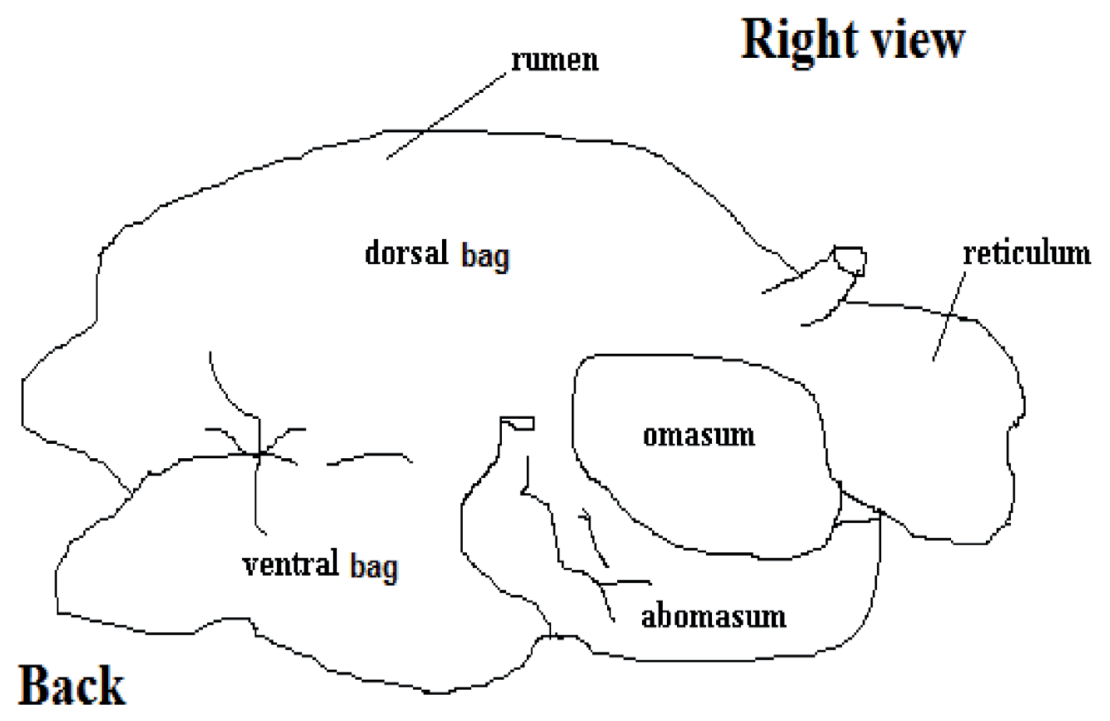

Figure 1.

Diagram of part of the ruminant digestive tract [7].

similar to that of the monogastric stomach. It consists of secreting cells that produce mucus, hydrochloric acid ( $\mathrm{pH}: 2-3)$ and pepsin.

\section{Digestive tract physiology}

\subsection{Physico-chemical conditions in the rumen}

The most favorable conditions for microbial fermentations are found in the rumen and reticulum. It presents itself as the richest and the most complex microbial ecosystem. Rumen is considered to be analogous to a reactor operating continuously with anaerobic microorganisms. It is characterized by the following physico-chemical conditions: the average temperature of the digests in the rumen is constant; it oscillates between 39 and $40^{\circ} \mathrm{C}$, and it can reach $41^{\circ} \mathrm{C}$ during intense fermentations [12]. It is estimated that the average $\mathrm{pH}$ during a day ranges from approximately 6.25 to 6.8 [13]. But a rapid fermentation can lower the $\mathrm{pH}$ to less than 5 , after consuming a rapidly fermentable carbohydrate-rich diet. The $\mathrm{pH}$ is generally regulated by saliva, which contains sodium bicarbonate and phosphate salts that buffer the acidity of the rumen at a near-neutral value. The amount of ammonia in the rumen must exceed a critical threshold for a significant portion of the day to ensure a high rate of microbial growth and digestion and hence a significant feed intake. The amount of ammonia needed to optimize the population of microorganisms in the rumen requires an advantageous protein/energy ratio in the absorbed nutrients and is variable according to the diet. In general, for feedbased diets, the ammonia content must be greater than $200 \mathrm{mg}$ of nitrogen per litre [14]. During ruminal fermentation, the population of microorganisms (especially bacteria) ferments carbohydrates and produces energy, gases $\left(\mathrm{CH}_{4}, \mathrm{CO}_{2}, \mathrm{H}_{2}\right)$, heat and organic acids. The authors reported concentrations of 74.7, 9.4, 6.5, 5.3, 3.4 and 1.3 (m.mol/l), respectively, for acetate, propionate, butyrate, isobutyrate, valerate and isovalerate [15]. The concentrations of VFA in the rumen change differently depending on the experiment. These different developments could be explained by the essential role of the mucosa in the absorption of VFAs and by the rate at which 
the rumen is emptied. The degradation in the rumen of the various substrates and in particular of soluble sugars by the ruminal microflora is accompanied by a strong gas production. The average composition of the gas pool is $60-65 \% \mathrm{CO}_{2}, 25-30 \%$ $\mathrm{CH}_{4}, 6-9 \% \mathrm{~N}_{2}, 0.3-0.6 \% \mathrm{O}_{2}, 0.1-0.3 \% \mathrm{H}_{2}$ and $0.001 \% \mathrm{H}_{2} \mathrm{~S}$ [16]. Gases thus produced in the rumen are largely eliminated by eructation, ensured by the contractions of the rumen, the frequency of which increases with the pressure exerted on the wall.

\subsection{The ruminal microbiome}

Rumen is a strictly anaerobic ecosystem, where most of the components of lignocellulosic foods are degraded and fermented by an extremely abundant and diverse microflora and microfauna. This microbial population represents more than 350 species of bacteria, fungi and protozoa. The rumen contains a high density of bacteria $\left(10^{11} / \mathrm{ml}\right)$; this bacterial flora is the most effective for digesting cellulose. Almost all ruminal cellulolysis is based on the activity of cellulolytic bacteria [17]. The main bacterial cellulolytic species of the rumen are Fibrobacter succinogenes, Ruminococcus flavefaciens and Ruminococcus albus [18]. Cellulolytic bacteria appear in the rumen 3 to 4 days after the birth of the animal, while this organ is not yet functional. Their implantation is therefore not conditioned by the consumption of solid foods. Hemicellulolytic flora in the rumen is more widely distributed among bacterial flora than cellulolytic one [19]. A distinction must be made between three categories of hemicellulolytic bacteria: the first is composed of species with depolymerase activity and glycosidic activity, able to hydrolyse the main chain and cut the lateral chains of hemicelluloses, while using oligosaccharides and released monosaccharides. In the second category, species such as Fibrobacter succinogenes, for example, have depolymerase activity but are unable to use hemicellulose hydrolysis products. The third category has different glycosidic activities and can use hydrolysis products but has no depolymerase activity. Rumen contains $10^{6} / \mathrm{m}$ of ciliated protozoa [20]. These are microscopic unicellular eukaryotic organisms, usually asexual. However, examples of conjugation with exchange of nuclear material between protozoan cells have been reported [21]. The contribution of the ciliated protozoa to the digestion of cellulose in the rumen is uncertain, due to the impossibility of obtaining them in axenic cultures. But ciliates also contribute to digestion in the rumen by degrading cellulose and vegetable starch [20]. Other ciliated species are also known as cellulolytic, but they have no indication of the extent of their activity. Highly cellulolytic ciliated protozoa include Eudiplodinium maggii, Epidinium ecaudatum, Ostracodinium bovis, Orphryscolex caudatus and Polyplastron multivisiculatum. Diplodinium pentacanthum is considered to be weakly cellulolytic. Defaunated sheep shows that the presence of protozoa in the rumen usually leads to better degradation of hemicelluloses and cellulose, when animals receive a feed-based diet, whereas with soluble carbohydrate-rich diets, the presence of these microorganisms is considered rather harmful to the animal [22]. Physiological studies show that the availability of microbial proteins for digestion is higher in defoliated ruminants than in protozoan-bearing ruminants [22]. Some species of fungus have been isolated from the rumen, but their function in the digestive ecosystem is little known and has been the subject of only rare studies. In adult ruminants, they are much more numerous in animals receiving a feed ration. In pure culture, fungi are able to solubilize a large part of plant walls, fodder, wheat straw and even more lignified fabrics such as wood [23]. With the exception of some strains of Caecomyces communis, all anaerobic fungi in the rumen are cellulolytic, and their cellulases are among the most active ones described so far. In addition, fungi appear to be able to solubilize in vitro a small part of the lignin of lignocellulose parietals but do not use this compound as a source of energy [24]. 
Bacteriophages are parasitic agents of bacteria. They are widespread in the rumen where they can eventually cause lysis of host bacteria. But their role in the food cycle and their presence in the rumen are not well known. However, the size of this population of microorganisms suggests that they are responsible for large bacterial lyses which can be a factor reducing the efficiency of food use [25].

\subsection{Digestion and metabolism in the rumen}

All rumen microbes are involved in the degradation of plant cell walls. These are degraded by the combined action of bacteria, fungi and protozoa. It is estimated that bacteria and fungi contribute approximately $80 \%$ of degradation activity and protozoa 20\% [26]. Fibrolytic bacteria such as Fibrobacter succinogenes, Ruminococcus flavefaciens and Ruminococcus albus are generally considered to be the primary microorganisms responsible for the degradation of plant cell walls in the rumen. Digestion in the rumen requires microorganisms to break through resistant wall barriers and must first adhere to food particles. Plant fragments that enter the rumen at meals are quickly colonized by bacteria, fungi and protozoa. Their adhesion capacity increases their time of presence in the rumen and makes their action more effective by concentrating hydrolytic enzymes on the target tissues [27]. Attachment of rumen microorganisms to substrates is a prerequisite for digestion of food particles. Colonization and mode of attack are specific for each microbial species. Bacteria often colonize digestible tissues through stomata, lenticels or

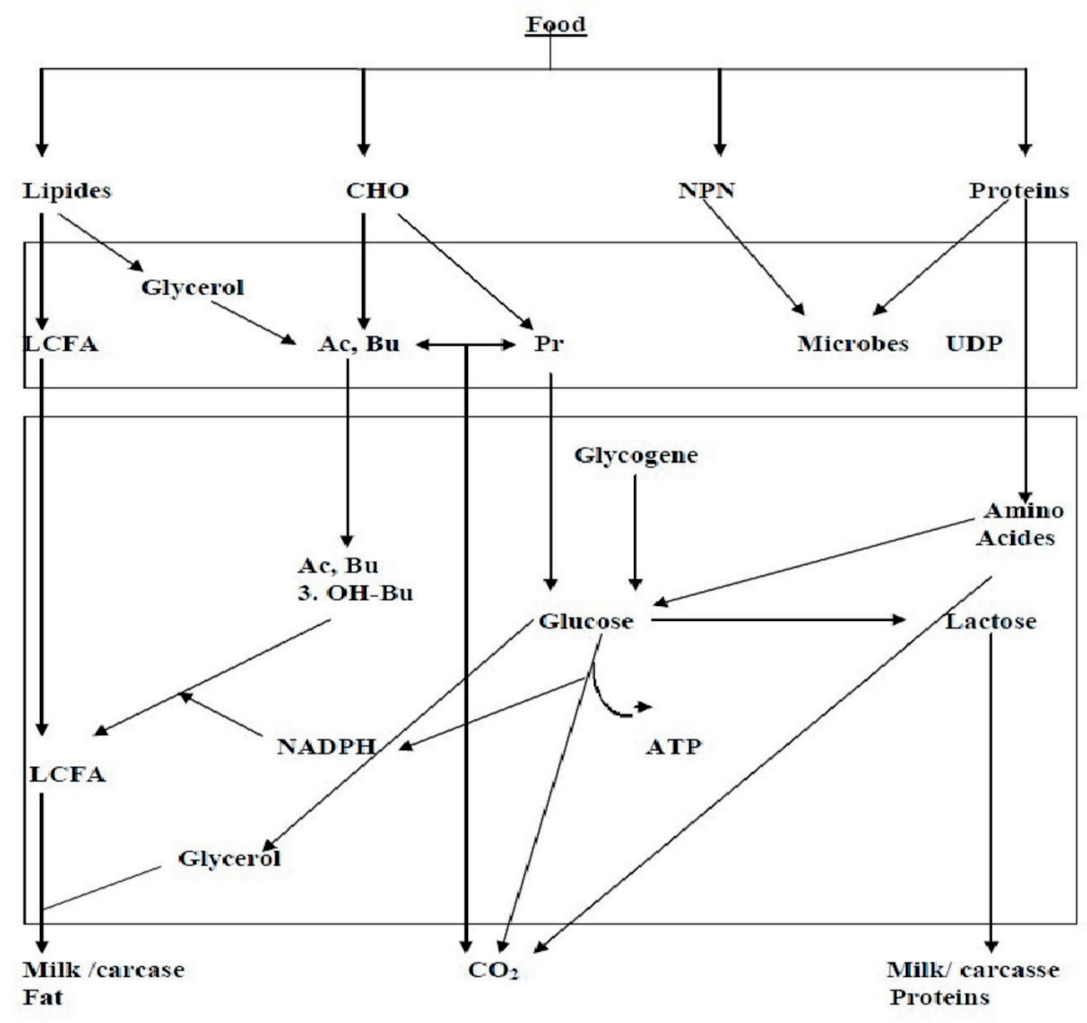

CHO: Carbohydrates; NPN: Non Protein Nitrogen; LCFA : Long Chain Fatty Acids ; Ac : Acetate ; Bu : Butyrate; Pr : Propionate; UDP : Uridine Diphosphate ;

Figure 2.

Summary of digestion and metabolism of nutrient compounds (1). CHO, carbohydrates; NPN, non-protein nitrogen; LCFA, long-chain fatty acids; Ac, acetate; Bu, butyrate; Pr, propionate; UDP, uridine diphosphate. 
damaged surfaces, and digestion takes place mainly from the inside to the outside of the colonized tissues. Rumen fungi also degrade the vulnerable surfaces of the plant and have, in addition, the ability to penetrate the cuticle of plants [28]. The association of protozoa with food particles is essential for their maintenance in the rumen, since their duration of division (25-35 hours) is on average higher than that of the small particles and the liquid phase in the rumen. This behaviour would explain the active role of ciliates in food degradation [29]. The integration of ruminal and tissue metabolism in feed degradation by ruminants is illustrated in Figure 2.

\section{Sheep feed}

The feeding of sheep is largely based on the use of natural or cultivated fodder, which is cultivated in green by grazing during the growing season of the grass, and in the form of fodder preserved during the winter period. Sheep feeding stuffs are mainly of plant origin, and their constituents belong to two types of structure: intracellular components and cell wall constituents.

\subsection{Intracellular components}

Cellular carbohydrates act as metabolites or energy reserves; soluble carbohydrates account for less than $10 \%$ of dry matter (DM) in foods, with the exception of some young grasses, beets (about 2/3 DM) and molasses (about 45\% DM).

Starches are present in the form of granules of varying size, mainly in seeds and their by-products as well as in tubers. Nitrogenous materials account for 5-60\% of the DM of food and are mainly proteins but also polypeptides of reduced size, free amino acids and amides. Fats represent only 2-5\% (apart from oilseeds and certain by-products, brewing grains, tomatoes, etc.), of which about half is in the form of fatty acids. These fatty acids are generally much unsaturated, with in particular high proportions of linoleic and linolenic acids [30].

\subsection{Cell walls}

Cell walls account for $15-90 \%$ of DM in food (15-45\% for concentrated food, $30-80 \%$ for fodder and 60-90\% for straw and certain seed husks) [31]. The plant cell wall consists of primary wall and secondary wall. Basically, the walls are deposited at an early stage of growth. A central blade forms the common boundary layer between two adjacent cells and occupies the location of the cell plate. The contiguous cells are linked together by deposition of lignin in the central blade. Most of the plant cell walls consist of polysaccharides (cellulose, hemicelluloses and pectic substances) and lignin, these constituents being strongly polymerized, as well as proteins and tannins. Typically, the polysaccharides of the plant cell wall are grouped into three fractions: (a) cellulose, the compound most resistant to chemical rupture; (b) hemicelluloses, extracted by relatively strong alkaline solution or by mild acid hydrolysis; and (c) pectic polysaccharides, extracted by hot water [32].

\subsubsection{Cellulose}

Cellulose is the most abundant polysaccharide in nature, accounting for $20-40 \%$ of the DM of all higher plants. It consists of glucose units bound in $\beta-(1-4)$ based on the replication of cellobiose units arranged in parallel (Figure 3 ). The microfibrils of celluloses are linked to each other and to hemicellulose polymers by hydrogen bonds, but there is no evidence of covalent bonds between cellulose and other plant wall components [33]. 


\subsubsection{Hemicelluloses}

The term hemicelluloses is applied to polysaccharides of the plant cell wall which are in close association with cellulose, especially in lignified tissues. The structure of hemicelluloses is more complex since it contains both pentoses (arabinose, xylose), hexoses (glucose, mannose, galactose) and uronic acids (127) (Figure 4). The digestibility of hemicelluloses is strongly related to that of cellulose and negatively correlated with lignification, since hemicelluloses are strongly associated with lignin [34].

\subsubsection{The pectic components}

The pectic polysaccharides represent approximately $35 \%$ of the plant cell wall; they are located in particular in the central blade. In dicotyledons they are formed mainly of galactosyluronic acid, while monocotyledons appear to contain a minor portion of these polysaccharides. Other major polysaccharides are also among the components of pectins such as rhamnose, arabinose and galactose [32] (Figure 5).

\subsubsection{Lignin}

Lignin, another compound of the plant cell wall, is generally a limiting factor in the degradation of plant walls in the rumen. It is formed by the polymerization of three aromatic monomers. Lignin is not hydrolysed by bacterial enzymes. But it can be degraded by oxidation by nitrobenzene or by acidolysis in dioxane with hydrochloric acid or permanganate. It permeates the cellulosic net, prevents the adhesion of microbes to membranes and is a real physical barrier for the enzymes involved in the degradation of carbohydrate polymers [35]. The bonds between lignin compounds and hemicelluloses and arabinose units also inhibit the degradation of some of the cellulose and hemicelluloses. Lignin composition, structure and content

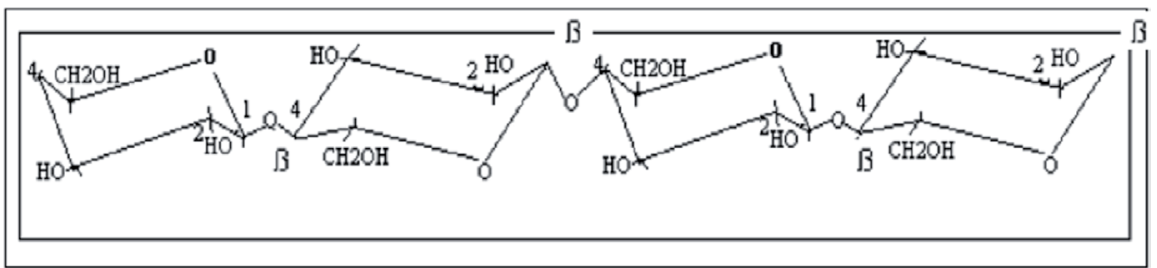

Figure 3.

Structure of cellulose (1).

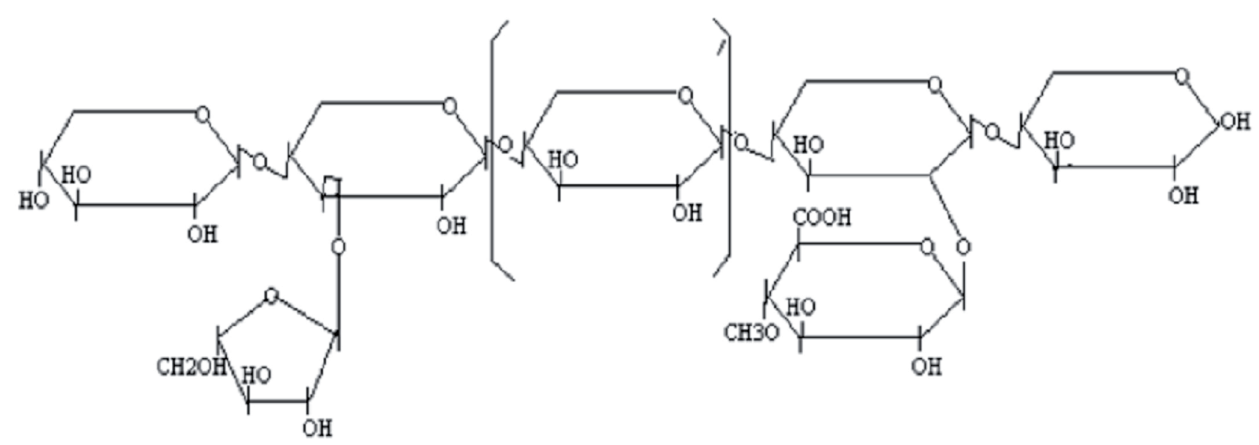

Figure 4.

Structure of hemicellulose (1). 


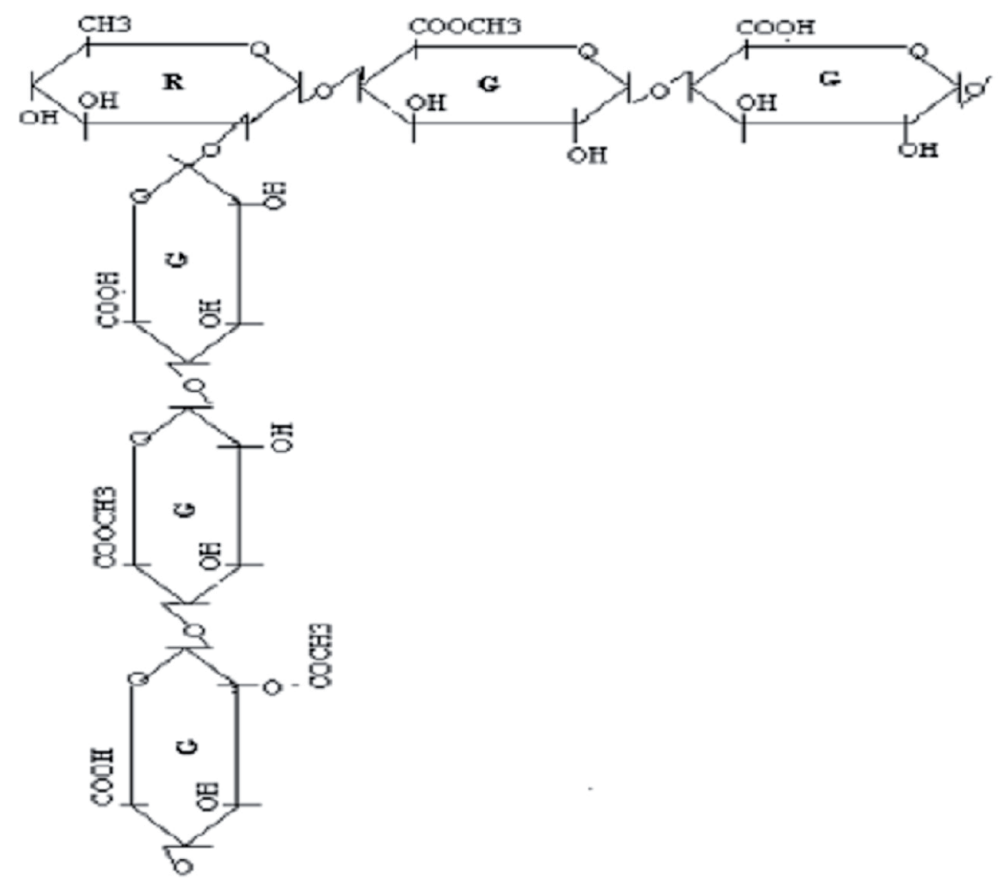

Figure 5.

Structure of pectin (1).

vary with tissues, organs, botanical origin, plant growth stage and environmental factors. The maturity of fodder plants is a determining factor in their lignin content. But for the same stage of maturity, vegetables are richer in lignin than herbs [34].

\subsubsection{Proteins}

Proteins are minor compounds of the plant cell wall. Three main classes of parietal proteins are distinguished: glycerin-rich proteins, proline-rich proteins and hydroxyproline-rich glycoproteins (exp: extensins). Peptide chains can be networked by ether bonds between two tyrosine molecules [36].

\subsubsection{Tannins}

Tannins are concentrated in the vacuoles of the plant cell [37]. They are composed of high molecular weight polyphenols (MM 500-3000). Their presence in trees, wooded shrubs and food products gives a bitter taste that can affect the animal's appetite and voluntary intake. Tannins can be divided into condensed tannins and water-soluble tannins. Condensed tannins (proanthocyanidins) are distributed in the broadest vesicles of the plant, while water-soluble tannins are restricted to dicotyledonous angiosperms which usually contain glucose as the central nucleus. Tannins affect grazing behaviour and therefore depress forage uptake in sheep [38].

\section{Conclusion}

Sheep have a gastrointestinal tract similar to that of other ruminants. The rumen plays a role in storing ingested foods, which are fermented by a complex anaerobic rumen microbiota population with different types of interactions. Sheep feeding is 
largely based on the use of natural or cultivated fodder, which is exploited in green by grazing during the growth period of the grass and in the form of fodder preserved during the winter period. Cellular carbohydrates play a role of metabolites or energy reserves; soluble carbohydrates account for less than $10 \%$ dry matter of foods, and the plant cell wall consists of primary wall and secondary wall.

\section{Conflict of interest}

The authors declare no conflict of interest.

\section{Author details}

Samir Medjekal* and Mouloud Ghadbane

Faculty of Sciences, Department of Biochemistry and Microbiology, University Mohamed Boudiaf of M'sila, Algeria

*Address all correspondence to: samir.medjekal@univ-msila.dz

\section{IntechOpen}

(C) 2020 The Author(s). Licensee IntechOpen. This chapter is distributed under the terms of the Creative Commons Attribution License (http://creativecommons.org/licenses/ by/3.0), which permits unrestricted use, distribution, and reproduction in any medium, provided the original work is properly cited. (cc) BY 


\section{References}

[1] Medjekal S. Effet de la saison de collecte sur la valeur nutritive, la production de méthane et de tannins condensés d'arbustes fourragers locaux. Essai de contrôle in vitro de la méthanogénèse ruminale d'ovins par l'utilisation de plantes médicinales [thesis]. Constantine: Mentouri Canstantine University; 2016

[2] Barone R. Appareil digestif, Appareil respiratoire. Splanchologie I. Tome 3. In: Barone R, editor. Anatomie Comparée des Mammifères Domestiques. 2nd ed. Paris: Vigot; 1984. pp. 333-379

[3] Krause DO, Smith WJ, Ryan FM, Mackie RI, McSweeney CS. Use of 16S-rRNA based techniques to investigate the ecological succession of microbial populations in the immature lamb rumen: Tracking of a specific strain of inoculated Ruminococcus and interactions with other microbial populations In Vivo. Microbial Ecology. 1999;38(4):365-376. DOI: $10.1007 / \mathrm{s} 002489901006$

[4] Lévêque C. Ecologie. De l'écosystème à la biosphère. Masson Sciences. Paris: Dunod; 2001. p. 502

[5] Hvelplund T. Volatile fatty acids and protein production in the rumen. In: Jouany JP, editor. Rumen Microbial Metabolism and Ruminant Digestion. 1st ed. Paris: INRA; 1991. pp. 165-178

[6] Devendra C. The digestive efficiency of goats. World Review of Animal Production. 1978;14:9-22

[7] Château NG, Larpent JP, Castellanos MI, Larpent JL. Les Probiotiques En Alimentation Animal Et Humaine. Paris, France: Tec. \& Doc., Lavoisier; 1994. p. 192

[8] Soltner D. Alimentation des animauxdomestiques. Collection: Sciences et Techniques Agricoles. 20th ed. Paris; 1994
[9] Fonty G, Jouany JP, Forano E, Gouet $\mathrm{P}$. Lécosystème microbien du réticulo-rumen. In: Jarrige $\mathrm{R}$, Ruckebusch Y, Demarquilly C, Farce MH, Journet M, editors. Nutrition des Ruminants Domestiques -Ingestion et Digestion. Paris: INRA Éditions; 1995. pp. 299-347

[10] Gülter H. Physiologie des Animaux Domestiques. Paris: Vigot; 1975. p. 272

[11] Ushida K, Tanaka H, Kojima Y. A simple in situ method for estimating fungal population size in the rumen. Letters in Applied Microbiology. 1989;9:109-111. DOI: 10.1111/j.1472765X.1989.tb00302.x

[12] Hungate RE. The Rumen and Its Microbes. New York. London: Academic Press; 1966. p. 533

[13] Sauffrant WB. Effect of dietary fiber on ileal digestibility and endogenous nitrogen losses in bigs. Animal Feed Science and Technology. 2001;90:93-102. DOI: 10.1016/ S0377-8401(01)00199-7

\section{[14] Satter LD, Slyter LL. Effect of} ammonia concentration on rumen microbial protein production in vitro. The British Journal of Nutrition. 1974;32:194-208. DOI: 10.1079/ BJN19740073

[15] Lindella RN, Lewis H. Intake, digestion and rumen parameters of goats fed mature veld hay ground with deep litter poultry manure and supplemented with graded levels of polymanaged groundnut hay. Livestock Research for Rural Development. 1995;6(3):35-52

[16] Engelhardt WV, Lechner-Doll M, Heller R, Schwartz HJ, Ernest WC, Ernest WC. Utilisation of agricultural waste production in animal nutrition. 
Animal Resources Development. 1987;25:56-69

[17] Bernard JK. In vitro mixed ruminal micro-organisms fermentation of whole cotton seed, coated with gelatinized corn starch and urea. Journal of Dairy Science. 2001;84(1):154-158. DOI: 10.3168/jds.S0022-0302(01)74464-5

[18] Stewart CS, Hj F, Bryant MP. The rumen bacteria. In: Hobson PN, Stewart CS, editors. The Rumen Microbial Ecosystem. London: Blackie Academic and Professional; 1997. pp. $10-72$

[19] Dehority BA. Microbial ecology of cell wall fermentation. In: Jung HG, Buxton DR, Hatfield RD, Ralph J, editors. Forage Cell Wall Structure and Digestibility. Madison: ASA-CSSASSSA; 1993. pp. 425-453

[20] Richard D, Anseline B, Baehr JC, Chaffard J, Mereaux J, Perilleux E, et al. Physiologie des Animaux. Physiologie Cellulaire et Fonctions de Nutrition. Paris: Nathan; 1997. p. 352

[21] Silanicove N, Giloba N, Perevolotsky A, Nitsan Z. Effect of daily supplementation of plyethylene glycol on intake and digestion of tannins containing leaves (Quercus calliprions, Pistacia lenticus and Ceretonia siliqua) by goats. Journal of Agricultural and Food Chemistry. 1996;44:199-274. DOI: 10.10 21/jf950189b

[22] Jouany JP, Ushida K. Plant cell wall degradation by rumen protozoa. In: Prins RA, Stewart CS, editors. Microorganisms in Ruminant Digestion. Nottingham: Nottingham University Press; 1994. pp. 69-78

[23] Joblin KN, Naylor GE. Fermentation of wood by rumen anaerobic fungi. FEMS Microbiology Letters. 1989;65(1-2):119-122

[24] Fonty G, Joblin KN. Rumen anaerobic fungi: Their role and interactions with other rumen micro-organisms in relation to fiber digestion. In: Tsuda T, Sasaki Y, Kawashima R, editors. Physiological Aspects of Digestion and Metabolism in Ruminants. San Diego: Academic Press; 1991. pp. 655-679

[25] Ritchie AE, Robinson IM, Alison MJ. Rumen bactériophage: Survey of morphological types. In: Favard P, editor. Microscopie électronique. Vol. 3. Paris: Société Francaise de Microscopie Electronique; 1970. pp. 333-334

[26] Dijkstra J. Tamminga s: Simulation of the effects of diet on the contribution of rumen protozoa to degradation of fibre in the rumen. The British Journal of Nutrition. 1995;74:617-634. DOI: 10.1079/bjn19950166

[27] Fonty J, Forano E. Ecologie de la dégradation et de la fermentation des polyosides constitutifs des parois végétales dans le rumen. Cahiers Agricultures. 1999;8(1):21-35

[28] Gabriella AV, Eric SK. Microbial and animal limitations to fiber digestion and utilisation. The Journal of Nutrition. 1997;127:819S-823S. DOI: 10.1093/ jn/127.5.819S

[29] Williams AG, Coleman CS. The Rumen Protozoa. New York: SpringerVerlag; 1991. p. 423

[30] Sauvant D. Compositions et analyses des aliments. In: Alimentation des bovins, ovins et caprins. Paris: INRA; 1988. pp. 305-314

[31] Grenet E, Demarquilly C. Rappels sur la digestion des fourrages dans le rumen (parois) et ses conséquences. In: Demarquilly C, editor. Les Fourrages Secs: Récolte, Traitement, Utilisation. Paris: INRA; 1987. pp. 142-160

[32] Dey PM, Brinson K. Plant cell walls. Advances in Carbohydrate Chemistry 
and Biochemistry. 1984;42:265-382.

DOI: 10.1016/S0065-2318(08)60127-4

[33] Morrison IM. Carbohydrate chemistry and rumen digestion. The Nutrition Society. 1979;38:269-274

[34] Jouany JP. Defaunation of the rumen. In: Jouany JP, editor. Rumen Microbial Metabolism and Ruminant Digestion. Paris: INRA Éditions; 1991. pp. 239-261

[35] Grenet E, Bestle JM. Microbes and fiber degradation. In: Jouany JP, editor. Rumen Microbial Metabolism and Ruminants Digestion. Paris: INRA; 1991. pp. 107-129

[36] Cassab CI, Varner JE. Cell wall proteins. Annual Review of Plant Physiology and Plant Molecular Biology. 1988;39:321-353

[37] Jung HJG, Fahey GCJR. Interactions among phenolic monomers and in vitro fermentation. Journal of Dairy Science. 1983, 1983;66:1255-1265. DOI: $10.3168 /$ jds.S0022-0302(83)81932-8

[38] Cope WA, Burns JC. Component of forage quality in sericea lespedeza in relation to strain, season, and cutting treatments. Agronomy Journal. 1974;66:389-394. DOI: 10.2134/agronj 1974.00021962006600030016x 


\title{
Sheep Grazing Management in the Mountain Region: Serra da Estrela, Portugal
}

\author{
António Monteiro, José Costa, Fernando Esteves \\ and Sérgio Santos
}

\begin{abstract}
Semi-natural Mediterranean pastures are an important resource in traditional systems of land use, namely in the Serra da Estrela region, located in the centre of mainland Portugal, where livestock activity is performed, mostly based in the dairy sheep farming. It is a region of rugged and mountainous relief, composed of shrub and herbaceous strata, usually associated with the sheep diet while they are grazing. These pastures take on some typologies, mainly in the mountain areas, including meadows, mesophille perennial Nardus grasslands and other perennial pastures of high ecological and scenic value. The floristic composition is predominantly composed of grasses (Poaceae), and legume (Fabaceae) species. The implementation of adequate cultivation techniques for the pasture management allows an increase in its productivity and nutritional value, resulting in increased stocking rate and reduced supplementation needs. In addition, these techniques promote the maintenance of biodiversity and landscape mosaic supporting the environment programmatic indications of the Common Agricultural Policy. Thus, the characteristics, potentialities and management practices of grasslands in the Serra da Estrela region are described, based on a literature review. This chapter aims to provide useful information, to the farmers who intend to make their pastures management more efficient while promoting environmental sustainability.
\end{abstract}

Keywords: Serra da Estrela region, sheep farming, perennial pastures, grazing management, nutritional value, sustainability

\section{Introduction}

In the central region of mainland Portugal, mainly in the valleys embedded in the Serra da Estrela massif [1], the traditional management of native dairy sheep (Figure 1) based on the use of natural and semi-natural grasslands, gives their products a strong identity and an appreciable quality, while contributing to regional development and the conservation of valuable mountain ecosystems.

Serra da Estrela is a region of rugged and mountainous relief [2], composed of shrub and herbaceous strata, with peculiar soil-climatic conditions [3]. It is 


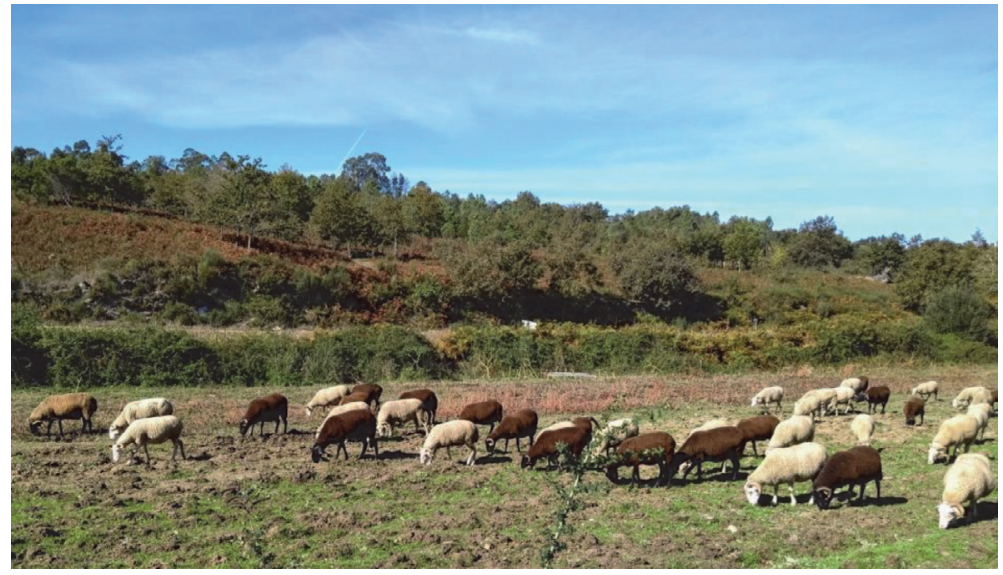

Figure 1.

Native breed of dairy sheep "Bordaleira serra da Estrela" grazing.

characterized by hot and dry summers, generally cold and long winters and with some inter-annual and inter-monthly precipitation irregularity [4]. The soils are mostly of granite or schist origin, with low $\mathrm{pH}$ and low fertility, especially based on low organic matter levels [2].

The main types of herbaceous formations that occur in Serra da Estrela mountain grasslands include permanent semi-natural meadows ("lameiros"), mesophille perennial Nardus grasslands, available in areas of higher altitude and high oligotrophy and other perennial pastures of high ecological and scenic value [5].

Permanent semi-natural meadows play an important role in the feed regime of dairy sheep while they are grazing. Lameiros are usually characterized by their water availability [6] and for their grazing management regime as pasture, forage and hay meadows, where Poaceae and Fabaceae species of some nutritional value predominate, namely, Dactylis glomerata, Lolium perenne, Festuca arundinacea, Holcus lanatus, Trifolium pratense and Trifolium repens, tolerant to soil and climatic conditions [7].

The management of these meadows consists of grazing throughout the year, except in the spring to allow a cut for hay production, being the feeding basis of the native breeds [8]. It is precisely the alternation of cutting with grazing, as well as the practice of cleaning and meticulous distribution of irrigation water, that has contributed to its maintenance and sustainability [7]. However, the trend towards depopulation of mountain regions, coupled with a scenario of increasing limitation of water resources, may endanger the sustainability of semi-natural mountain grasslands.

Beyond its economic relevance for livestock grazing and hay production, it is of huge interest to emphasize the great importance of mountain meadows for the essential services they perform, such as soil improvement and conservation, increased infiltration, drainage and water availability, soil protection against erosion and carbon sequestration [9]. Besides that, meadows are recognized as a protected habitat particularly of rare plant and fauna species and contribute to the beauty of the landscape mosaic [10].

Thus, the attributes, potential and practices of pasture management in Serra da Estrela are described, based on a bibliographic review. This chapter aims to provide useful information, especially for farmers who want to make pasture management more efficient and promote environmental sustainability in this region. 


\section{Geomorphologic and climatic characteristics of the Serra da Estrela mountain}

Serra da Estrela is the highest mountain massif in mainland Portugal ( $40^{\circ} 20^{\prime} \mathrm{N}$, $7^{\circ} 35^{\prime}$ W, $1993 \mathrm{~m} \mathrm{ASL}$ ) and is part of the Iberian Central Cordillera [1]. It is covered by a biogeographical unit known as the Estrelensean Sector (Carpetan-Leonese subprovince) [4] aligned in a NE-SW direction (Figure 2) [1]. Its relief is characterized by the widespread occurrence of uplifted planation surfaces, the majority of which are between 600 and $900 \mathrm{~m}$ in altitude, dissected by deep river valleys, sometimes interrupted by larger tectonic basins [2].

Acid $^{1}$ and phosphorus-poor palaeozoic schists intruded by variscan granitoids are the prevailing lithological types in Serra da Estrela mountain [2]. Phytogeographic elements suggest that the Serra da Estrela is in the transition between the Mediterranean and Atlantic influence [4]. Its very particular geographical position, in conjunction with the territory orography, influences the local climate characteristics and allows the existence of several bioclimatic stages [3].

Despite widespread perceptions of more recent changes in climate behavior patterns, the warmest month is July and the coldest is January. The average annual temperature is lower than $7^{\circ} \mathrm{C}$ mostly in the plateau areas [12].

During the summer, there are usually periods of a few consecutive days with high temperatures. Climate data show that it has been a trend towards an increasing frequency of days with very high temperatures, as well as the occurrence of several heat waves in last years [13].

Average precipitation values vary between $1000 \mathrm{~mm}$ in the territories of the Mondego valley, Seia and Gouveia and values above $2500 \mathrm{~mm}$ per year at the highest altitudes of the central plateau. Despite its irregular pattern, rainfall occurs mainly between November and March [14]. The western side of the mountain presents a larger number of days with rainfall, but a slightly lower total amount than the eastern part, which in turn shows a smaller number of days with rain [15]. There is a large snowfall irregularity and rarely lasts more than a few weeks per year, especially below $1700 \mathrm{~m}$. Wind regimes are complex and show large spatial variations. The more frequent directions are west and northwest [16].

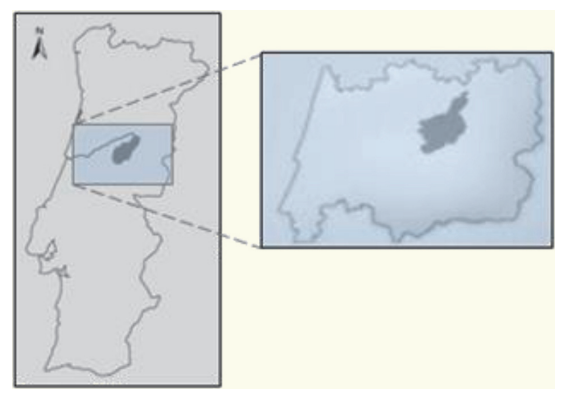

Figure 2.

Geographic location of mountain region-Serra da Estrela, Portugal.

\footnotetext{
${ }^{1}$ Soil acidity, which is frequent in mountainous regions, is one of the main limiting factors in the development of altitude pastures. The accentuated acidity is mainly due to the constant base washing of the soil profile as a result of the high levels of precipitation associated with the relief effect [11].
} 


\section{Grasslands in Serra da Estrela mountain region}

Mountain grasslands are semi-natural permanent meadows dominated by spontaneous or sub-spontaneous herbaceous plants, with the predominance of poaceae species $[7,17]$. They are typified by extensive farming using traditional breeds of sheep [9] and represent a valuable resource in the livestock farming activity of the region [5]. Their management is very different due to the high species richness and heterogeneous locations [18]. Semi-natural grasslands require continued grazing and/or mowing for their maintenance $[9,19]$ and have a relatively low productivity compared with intensively managed grasslands [20]. Their productivity is low, but they offer a number of services valued by society [21].

In fact, mountain grasslands of Serra da Estrela (Figure 3) are an important aspect of landscape and management and of great ecological value $[5,18]$, being part of the most protected ecosystem in Europe. They are recognized as key habitats for maintaining biodiversity in agricultural landscapes [20] and also an extremely important carbon store [22].

Mountain pastures on private land are often subject to mixed use of mowing and trampling. Mowing is important for getting hay in late spring or early summer depending on its location [7, 17]. In territories above $1000 \mathrm{~m}$ altitude and generally in Common lands (Baldios), pastures are used only for grazing, in many cases just in the summer season, with lower intensities of use and, consequently, with invasion of shrub species [21].

Mountain meadows growth is strongly conditioned by environmental conditions, in particular by altitude, slope, exposure, soil and inter-annual climate variation, and also due to the management conditions, such as irrigation, fertilization and utilization management (grazing and mowing) [7].

The main types of herbaceous formations that occur in Serra da Estrela mountain grasslands include permanent semi-natural meadows ("lameiros"), mesophille perennial Nardus grasslands and other perennial pastures, which will be described below [5].

\subsection{Mountain semi-natural meadows ("lameiros") and its floristic composition}

Mountain semi-natural meadows ("lameiros") are one of the most characteristic elements of the mountain landscapes of northern and central Portugal [10], namely in the Serra da Estrela, dominated by complexes of spontaneous and sub-

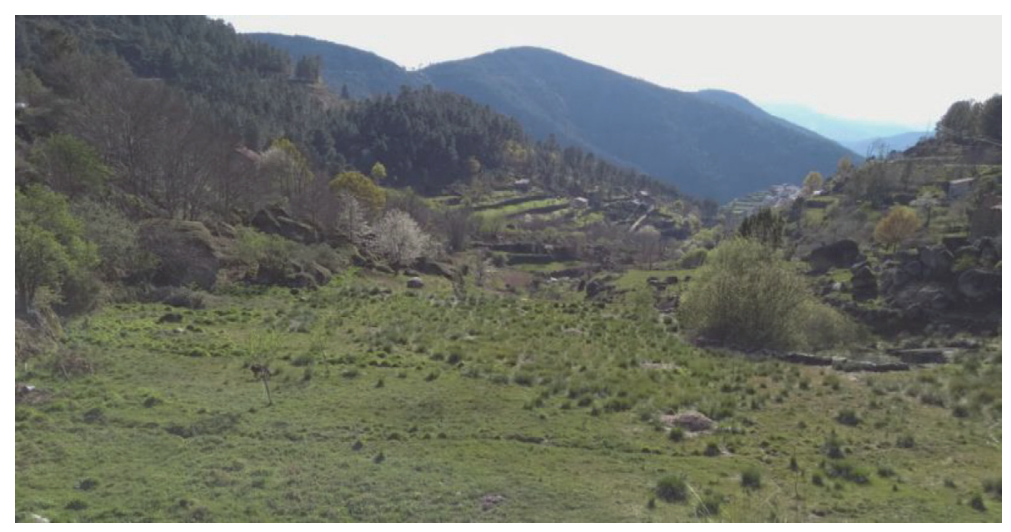

Figure 3.

Mountain grasslands in Louriga, Serra da Estrela. 
spontaneous herbaceous vegetation whose composition varies in place and time as a function of soil and climatic conditions and the duration and grazing or mowing intensity, chemical or organic fertilization or the irrigation system [23].

They are usually found in places with good water availability and fine-textured soils with high levels of organic matter [6]. Mountain meadows are not a result of deliberate sowing of improved species and are not subjected to practices such as pesticide application or soil tillage [7].

"Lameiros" are usually characterized by their water availability, as irrigated meadows located along permanent watercourses, imperfect irrigated meadows when located along non-permanent or reduced low-flow watercourses and non-irrigated meadows (or lameiros de secadal), next to temporary watercourses without water for irrigation and usually located on the highest altitude plateaus [7, 17].

The grazing management regime in the meadows is generally characterized as:

- Pasture meadows, also known as "pastigueiros," whenever its production is used exclusively for grazing $[7,17]$. They occupy non-irrigated plateau areas, therefore are less productive, but can sustain livestock during spring and early summer [24];

- Forage meadows, usually irrigated at least for some part of the year, are more productive than "pastigueiros" and made up of a larger number of nutritious species. They are also used in a mixed regime (mowing and grazing), excluding grazing in the spring [24] so that the grass grows and can be cut for hay in early summer to be reserved for consumption during the following winter $[7,17]$.

- Hay meadows, also known as "segadeiros" or cutting meadows, are the most productive pastures, irrigated all year round, fertilized and cut exclusively during the summer, and the grass is immediately consumed by the animals $[7,17,24]$.

In meadows with a large animal density, the replacement of Juncus effusus and J. acutiflorus with J. inflexus is often observed, accompanied by several other nitrophilic species such as Agrostis stolonifera, Potentilla reptans, Mentha suaveolens and Ranunculus repens. In fact, these are low-yielding species, produce poor-quality hay and avoided by ruminants. The most productive and palatable species include Holcus lanatus, Cynosurus cristatus, Festuca arundinacea subsp. arundinacea, Plantago lanceolata, Trifolium pratense and T. repens (Table 1). The drier parts of the meadows often show an impoverished community of Arrhenatherum elatius subsp. bulbosum or communities of Agrostis castellana in even drier soils [23].

Beyond its economic relevance for livestock grazing and hay production, meadows are recognized as a protected habitat particularly of rare plant and fauna species. "Lameiros" also contribute to the beauty of the landscape mosaic, thus with impacts on tourism, particularly relative to nature trails [10].

\subsubsection{Meadows management: cultural practices}

\subsubsection{Grazing and grass/hay management}

Sheep grazing controls the development of various herbaceous species on the meadows, acting as an agent for the pasture maintenance $[25,26]$. Grazing occurs in spring due to the higher precocity of its vegetative development in relation to the 


\begin{tabular}{|c|c|c|c|c|c|}
\hline \multicolumn{6}{|c|}{ Types of mountain semi-natural meadows } \\
\hline & $\begin{array}{l}\text { Irrigated } \\
\text { meadows }\end{array}$ & $\begin{array}{l}\text { Imperfect irrigated } \\
\text { meadows }\end{array}$ & $\begin{array}{l}\text { Non-irrigated } \\
\text { meadows }\end{array}$ & $\begin{array}{l}\text { Pasture } \\
\text { meadows }\end{array}$ & Hay meadows \\
\hline \multirow[t]{8}{*}{ Species } & $\begin{array}{l}\text { Holcus } \\
\text { lanatus }\end{array}$ & \multirow{8}{*}{$\begin{array}{l}\text { Floristic composition } \\
\text { close to irrigated or } \\
\text { non-irrigated meadows, } \\
\text { depending on the greater } \\
\text { or lesser availability of } \\
\text { water }\end{array}$} & $\begin{array}{l}\text { Agrostis } \\
\text { castellana }\end{array}$ & Rumex crispus & Lolium perenne \\
\hline & $\begin{array}{l}\text { Plantago } \\
\text { lanceolata }\end{array}$ & & $\begin{array}{l}\text { Agrostis } x \\
\text { fouilladei }\end{array}$ & $\begin{array}{l}\text { Rumex } \\
\text { obtusifolius }\end{array}$ & $\begin{array}{l}\text { Dactylis } \\
\text { glomerata }\end{array}$ \\
\hline & $\begin{array}{l}\text { Cynosurus } \\
\text { cristatus }\end{array}$ & & $\begin{array}{l}\text { Trifolium } \\
\text { dubium }\end{array}$ & $\begin{array}{l}\text { Rumex } \\
\text { conglomeratus }\end{array}$ & Trifolium repens \\
\hline & $\begin{array}{l}\text { Hypochaeris } \\
\text { radicata }\end{array}$ & & $\begin{array}{l}\text { Gaudinia } \\
\text { fragilis }\end{array}$ & $\begin{array}{l}\text { Mentha } \\
\text { suaveolens }\end{array}$ & $\begin{array}{l}\text { Trifolium } \\
\text { pratense }\end{array}$ \\
\hline & Poa trivialis & & \multirow{4}{*}{$\begin{array}{l}\text { Arrhenatherum } \\
\text { elatius subsp. } \\
\text { bulbosum }\end{array}$} & \multirow{2}{*}{$\begin{array}{l}\text { Brachypodium } \\
\text { rupestre }\end{array}$} & Holcus lanatus \\
\hline & $\begin{array}{l}\text { Dactylis } \\
\text { glomerata }\end{array}$ & & & & $\begin{array}{l}\text { Ranunculus } \\
\text { repens }\end{array}$ \\
\hline & $\begin{array}{l}\text { Trifolium } \\
\text { pratense }\end{array}$ & & & & $\begin{array}{l}\text { Plantago } \\
\text { lanceolata }\end{array}$ \\
\hline & $\begin{array}{l}\text { Trifolium } \\
\text { repens }\end{array}$ & & & & $\begin{array}{l}\text { Glyceria } \\
\text { declinata }\end{array}$ \\
\hline Notes & & & & $\begin{array}{l}\text { Abundance } \\
\text { of species } \\
\text { rejected by } \\
\text { animals }\end{array}$ & $\begin{array}{l}\text { Have the } \\
\text { largest } \\
\text { amounts of } \\
\text { plants of great } \\
\text { nutritional } \\
\text { value }\end{array}$ \\
\hline
\end{tabular}

Table 1.

Floristic composition in meadows with different water and use regimes-Adapted from [7].

common lands ("baldios"), thus ensuring an adequate transition between feeding of herds with hay in winter and with grazing the common lands in the summer.

When the grass is ready to be grazed in the common lands, access to the meadows is limited in order to allow the development of the vegetation to obtain hay [8]. Hay cutting time should coincide as closely as possible with the dominant grass spike in the meadows to obtain hay with good nutritional value [7].

When the common lands vegetation becomes scarce and very dry in the late summer and, at the same time, there occurs the regrowth of vegetation in the meadows after hay cutting, grazing is allowed again until mid or late autumn [8] depending on the environmental and growing conditions of the grass [21].

The absence of the flocks grazing results in loss of biodiversity, due to changes in vegetation development [25]. Similarly, hay cutting also acts as a maintenance agent favouring the development of the most desirable plants and the persistence of rare plant species. Haying has a very positive effect on yield, both on hay and pasture, which is less significant with late haying [17].

\subsubsection{Water regime}

Irrigation is practised in meadows throughout the year whenever water is available although its functionality changes seasonally. During the summer (usually, July to September), it aims to meet the water needs of vegetation and, during the winter period, provides a favourable thermal balance at the grass's micro-climate level ("lima" watering) [24]. 
The meadows irrigation is made by surface run-off using a system in which the run-off water concentrated in water lines is diverted to small slope channels from where it flows over the permanent pastures [24, 27, 28].

Water flowing over pasture is a traditional practice of winter irrigation made by a continuous flowing of a thin layer of water ("lima") covering the entire soil surface, to prevent frost damage [29] and to allow the rapid resumption of vegetation development during the spring [30]. Especially at night, irrigation water is relatively hotter than soil, pasture and air temperature, so the effect of frost is attenuated [31].

If water availability is not enough to guarantee this kind of irrigation for a relatively long period of frost, it is preferable to not irrigate, so as to avoid freezing of water in the soil upper layers causing damages to the plants root system, a phenomenon that is locally referred to as "descalçamento" [24].

\subsubsection{Fertilization}

Fertilizer application is a cultural technique with a positive effect on hay and pasture productivity $[29,30]$. Studies by several authors show the positive effect of this cultural technique on the mountain meadows yield [30, 32, 33].

Traditional fertilization relies essentially on grazing animal waste and run-off "waters" from where they occur. Animal droppings are the main source of nutrients in mountain pastures and can reach $100 \mathrm{~kg}$ of nitrogen, $90 \mathrm{~kg}$ of potassium and $9 \mathrm{~kg}$ of phosphorus per hectare in 365 days of grazing [7].

Nitrogen fertilizers are indicated as those that lead to greater production increases and contribute more to the evolution of pasture composition, with repercussions on dry matter (DM) production [7].

\subsubsection{Weed control}

In meadows, the main problems with weeds are fetuses, brambles and other weeds rejected by grazing animals (low-palatability plants).

These weeds' incidence is generally associated with poor management of grass use. Its control is generally made by means of a cleaning cut which, at the same time, enhances the growth of more palatable species, correcting or nullifying the effects of a less efficient use [7]. Controlled fire use is used as a cleaning technique in the continuous weed patches.

The clearing of furrows, waterline banks is also a cultural operation with a positive effect on the meadows productivity, as it favors the conditions for water conduction and, consequently, the homogeneity of its distribution. This operation is normally carried out during the winter period by farmers and shepherds [34].

\subsubsection{Pasture yield}

The practice of rotational and rationed grazing by conditioning the number of grazing animals, per unit area and grazing time, avoids the under-utilization of "lameiros" in summer, resorting to the use of fences or regular displacement of animals between plots [7].

The yields can vary from 4 to 6 tons of dry matter (DM) per hectare (ha) per year, up to 12 tons DM/ha/year, which corresponds, respectively, to less than 1 livestock unit (LSU)/ha and more than 2 LSU/ha [7].

These differences in pasture production are related to the availability of water, the type of vegetation, the irrigation management and also the geographical 
location. The best returns and economic results are obtained when a community management is adopted as opposed to the individual management of semi-natural meadows [35].

\subsection{Cervunais and other perennial pastures}

\subsubsection{Cervunais}

This particular ecosystem in Serra da Estrela, named "cervunal," is characterized by the dominance of Nardus stricta L. (Poaceae), and involves 10.000 ha of a biogenetic reservation (DL n ${ }^{\circ} 140 / 99,24$ th April-Appendix B-1, 6230) within the Natural Park of Serra da Estrela (NPSE) [36].

Cervunais occur in areas of higher altitude (above $1600 \mathrm{~m}$ ) and high oligotrophy. They are well adapted to winter cold and also to poor, acidic, often moist and poorly drained soils and are usually grazed by sheep and not submitted to mowing [5]. Due to their late development, Cervunais are an important resource for sheep feeding during late spring/early summer, playing an important role in the local economy, often arising from the Serra da Estrela cheese production system [37].

Their maintenance is clearly dependent on the correct management of grazing, which is fundamental in controlling invasion by woody species. At present, grazing management is in decline and the woody species are invading some of the grassland. The greater amount of combustible material in the woody plants has the potential to increase the temperature of fires to damaging levels, even in wet areas, compared to the fires by shepherds on the grasslands [36].

Fire represents the main threat to the conservation of this type of grasslands and is associated with inadequate practices of land management and planning [38]. Severe fires over the last decade have transformed the high-altitude grassland biogenetic reserve in the Natural Park of Estrela Mountain (NPSE) of Portugal. The most remarkable change in the herbaceous vegetation after fire was the abrupt increase of Festuca trichophylla in the burnt area, to the detriment and abrupt decrease of Nardus stricta [36].

\subsubsection{Other permanent highland pastures}

Lowland hay meadows (Alopecurus pratensis, Sanguisorba officinalis) are made up of tall grass, associated with deep and well-drained soil. Their maintenance promotes the infiltration of water in the soil, the regulation of nutrient levels, the lack of continuity of the forest mosaic and, consequently, the prevention of forest fires. These grasslands are dominated by the species Arrhenatherum elatius subsp. bulbosum, Agrostis castellana or Festuca rothmaleri [39].

Molinia meadows are associated with calcareous, peaty and loamy soils (Molinion caeruleae), including the juncal and juncal-meadows, dominated by Juncus effusus and/or Juncus acutiflorus which develop in deep and acidic soils conserving moisture during almost the whole year. They are usually near water lines, occupying the territory of riparian forests. Juncal and juncal-meadows are not fertilized and have reduced feed value for sheep [40].

Pseudo-steppe with grasses and annuals of the Thero-Brachypodietea are distinguished by the occupation of deep, well-drained, oligotrophic soils, including communities dominated by Agrostis castellana, which are frequent in non-irrigated meadows [41]. They also include perennial grasslands, usually dominated by heliophilous grasses such as Arrhenatherum elatius subsp. baeticum, Agrostis castellana, Celtica gigantea and Festuca elegans [38]. 


\section{Grassland species management, chemical and nutritive values}

\subsection{Dactylis glomerata}

On established pastures, cocksfoot (Dactylis glomerata) initiates growth early in the spring. Grazing should begin when growth reaches approximately $20 \mathrm{~cm}$. A 28to 35-day recovery period is recommended [41].

Winter grazing should be limited to $60 \%$ of annual growth. Autumn to early winter is the preferred time for sowing. Spring sowing may be an option in higher altitude areas, or areas with more reliable rainfall over late spring and summer [42].

Cocksfoot is capable of moderate to high levels of herbage production in wellmanaged, regularly fertilized pastures. Growth rates of $60-80 \mathrm{~kg} \mathrm{DM} / \mathrm{ha} /$ day are possible in autumn and spring under conditions of good moisture and temperature. In winter, production will commonly range from 5 to $20 \mathrm{~kg} \mathrm{DM} / \mathrm{ha} /$ day. The actual amount of herbage produced will be influenced by many factors, including altitude, soil texture, soil moisture and temperature [42].

The protein content declines with maturity. This high protein content is balanced by a fiber content that is often higher than that of other grasses (ryegrass and fescue) at the same stage of maturity [43].

Cocksfoot is highly palatable to livestock especially in the early part of the growing season [41] (Table 2).

\subsection{Festuca arundinacea}

Festuca arundinacea (tall fescue) is a perennial plant with large size and well adapted to a wide range of climates. Tolerant of various soil types, it has a better yield on deep and fertile soils. It is not compatible with ryegrass (Lolium spp.). Sowing is done in the fall, usually mixed with lucerne in irrigated meadows. Seed establishment is slow and grassland has a weak initial development [45]. It can be used for direct grazing, mowing, hay production, hay silage or silage. Growth begins in early spring and grazing should begin after the plants are at least $15 \mathrm{~cm}$ tall. The height of the stubble should be kept at $10 \mathrm{~cm}$. Regrowth is favourable in cool spring and fall weather. The recommended rest period between grazing cycles is approximately $21-28$ days. Frequent spring grazing cycles when plants are in the vegetative stage will help reduce alkaloid concentrations in animal diets if there is a symbiotic relation with endophyte organisms [41].

Tall fescue has high digestibility at the appearance of the first year and provides good-quality biomass with $14-15 \%$ protein content in dry matter [41] (Table 3).

\begin{tabular}{|c|c|c|c|c|c|c|c|c|c|c|c|c|}
\hline \multirow[b]{2}{*}{ Herbage } & \multirow[b]{2}{*}{$\begin{array}{l}\text { DM (\% } \\
\text { as fed) }\end{array}$} & \multicolumn{6}{|c|}{ Composition (\% DM) } & \multicolumn{5}{|c|}{ Nutritive value } \\
\hline & & $\mathrm{CP}$ & $\mathrm{CF}$ & NDF & ADF & Lignin & Ash & $\begin{array}{c}\text { OMD } \\
(\%)\end{array}$ & $\begin{array}{l}\text { ED } \\
(\%)\end{array}$ & $\begin{array}{l}\mathrm{DE}(\mathrm{MJ} / \\
\mathrm{kg} \mathrm{DM})\end{array}$ & $\begin{array}{l}\text { ME (MJ/ } \\
\text { kg DM) }\end{array}$ & $\begin{array}{l}\text { ND } \\
(\%)\end{array}$ \\
\hline Fresh & 20.7 & 16.3 & 29.7 & 59.9 & 32.3 & 4.5 & 9.7 & 69.4 & 66.3 & 12.0 & 9.5 & 58.9 \\
\hline Dried & 89.1 & 13.1 & 30.2 & 63.7 & 36.5 & 4.5 & 8.7 & 65.1 & 61.5 & 11.1 & 8.9 & 57.7 \\
\hline \multicolumn{13}{|c|}{$\begin{array}{l}\text { DM: Dry matter; CP: Crude protein; CF: Crude fiber; NDF: Neutral detergent fiber; ADF: Acid detergent fiber; } \\
\text { OMD: Organic matter digestibility; ED: Energy digestibility; DE: Digestible energy; ME: Metabolizable energy; ND } \\
\text { Nitrogen digestibility. }\end{array}$} \\
\hline
\end{tabular}

Table 2.

Chemical composition and nutritive value of cocksfoot (Dactylis glomerata) [44]. 


\begin{tabular}{lcccccccc}
\hline \multicolumn{10}{c}{ Composition (\% DM) } \\
\hline Phenology & DM (\%) & CP & CF & NDF & ADF & NDF & Ash & OM \\
\hline Early flowering & 83.4 & 15.0 & 30.7 & 65.1 & 39.9 & 4.6 & - & 83.4 \\
\hline $\begin{array}{l}\text { DM: Dry matter; CP: Crude protein; CF: Crude fiber; NDF: Neutral detergent fiber; } \\
\text { OM: Organic matter. }\end{array}$
\end{tabular}

Table 3.

Chemical composition of tall fescue (Festuca arundinacea) [46].

\begin{tabular}{lcccccccc}
\hline \multicolumn{7}{c}{ Composition (\% DM) } \\
\hline Phenology & DM (\%) & CP & CF & NDF & ADF & NDF & Ash & OM \\
\hline Spikelet & 21.0 & 15.0 & 26.8 & 56.8 & 30.2 & 3.8 & - & 84.7 \\
\hline Hay & 80.0 & 22.1 & 19.6 & 41.9 & 29.6 & 4.9 & - & 91.6 \\
\hline $\begin{array}{l}\text { DM: Dry matter; CP: Crude protein; CF: Crude fiber; NDF: Neutral detergent fiber; ADF: Acid detergent fiber; } \\
\text { OM: Organic matter. }\end{array}$
\end{tabular}

Table 4.

Chemical composition of perennial ryegrass (Lolium perenne L.) $[46,47]$.

\subsection{Lolium perenne $\mathrm{L}$.}

Lolium perenne L. (perennial ryegrass) (Table 4) is better adapted to the temperate climate of the Atlantic than to hot summers as they slow down its growth. It also prefers fertile, heavy and moist soil, slightly acidic $\mathrm{pH}$-demanding in nitrogen.

Sowing is preferably made in the fall, with fast seed germination and crop establishment. It has regeneration speed and resistance to trampling. It can be mixed with red clover, white clover or hybrid ryegrass (L. perenne, L. multiflorum). Thus, when mixed with white clover, it produces about 12-14 t MS per ha/year.

Perennial ryegrass has high digestibility and protein content compared to other perennial grasses [45].

\subsection{Holcus lanatus}

Holcus lanatus occurs over a wide range of soil types, although it prefers a soil $\mathrm{pH}$ range of 5-7.5. It is found in hay meadow communities, poorly drained and waterlogged soils, and low-fertility and nutrient-rich soils, pastures and meadows. Although $H$. lanatus is adapted to growing in wet conditions, it can also survive moderate drought, but with a much reduced growth rate [48].

Normally, H. lanatus is not preferred by flocks as its hairy nature means it is less digestible than perennial ryegrass (Lolium perenne) [49]. The young shoots are promptly consumed by the flocks, the dry matter content is low, digestibility is good and the mineral composition is relatively high [48] (Table 5).

\subsection{Trifolium pratense}

Trifolium pratense (red clover) is sown in autumn or spring. It is a very productive plant, but demanding in humidity, phosphorus, potassium and other elements. It shows predominant growth in autumn-winter, is more suited to cutting than grazing, produces up to 5-6 cuts in the first year when sown in the fall and is used for mowing when pure and mainly for grazing in mixtures [45]. 


\begin{tabular}{lcccccccc}
\hline \multicolumn{7}{c}{ Composition (\% DM) } \\
\hline Phenology & DM (\%) & CP & CF & NDF & ADF & NDF & Ash & OM \\
\hline Spikelet & 28.7 & 6.3 & 34.2 & 71.5 & 41.0 & 5.6 & - & 91.1 \\
\hline $\begin{array}{l}\text { DM: Dry matter; CP: Crude protein; } \text { CF: Crude fiber; NDF: Neutral detergent fiber; } \text { ADF: Acid detergent fiber; OM: } \\
\text { Organic matter. }\end{array}$
\end{tabular}

Table 5 .

Chemical composition of Holcus lanatus [47].

Red clover should be cut for hay when no more than $50 \%$ is in flower, when it has the optimal feeding value, with more than 14-15\% protein. Mowing red clover later impairs its feeding value but also compromises the second cut, as young shoots already elongated may be removed during the first cutting [50].

Red clover is preferably grazed in spring. Grazing begins at the quarter to halfbloom stage. In spring and early summer, a rest period of 21-35 days is recommended. Regrowth is excellent in spring when temperatures are low and soil moisture is available, but poor later in the summer [41]. Its contribution to biomass production declines rapidly after the first 2-3 years under grazing [51] (Table 6).

\subsection{Trifolium repens}

White clover (Trifolium repens) is the most important forage legume for grazing, whether as a spontaneous component of natural or permanent pastures or sown in association with grasses such as perennial ryegrass (Lolium perenne) [51]. The inclusion of white clover (Figure 4) in mixed pasture (grass and legume) increases the feeding value of the pasture due to the high protein and organic matter (OM) digestibility of white clover [52].

White clover can withstand both continuous stocking and rotational grazing. In rotational grazing systems, stolons can regrow during rest periods, thereby increasing the white clover contribution to the stand. White clover cultivars should be chosen in accordance with the intended type of grazing: small leaf cultivars are best suited for continuous grazing by sheep, while large leaf types are best adapted to rotational grazing by sheep. In mixed swards, grazing should be heavy enough to prevent white clover being shaded and thus its decline [52] (Table 7).

\subsection{Plantago lanceolata}

Ribwort plantain (Plantago lanceolata) has a good production of dry matter, mainly in winter activity. In many environments, plantain produces similar amounts of perennial ryegrass fodder. A feature of plantain productivity is its rapid

\begin{tabular}{lccccccccccccc}
\hline & \multicolumn{4}{c}{ Composition (\% DM) } & \multicolumn{5}{c}{ Nutritive value } \\
\hline Herbage & $\begin{array}{l}\text { DM (\% } \\
\text { as fed) }\end{array}$ & CP & CF & NDF & ADF & Lignin & Ash & $\begin{array}{c}\text { OMD } \\
(\%)\end{array}$ & $\begin{array}{c}\text { ED } \\
(\%)\end{array}$ & $\begin{array}{c}\text { DE (MJ/ } \\
\text { kg DM) }\end{array}$ & $\begin{array}{c}\text { ME (MJ/ } \\
\text { kg DM) }\end{array}$ & $\begin{array}{l}\text { ND } \\
(\%)\end{array}$ \\
\hline Fresh & 19.0 & 19.7 & 22.4 & 36.4 & 26.6 & 4.1 & 10.4 & 74.1 & 70.9 & 13.1 & 10.4 & 73.3 \\
\hline Dried & 89.5 & 18.3 & 27.4 & 37.7 & 28.3 & 6.0 & 6.8 & 66.2 & 62.7 & 11.9 & 9.5 & 65.1 \\
\hline
\end{tabular}

DM: Dry matter; CP: Crude protein; CF: Crude fiber; NDF: Neutral detergent fiber; ADF: Acid detergent fiber; OMD: Organic matter digestibility; ED: Energy digestibility; DE: Digestible energy; ME: Metabolizable energy; ND: Nitrogen digestibility.

Table 6.

Chemical composition and nutritive value of red clover (Trifolium pratense) [50]. 


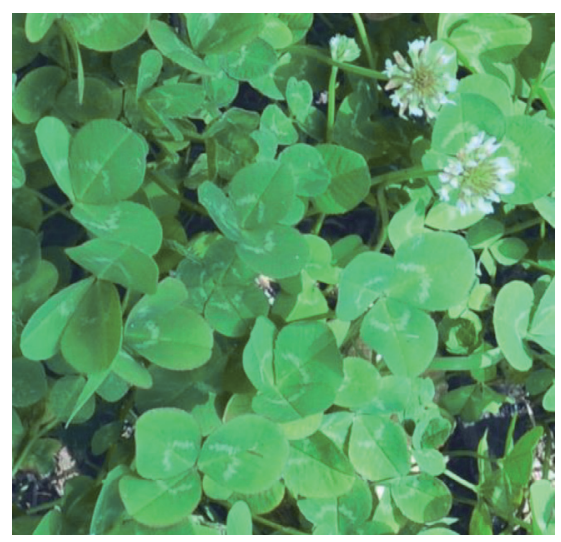

Figure 4.

White clover (Trifolium repens).

\begin{tabular}{|c|c|c|c|c|c|c|c|c|c|c|c|c|}
\hline \multirow[b]{2}{*}{ Herbage } & \multirow[b]{2}{*}{$\begin{array}{c}\text { DM } \\
\text { (\% as fed) }\end{array}$} & \multicolumn{6}{|c|}{ Composition (\% DM) } & \multicolumn{5}{|c|}{ Nutritive value } \\
\hline & & $\mathrm{CP}$ & CF & NDF & ADF & Lignin & Ash & $\begin{array}{c}\text { OMD } \\
(\%)\end{array}$ & $\begin{array}{l}\text { ED } \\
(\%)\end{array}$ & $\begin{array}{l}\mathrm{DE}(\mathrm{MJ} / \\
\mathrm{kg} \mathrm{DM})\end{array}$ & $\begin{array}{l}\text { ME (MJ/ } \\
\text { kg DM) }\end{array}$ & $\begin{array}{l}\text { ND } \\
\text { (\%) }\end{array}$ \\
\hline Fresh & 16.8 & 24.9 & 19.6 & 27.5 & 22.1 & 3.9 & 11.3 & 80.9 & 77.3 & 14.2 & 11.1 & 82.2 \\
\hline Dried & 82.7 & 22.7 & 23.4 & 29.4 & 28.8 & 3.5 & 12.3 & 65.1 & 61.6 & 10.7 & 8.4 & 69.3 \\
\hline \multicolumn{13}{|c|}{$\begin{array}{l}\text { DM: Dry matter; CP: Crude protein; CF: Crude fiber; NDF: Neutral detergent fiber; ADF: Acid detergent fiber; OMD } \\
\text { Organic matter digestibility; ED: Energy digestibility; DE: Digestible energy; ME: Metabolizable energy; ND: Nitrogen } \\
\text { digestibility. }\end{array}$} \\
\hline
\end{tabular}

Table 7.

Chemical composition and nutritive value of white clover (Trifolium repens) [53].

\begin{tabular}{lcccccccc}
\hline \multicolumn{10}{c}{ Composition (\% DM) } \\
\hline Herbage & DM (\% as fed) & CP & CF & NDF & ADF & Lignin & Ash & OM \\
\hline Aerial part & 15.7 & 20.4 & 13.6 & 41.1 & 29.3 & 13.8 & 12.4 & - \\
\hline $\begin{array}{l}\text { DM: Dry matter; CP: Crude protein; CF: Crude fiber; NDF: Neutral detergent fiber; } \text { ADF: Acid detergent fiber; OM: } \\
\text { Organic matter. }\end{array}$
\end{tabular}

Table 8 .

Chemical composition of Plantago lanceolata [55].

response to moisture in autumn and also the rapid rumen degradation rates to improve dry matter intake [54].

In sheep grazing swards of white clover, ribwort plantain is fairly palatable. It proves to be suitable in combination with grass in swards to sustain growth in finishing lambs. It may also be recommended as an alternative to hay. However, compared to chicory (Cichorium intybus), it supports less live-weight gain and lower hot carcass weights [55] (Table 8).

\section{Mountain grasslands as providers of an ecosystem service in Serra da Estrela}

The sustainability depends on the multi-functional role of farming systems. Pastures are central part of these High Natural Value (HNV) systems [56]. 
Mediterranean mountain grasslands generate high levels of biodiversity and a range of other environmental services and amenities [57].

As the total area of grasslands has declined, particularly grasslands of high biodiversity, mountain areas are now among the last refuges of High Nature Value (HNV) grassland in Europe. Many traditionally managed mountain grasslands, which have developed under centuries of livestock grazing, are still species-rich compared with lowlands [18].

Well-managed grassland is associated with environmental advantages, including soil carbon sequestration, reduced soil erosion, and maintenance of ecosystem services associated with grasslands [9]. Shrub vegetation associated with these grasslands may contribute to the retention of soil water, a reduction in run-off and diminished soil erosion. Under climate changes scenarios that predict an increased frequency of high-intensity rainfall and more events leading to downstream flooding, the positive role of grasslands in mitigating such events may increase [57]. In tests conducted in different regions of the USA, with different soils and slopes varying between 2 and $16.5 \%$, soil losses of 14.6-250.4 $\mathrm{t} \mathrm{ha}^{-1}$ year ${ }^{-1}$ were observed with monocultures of corn or cotton, while under the same conditions with pastures the losses amounted to only $0.01-0.70 \mathrm{t} \mathrm{ha}^{-1}$ year $^{-1}$ [58].

Extensive grazing is an essential tool for reducing fire risk on semi-natural pastures with shrubs and trees [21]. In the Mediterranean, grasslands have an important role in fire prevention. Rural abandonment is leading to the development and dominance of shrub formations, increasing vegetation fuel load and the hazards of fire. Frequently, extensive woodland and shrub vegetation are interrupted by areas of grassland or pasture, which act as effective barriers against propagation of wildfires. Maintenance of open grassland areas is thus essential to maintain landscape heterogeneity and a potential tool to mitigate the risks of wildfires [57]. In drier regions of Europe, and more widely with future climate change projections, wild fires will cause considerable loss of human life, environmental and property damage, and carbon release [21].

Threats are endangering the future of grasslands [59]. Although biodiversity is one of the most important ecosystem services provided by European semi-natural grasslands, agriculture remains as a driver of biodiversity loss, either through intensification and conversion of grassland to arable cropping, or land abandonment and loss of the traditional farming practices that have often generated species-rich habitats [18].

Appreciation and implementation of mechanisms for payment of environmental services, possibly similar to those already in uses in some forest land uses, may potentially contribute to the economic sustainability and future conservation of grasslands and their multifunctional role [57]. Recently, the Portuguese Carbon Fund has demonstrated interest in remunerating the farmers willing to control shrub encroachment at pastures through the use of non-invasive techniques that promote soil carbon sequestration [59].

The potential of pasture soils as carbon sinks, however, can be difficult to maintain in relation to predicted climate change scenarios, such as increased frequency of droughts and heat waves [57].

\section{Conclusions}

The sheep farming associated with permanent mountain pastures is of great significance for the sustainability and for the social and economic development of the local populations; so, the greater and better knowledge of the potential of this type of grasslands is of great relevance for the valorization of regions affected by desertification and less economically favoured. 
Semi-natural pastures are an important source of feed for sheep grazing and when harvested as hay for the winter period in Serra da Estrela mountain. Therefore, it is necessary to optimize meadow management practices in order to meet their increasing needs for quality forages, as well as the knowing of adequate nutritive value of herbage, essential for a high rate of live-weight gain and overall sheep performance. In this sense, we suggest a guidance or training programmes that should be promoted to make farmers aware of how to improve and sustain pasture productivity.

Permanent mountain pastures are also of major importance for the conservation of floristic, faunistic and landscape biodiversity and other related ecosystem services such as carbon sequestration, soil conservation or as a factor in regulating the hydrological cycle. It is important that the traditional practices and the environmental management undertaken by farmers are not endangered by a desire of other stakeholders to transform the landscape, reducing farm capital.

Due to its ecological and economic value, it is also important to ensure the maintenance and improvement of these ecosystems in order to promote or increase its biodiversity. Encouraging the development of these land use will allow activities linked to livestock production and provide different externalities and ecosystems, thus according to the environment-supporting programmatic indications of the Common Agricultural Policy.

Furthermore, studies are necessary to fully understand the ecological and economical implications of reduction and changes in mountain grasslands in the context of a future rain decrease and global warming.

Finally, new researches should be carried out, such as the integrated processing and data analysis related to animal behavior and location, together with the analysis of the nutritional value of pasture species that will allow the creation of a decision support tool in the livestock management process.

\section{Author details}

António Monteiro ${ }^{1,2 *}$, José $\operatorname{Costa}^{1}$, Fernando Esteves $^{1}$ and Sérgio Santos ${ }^{1}$

1 Agrarian Superior School, Polytechnic Institute of Viseu, Viseu, Portugal

2 CERNAS, Research Centre for Natural Resources, Environment and Society, Polytechnic Institute of Viseu, Polytechnic Campus, Viseu, Portugal

*Address all correspondence to: amonteiro@esav.ipv.pt

\section{IntechOpen}

(C) 2020 The Author(s). Licensee IntechOpen. This chapter is distributed under the terms of the Creative Commons Attribution License (http://creativecommons.org/licenses/ by/3.0), which permits unrestricted use, distribution, and reproduction in any medium, provided the original work is properly cited. (cc) BY 


\section{References}

[1] Mora C, Vieira G, Alcoforado MJ, editors. Daily Minimum Air

Temperatures in the Serra da Estrela.

Portugal Finisterra: Revista Portuguesa de Geografia; 2001. pp. 49-60. DOI: 10.18055/Finis1647

\section{[2] Aguiar C, Vila-Viçosa C. Trás-os-} Montes and Beira Alta. In: Loidi J, editor. The Vegetation of the Iberian Peninsula. Plant and Vegetation. Vol. 12. Cham, Switzerland: Springer; 2017. DOI: 10.1007/978-3-319-54784-8_9

[3] Meireles C, Mendes P, Vila-Viçosa C, Cano-Carmona E, Pinto-Gomes C. Geobotanical aspects of Cytisus oromediterraneus and Genista cinerascens in Serra da Estrela (Portugal). Plant Sociology. 2013;50(1):23-31. DOI: 10.7338/pls2013501/03

[4] Meireles C, Pinto-Gomes C, Cano E. Approach to climatophilous vegetation series of Serra da Estrela (Portugal). Acta Botanica Gallica: Botany Letters. 2012;159(3):283-287

[5] Ribeiro S, Monteiro A. Pastagens permanentes em zonas de montanha: caracterização, gestão e conservação. Revista de Ciências Agrárias. 2014; 37(1):131-140

[6] Pereira LS, Sousa VS. Lameiros e prados de lima. In: Evaluación de los Usos del Agua en Tierras Secas de Iberoamerica. Mendoza: CYTED e Inst. Argentino de Investigaciones de las Zonas Aridas; 2006. pp. 191-202

[7] Moreira N, Aguiar C, Pires JM. Lameiros e outros prados e pastagens de elevado valor florístico. In: Pastagens de Montanha. Lisboa: Direcção Geral de Desenvolvimento Rural; 2001. ISBN: 972-8693-18-4

[8] Santos J. Relatório de Investigação: Práticas pastoris, cargas pecuárias e aspectos organizativos do pastoreio:
O monte de Pitões (Relatório final). Lisboa: Departamento de Economia Agrária e Sociologia Rural. Instituto Superior de Agronomia (ISA); 1995

[9] David S, Julie W, Alice J, Neal H, Martin P. Background report on best environmental management practice for the crop and animal production sector: Preliminary findings supporting the development of an EMAS Sectoral Reference Document. RC Science for Policy Report, Publications Office of the European Union, Luxembourg. European Commission. 2014. p. 584

[10] Pôças I, Cunha M, Pereira LS. Remote sensing based indicators of changes in a mountain rural landscape of Northeast Portugal. Applied Geography. 2011;31:871-880. DOI: 10.1016/j.apgeog.2011.01.014

[11] Moreira N. O Melhoramento das Pastagens de Montanha. Vila Real: Universidade de Trás-os-Montes e Alto Douro (UTAD); 1986. p. 73

[12] Espinha Marques J, Duarte J, Constantino A, Aguiar C, Rocha F, Marques J, et al. In situ measurement of hydraulic conductivity of mountain soils: A case study in Serra da Estrela Mountain (Central Portugal). Cadernos do Laboratorio Xeolóxico de Laxe. 2009; 34:143-164

[13] Santos Silva J, Cruz V, Barbosa J. Estudo e desenvolvimento de estratégias para prevenção dos riscos associados ao clima quente, nas explorações de pequenos ruminantes, em portugal. Livro de Actas do 6.0 Seminário Internacional da Rede FAO-CIHEAM sobre Ovinos e Caprinos - Sub-Rede Sistemas de Produção DRAP-N I FAOCIHEAM. 2008;6:203-209

[14] Madureira L, Magalhães P, Gabriel Silva P, Marinho C, Oliveira R. Economia dos Serviços de Ecossistema - Um guia para conhecer e valorizar serviços de 
agroecossistemas em áreas protegidas de montanha. Quercus. 2013:146

[15] Vieira G, Jansen J, Ferreira N.

Environmental setting of the Serra da Estrela, Portugal: A short-note. Landscape ecology and management of Atlantic mountains. International Association for Landscape Ecology. 2005;12:1-10

[16] Vieira GT, Mora C. General characteristics of the climate of the Serra da Estrela. In: Glacial and Periglacial Geomorphology of the Serra da Estrela. Guidebook for the FieldTrip. IGU Commission on Climate Change and Periglacial Environments. Lisboa, Portugal: University of Lisbon; 1998. pp. 26-36

[17] Pires JM, Pinto PA, Moreira NT. Lameiros de Trás-os-Montes.

Perspectivas de futuro para estas pastagens de montanha. In: ESA. ISPB. Bragança Bragança: Instituto Politécnico de Bragança; 1994. ISBN: 972-745-025-3

[18] Hochberg H, Zopf D. Preservation of forage quality and biodiversity by utilization of mountain meadows. In: Grassland Farming and Land Management Systems in Mountainous Regions. Vol. 83. Gumpenstein, Austria: European Grassland Federation; 2015. p. 585. ISBN: 978-3-902559-65-4

[19] Darnhofer I, Schermer M, Steinbacher M, Gabillet M, Daugstad K. Preserving permanent mountain grasslands in Western Europe: Why are promising approaches not implemented more widely? Land Use Policy. 2017;68: 306-315

[20] Pykälä J. Mitigating human effects on European biodiversity through traditional animal husbandry. Conservation Biology. 2000;14(3): 705-712. DOI: $10.1046 /$ j.1523-1739.2000.99119.x

[21] Moreira N. Melhoramento das pastagens de montanha. Pastagens e Forragens. 1998;19:51-60
[22] Beaufoy G, Jones G, Kazakova Y, McGurn P, Poux X, Stefanova V. Permanent pastures and meadows under the CAP: The situation in 6 countries. The European Forum on Nature Conservation and Pastoralism (EFNCP). 2011:70

[23] Aguiar C, Vila-Viçosa C. A flora e a vegetação das montanhas de Portugal continental. In: Sustentabilidade da Montanha Portuguesa: Realidades e Desafios. Vol. 3. Bragança, Portugal: Instituto Politécnico de Bragança; 2018. pp. 59-90. ISBN: 978-972-220-0

[24] Pereira LS, Sousa VS. Lameiros e prados de lima, uma paisagem das terras altas húmidas de Portugal. In: V Seminário Internacional CYTED-XVII. Un enfoque para la gestion sustentable del agua: Experiencias en zonas humedas. Buenos Aires, Argentina: Universidad de Buenos Aires; 2005. p. 12

[25] Kumm K-I. Sustainable management of Swedish seminatural pastures with high species diversity. Journal for Nature Conservation. 2003; 11:117-125

[26] Pikälä J. Plant species responses to cattle grazing in Mesic semi-natural grassland. Agriculture, Ecosystems and Environment. 2005;108:109-117

[27] Dries A. The art of irrigation. The development, stagnation and redesign of farmer-managed irrigation systems in Northern Portugal [PhD Dissertation]. Wageningen Universiteit; 2002. p. 369

[28] Jansen J, Castro P, Costa L. Economic-Ecologic Interactions in the Serra da Estrela in Economy and Ecology of Heathlands: Heathland Ecology and Management. Vol. 42013. Zeist, Netherlands: KNNV Publishing; 2013. pp. 66-90. ISBN: 978-90-5011-4615

[29] Ferreira A, Dias-da-Silva A, Cruz M, Vieira R, Azevedo J, Sousa A. Os fenos 
do Nordeste de Portugal. Pastagens e Forragens. 1981;2:67-77

[30] Raposo J, Centeno M, Pires J, Carvalho M. Efeito da fertilização na produção de lameiros. Região Planáltica de Bragança. Pastagens e Forragens. 1990;11:41-53

[31] Gonçalves D. A rega de lima no interior de Trás-os-Montes. Vila Real: Instituto Universitário de Trás-os-Montes e Alto Douro; 1985

[32] Pires J, Centeno M, Rego C, Raposo J, Carvalho R. Efeito da fertilização na composição florística de lameiros. Pastagens e Forragens. 1990; 11:69-86

[33] Pires J, Fernandes A, Bernardo A, Pires J, Moreira N. Meadow management hay yields and nutritive value in the meditarranean mountain regions of northeast of Portugal. Sustainable grazing, nutritional utilization and quality of sheep and goat products. In: First Joint Seminar of the FAO-CIHEAM Sheep and Goat Nutrition and Mountain and Mediterranean Pastures SubNetworks. Granada (Espanha): CIHEAM; 2003. pp. 67-73

[34] Pôças I. Os lameiros no contexto das paisagens de montanha. In:

Monitorização por detecção remota em diferentes escalas espácio-temporais. Faculdade de Ciências da Universidade do Porto para obtenção do grau de Doutor em Ciências Agrárias; Porto, Portugal; 2010

[35] Santos J, Aguiar C. Private hay meadows and common pastures: Integrated management of two ecosystems. In: Environmental and Land Use Issues: An Economic Perspective. Kiel: Wissenschaftsverlag Vauk; 1995. pp. 491-501

[36] Azul A, Ramos V, Sales F. Early effects of fire on herbaceous vegetation and mycorrhizal symbiosis in high altitude grasslands of Natural Park of Estrela Mountain (PNSE). Symbiosis. 2010;52:113-123. DOI: 10.1007/ s13199-010-0103-1

[37] Sales F, Dinis A, Azul M. A Conservação dos Cervunais no Desenvolvimento Local. Coimbra: Grasses, Universidade de Coimbra; 2007. p. 11

[38] ICNF-Plano Sectorial da Rede Natura 2000. Caracterização de valores naturais. 2006c. (Cited: 2019-02-03). Available from: http://www.icnf.pt/ portal/naturaclas/rn2000/resource/rnplan set/hab/hab-6220.pdf [Accessed: 03 January 2019]

[39] ICNF - Plano Sectorial da Rede Natura 2000. Caracterização de valores naturais. 2006a. Available from: http:// www.icnf.pt/portal/naturaclas/rn2000/ resource/rn-plan-set/hab/hab-6510.pdf [Accessed: 03 January 2019]

[40] ICNF-Plano Sectorial da Rede Natura 2000. Caracterização de valores naturais. 2006b. Available from: http:// www.icnf.pt/portal/naturaclas/rn2000/ resource/rn-plan-set/hab/hab-6410.pdf [Accessed: 03 January 2019]

[41] Griggs T, Church J, Wilson R. Pasture Plant Composition and Forage Nutritional Value. Pasture and Grazing Management in the Northwest Chapter. Vol. 11. Idaho, USA: Pacific Northwest Extension Publication University of Idaho, Oregon State University, Washington State University; 2010. pp. 107-119

[42] Hackney B, Dear B. Cocksfoot NSW Department of Primary Industries Primefact. 2007. Available from: https:// www.dpi.nsw.gov.au/_data/assets/ pdf_file/0011/155486/cocksfoot.pdf

[43] INRA. Alimentation des bovins, ovins et caprins. Besoins des animaux valeurs des aliments. Tables Inra 2007. 
Editions Quae. Versailles [FRA]; 2007. p. 330. ISBN: 978-2-7592-0020-7

[44] Heuzé V, Tran G. Cocksfoot (Dactylis glomerata). Feedipedia, a programme by INRA, CIRAD, AFZ and FAO. 2015a. Available from: https:// www.feedipedia.org/node/466

[Accessed: 11 December 2019]

[45] Trigueiros J, Abreu J, Silva D. Conceitos e Práticas em Modernas Explorações Agrícolas. Alternativas Forrageiras. Porto, Portugal: SPI Sociedade Portuguesa de Inovação; 2005. pp. 19-28. ISBN: 972-8589-54-9

[46] Abreu JM, Bruno-Soares AM, Calouro F. Intake and Nutritive Value of Mediterranean Forages \& Diets. Lisboa: ISA Press; 2000. p. 46

[47] Monteiro A, Freire J, Costa J, Falcão L, Projecto VT, PRODER PA. Melhoramento de Pastagens Permanentes de Altitude. Lisboa: Instituto Superior de Agronomia (ISA); 2015. p. 125

[48] Roberts P. Holcus lanatus (common velvet grass) CABI Invasive Species Compendium. 2013. Available from: https://www.cabi.org/isc/datasheet/ 114824 [Accessed: 17 November 2019]

[49] Wilman D, Riley JA. Potential nutritive value of a wide range of grassland species. The Journal of Agricultural Science. 1993;120(1):43-49. DOI: $10.1017 /$ S0021859600073573

[50] Heuzé V, Tran G, Giger-Reverdin S, Lebas F. Red clover (Trifolium pratense). Feedipedia, a programme by INRA, CIRAD, AFZ and FAO. 2015b. Available from: https://www.feedipedia. org/node/246 [Accessed: 26 October 2015]

[51] Dewhurst RJ, Delaby L, Moloney A, Boland T, Lewis E. Nutritive value of forage legumes used for grazing and silage. Irish Journal of Agricultural and Food Research. 2009;48:167-187

[52] FAO. Grassland Index. A Searchable Catalogue of Grass and Forage Legumes. Rome, Italy: FAO; 2011. Available from: https://web.arch ive.org/web/20170120044942/http:// www.fao.org/ag/AGP/AGPC/doc/ GBASE/default.htm

[53] Heuzé V, Tran G, Hassoun P, Lebas F. White clover (Trifolium repens). Feedipedia, a programme by INRA, CIRAD, AFZ and FAO. 2019c. Available from: https://www.feedipedia.org/node/ 245 [Accssed: 10 April 2019]

[54] Judson HG, AJE M. Benefits and uses of plantain (Plantago lanceolata) cv. Ceres tonic in livestock production systems in New South Wales. In: Proceedings of the 26th Annual Conference of the Grassland Society of NSW Grassland Society of new South Wales. Vol. 26. New Wales of South, New Zeland: Grassland Society of NSW; 2011. pp. 151-152. ISBN: 9781742562131

[55] Heuzé V, Tran G. Ribwort plantain (Plantago lanceolata). Feedipedia, a programme by INRA, CIRAD, AFZ and FAO. 2015d. Available from: https:// www.feedipedia.org/node/114

[56] Sequeira EM. Pasture and fodder crop as part of high natural value farm systems at Mediterranean dry land agroecosystems. Sustainable Mediterranean grasslands and their multi-functions. Zaragoza: CIHEAM / FAO / ENMP / SPPF Options Méditerranéennes : Série A. 2008;79:17-21

[57] Bugalho MN, Abreu JMF. The multifunctional role of grasslands. Porqueddu C. (ed.). Tavares de Sousa M.M. (ed.). Sustainable Mediterranean grasslands and their multi-functions. Zaragoza: CIHEAM/ FAO/ENMP/SPPF. Options Méditerranéennes: Série A. 2008;79: 25-30 
Sheep Grazing Management in the Mountain Region: Serra da Estrela, Portugal DOI: http://dx.doi.org/10.5772/intechopen.92649

[58] NIAB. Grasses and Herbage

Legumes Variety Leaflet. Cambridge,

UK: National Institute of Agricultural

Botany (NIAB); 1998. p. 48

[59] Valada T, Teixeira R, Martin H, Ribeiro M, Domingos T. Grassland management options under Kyoto protocol article 3.4. The Portuguese case study. New approaches for grassland research in a context of climate and socio-economic changes. Zaragoza: CIHEAM, Options Méditerranéennes, Série A. 2012;102:53-56 



\title{
Sheep Feeding in the Sahel Countries of Africa
}

\author{
Hamidou Nantoumé
}

\begin{abstract}
With an area estimated to 3.053 million $\mathrm{km}^{2}$, the Sahel has a quickly growing population. According to CILSS, there will be 100 million people in the region by 2020 and 200 million by 2050, almost four times the current population. The region, frequently struck by drought and food insecurity, is one of the areas most severely affected by global climate change in the coming years. With up to $80 \%$ of its people living on less than $\$ 2$ a day, poverty is more widespread in the Sahel than in most other parts of Africa. Sheep farming is very important for the Sahel countries. It does not require a high input at its beginning, so even women and children are involved in small ruminant raising. They provide food and play important socioeconomic factors. However, productivity of livestock including the one of sheep is low. Nutrition is the most important constraint in sheep farming especially during the dry season when both availability and quality of forages are low. The most complex and limiting production factors in sheep farming for the Sahel countries are those concerning nutrition and feed supplies. The objective of this review chapter was to describe the major nutritional constraints to sheep farming systems in the Sahel countries and explore ways of overcoming the most important constraints for efficient and sustainable sheep feeding. Issues addressed in this review include causes of undernutrition and environmental implications, adaptation by sheep to it, and manipulative strategies to cope with feed scarcity in smallholder sheep farming systems.
\end{abstract}

Keywords: extensive, feeds and feeding, intensive, nutrition, Sahel, sheep

\section{Introduction}

Sheep farming is very important for the Sahel countries. It is a popular activity in which even women and children who are the lowest income owner are involved. Besides food and essential nutrients, sheep farming plays an important socioeconomic role in the ceremonies such as baptism and religious and other feasts. Sheep are important assets to the rural poor and play a critical role in both sustainability and intensification of agricultural productivity in most farming systems. Their manure helps maintain soil fertility, and they contribute to the overall farming enterprise in terms of income and employment. Sheep farming provides poor farmers with a flexible reserve and access to markets especially with sheep fattening. However, productivity of livestock including sheep is low. The lack of animal products is not due to a lack of animals per se, because Africa has $12.7 \%$ of humans, $13.6 \%$ of cattle and buffalo, $28.9 \%$ of goats, $19.2 \%$ of sheep, and $73.4 \%$ of camel 
population of the world, but due to low productivity [1]. Nutrition is the most important constraint in sheep farming. There are a number of reasons for the low productivity of which insufficient and inefficient use of feed is the major one [2].

The objective of this chapter is to review the major nutritional aspects of sheep farming in the Sahel countries of Africa. It includes a deep review of the sheep farming systems, exploring ways of overcoming the most important constraints for efficient and sustainable sheep feeding based on my own experience, and the available literature. The nutrient (water, energy, protein, minerals, and vitamins) requirements of sheep that vary greatly according to the physiological stage, maintenance, growth, gestation, lactation, fattening, were reviewed. The review covers the characteristics of the common feeds in the Sahel based on their types (roughages and concentrates), their names and classes, their chemical composition, and their nutritive value.

Practical guidelines for sustainable sheep feeding including the following important recommendations are given. During the rainy season (from July to September), forages cover the nutrient requirements for extensive sheep production system except for the lactating ewes and fattening rams. Supplemental concentrate feeds are required during the cool dry season (October to February). During the hot dry season (March to June), both forage and concentrate supplements are required. Lactating ewes and fattening rams are fed using formulated rations to meet their respective nutrient requirements. Issues addressed in the review chapter will include causes of undernutrition and environmental implications, adaptation by sheep to it, and manipulative strategies to cope with feed scarcity in smallholder sheep farming systems.

\section{Study area, Sahel defined}

The Sahel from its original Arabic name means "flat land." It includes a band of Africa indicating a floristic and climatic transition between the Sahara in the North and the Sudan savannah in the South in which rainfalls are important. Rainfalls from $200 \mathrm{~mm}$ in the North to $600 \mathrm{~mm}$ to the South are the limits of the Sahel zone in Africa [3]. This area is characterized with a monomodal distribution of rainfalls that occurs randomly in 90 to 120 days and a long dry season of 8 to 9 months [4]. This alternate of wet and dry periods rhythm and determine animal and plant productions and their modes of management.

The Sahel, in this study, not just covers the band but includes all the entire 10 countries that are Burkina Faso, Chad, Eritrea, the Gambia, Guinea-Bissau, Mali, Mauritania, Niger, Senegal, and Sudan as shown in Figure 1.

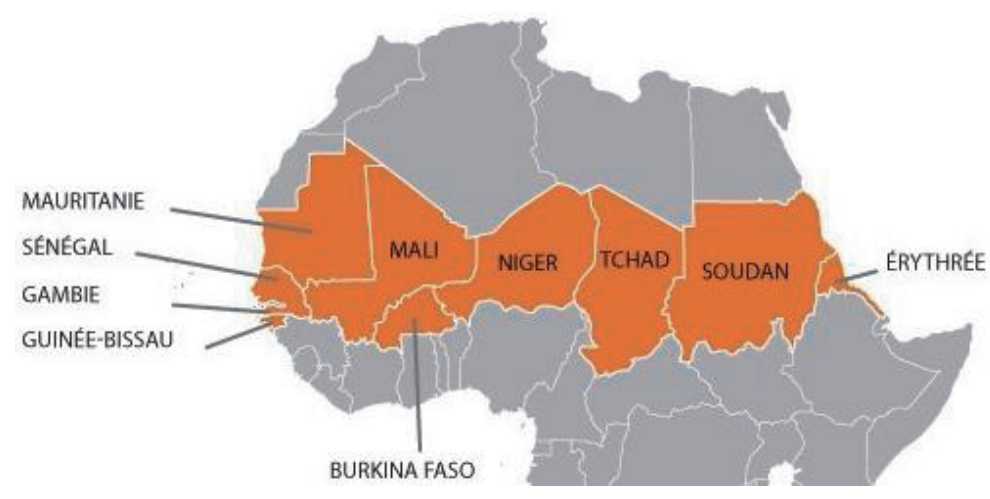

Figure 1.

Map of the Sahel countries. 


\section{Ecological zones of the Sahel countries}

The Sahel countries like Mali include four ecological zones, and characteristics of the range lands fluctuate depending on four ecological zones. The quantity and quality of feedstuffs fluctuate depending on the two seasons (dry and rainy) and the length, amount, and distribution of rainfalls and soil fertility. Sivakumar et al. [5] gave a detailed description of the ecological zones of Mali, and most of them are shared with the different zones of Sahel. The four ecological zones include:

- The arid (Sahara) zone in which the vegetation is scarce and made of herbaceous plants and thorny shrubs: the climate is tropical arid with two seasons, a rainy season of 1 to 2 months and a dry season of 10 to 11 months. The average annual rainfall is less than $200 \mathrm{~mm}$, and there is almost no growing season. Monthly average temperatures vary from $31.1^{\circ} \mathrm{C}$ in January to $42.4^{\circ} \mathrm{C}$ in May.

- The semi-arid (Sahel) zone in which the vegetation is an herbaceous stratum composed primarily of grasses and a woody stratum composed of forbs, shrubs, and trees: the climate is tropical and semi-arid with two seasons, a rainy season, hot and humid of 4 months from June to September, and a dry season of 8 months divided into a cold period from October to February and a hot period from March to May. The average annual rainfall is $580 \mathrm{~mm}$ with a growing season of 18 weeks. Monthly average temperatures vary from $39.9^{\circ} \mathrm{C}$ in May to $31.9^{\circ} \mathrm{C}$ in August.

- The sub-humid (Sudanese) zone in which the vegetation is composed of woody species and herbaceous species: the climate is tropical sub-humid (savannah) with a rainy season of 6 months and a dry season of 6 months. The average rainfall is $1037 \mathrm{~mm}$ with a growing season of 24 weeks. Monthly average temperatures vary from $30^{\circ} \mathrm{C}$ in August to $37.7^{\circ} \mathrm{C}$ in March.

- The humid (Guinean) zone in which the vegetation is composed of woody species and herbaceous species: the climate is tropical and humid with a rainy season of 7 months and a dry season of 5 months. The average rainfall is $1300 \mathrm{~mm}$ with a growing season of 40 weeks. Monthly average temperatures vary from $30^{\circ} \mathrm{C}$ in August to $37.7^{\circ} \mathrm{C}$ in March.

\section{Sheep production systems in the Sahel}

The population growth increases fast in the Sahel. According to CILSS, there will be 100 million people in the region by 2020 and 200 million by 2050; this is almost four times the actual population. More than half of them, 141 million, will live in the three countries Burkina Faso, Mali, and Niger.

Livestock remain one of the most important economic activities of the Sahel with a contribution of 30 to $40 \%$ of the agricultural GNP of the countries like Burkina Faso, Cap-Vert, Mali, Mauritania, Niger, Senegal, Soudan, and Chad [6]. Besides this economic contribution, pastoral livestock is one of the most important agricultural productions in the Sahel. The Sahelian countries have an important potential of meat production with livestock estimated in 2006 at 63 million cattle, 168 million small ruminants, and more than 6 million camels [7].

Based on the natural grazing, and some fallows, the livestock of this region is based mainly on the availability of forage that depends on climatic fluctuations, 
seasonal variations, and grazing intensity as have been demonstrated by the big droughts of years 1970 and 1980 [8]. Those droughts caused the loss of about 80\% of the livestock of the region conducting thousands of people to move out of the region [8].

However, the succession of wet years allowed a rapid numeric reconstitution of livestock [9], and in Mali, the number of small ruminants increased from 1990 to 2005 to $26 \%$ [6].

Livestock farming in general and sheep farming in particular are very important for the Sahel countries. The most complex and limiting production factors in sheep farming for the Sahel countries are those concerning nutrition and feed supplies. The traditional concept that natural pasture is free and of no value and can, therefore, be put through grazing animals at a production cost approaching zero, with all returns of net profit, is erroneous and contributes in these problems. In addition, most land is government-owned but communally utilized.

The main resources used as sheep feeds include pastures (grazing lands, crop residues, and cultivated forages), concentrate feed, household wastes, and other feed supplements. Their relative importance varies across production systems. The solution to the problem of feed supplies depends on the production system and the ecological zone [10]. Agro-ecology, seasonality, land tenure, and management practices influence feed availability. Generally, sheep are herded during the rainy season and free ranging during the dry season. Criteria as ecological zones, relationship on sheep and crop farming, and the level of importance in sheep farming activities are the basis for making typologies on the sheep farming systems. Each ecological zone and based on how sheep farming depends on it, corresponds to a standard herding practice and a dominant sheep breed. The investment done for sheep farming and the objective of production give a precision on classification within the same ecological zone.

Although there are several livestock systems [11], they can be divided into two main systems of sheep production as has been indicated by Swift et al. [12]:

- A pastoral system in which sheep farming of the range lands provides more than $50 \%$ of the feeds of sheep and provided more than $50 \%$ of the income.

- An agro-pastoral system in which sheep farming depends primarily on other feed resources and provides from 10 to $50 \%$ of the income.

Within each system, depending on the experience and investment of the farmer, there are more or less extensive sheep farming systems. Both systems (pastoral and agro-pastoral) can be divided into extensive, semi-intensive, and intensive depending on the level of input and investment as described by Sangaré [13].

\section{Characterization of sheep feeds and feeding}

Sheep feed may be defined as any dietary substance that nourishes the sheep body for maintenance, reproduction, and productions. The usual feeds are divided into two categories with entirely different characteristics: roughages and concentrates.

\subsection{Roughages}

They are feeds containing more than $18 \%$ of crude fiber [14] or more than $35 \%$ of cell wall on a dry matter basis. They are low in net energy per unit weight because 
of the high cell wall content. They include pastures, hay straw, haulms, trees, silage, etc. The pastures are used in in situ feeding on the standing herbaceous or tree/ browse plants for which quality and quantity fluctuate depending on the season and agroclimatic zones. They are most important feed resources in the Sahel. The can be cut and carried to the animal especially during the dry season. Crop residues are the second most important feed resources that can be grazed in situ or cut and carried to the animals. Their quality and quantity fluctuated depending several factors such as variety, production techniques, area planted, etc.

\subsection{Concentrates}

They include feeds with less than $18 \%$ crude fiber or less than $35 \%$ cell wall on a dry matter basis [14]. They may contain less than $20 \%$ protein on a dry matter basis and be called energy feeds and contain more than $20 \%$ protein on a dry matter basis and be known as protein supplements. The concentrate feeds include agroindustrial byproduct feeds such as rice bran, cottonseed, cottonseed meal, peanut meal, molasses, cereal grains, etc. Concentrates are expensive, are highly digestible, possess a low fiber content, and are rich in proteins. Since many concentrates are used as a staple in human diets, economics usually determine whether concentrates are fed to ruminants. Certainly few of the cereal grains are fed to sheep in the Sahel, but millet grain is known to be used by women for their "mouton de case." On the basis of protein content, concentrates may be divided into carbonaceous feeds with a relatively low protein content such as the cereal grains and nitrogenous feeds that are rich in protein such as the various oil cakes and animal byproducts.

\subsection{Feed names}

A more complex categorization using several parameters becomes necessary for an efficient use of feeds. The parameters used very often are name, class, chemical composition, and nutritive value of feeds.

A name should clearly state the source of the material and describe any process, alteration, or special circumstance, which affects the nutritional value of that feed. The International Feed Vocabulary as described by Harris et al. [15] is designed to give a comprehensive name to each feed as concisely as possible. Each feed name was coined by using descriptors taken from one or more of six facets that are origin (scientific or common name), part fed to animals, process or treatment, stage of maturity or development, cutting, and grade.

\subsection{Feed classes}

In the Sahel countries, feed classification is derived from two mean sources. Harris [16] and Harris [17] grouped feeds into eight classes based on their composition in the way they are used for formulating diets. The groups include (1) dry forages and roughages; (2) pasture, range plants, and forages fed green; (3) silages; (4) energy feeds; (5) protein supplements; (6) mineral supplements; (7) vitamin supplements; and (8) additives.

The second source for classification of feeds is that of Baumont et al. [18] from which feeds are divided into two groups that are roughages and concentrates; the roughage group includes five classes that are (1) dry forages; (2) silages; (3) hays; (4) stalks, straw, and haulms; and (5) roots and tuber. The concentrate group includes 10 classes that are (1) dehydrate feeds, (2) cereals, (3) coproducts of cereals, (4) grains, (5) cake and meals, (6) other plant products, (7) coproducts, 


\begin{tabular}{ll}
\hline $\mathbf{N}^{\circ}$ Classes & Criteria for classification \\
\hline 1. Roughages & $\begin{array}{l}\text { All the forages and rangelands, natural or cultivated and green or dry containing more than } \\
18 \% \text { of crude fiber or containing more than 35\% of NDF on a dry matter basis: straws, stalks }\end{array}$ \\
\hline 2. Silages & Include ensiled forages \\
\hline $\begin{array}{l}\text { 3. Energetic feeds } \\
\text { froducts containing a small level of protein (less than 20\%) and a small amount of crude } \\
\text { fiber (less than 18\%) }\end{array}$ \\
\hline $\begin{array}{c}\text { 5. Mineral } \\
\text { supplements }\end{array}$ & $\begin{array}{l}\text { Products from plant sources (cake and meal) and animal sources (blood meal, meat meal), } \\
\text { milk products containing a high level of protein (more than 20\%) }\end{array}$ \\
\hline $\begin{array}{c}\text { 6. Vitamin } \\
\text { supplements }\end{array}$ & Bone meal \\
\hline 7. Feed additives & Hormones, antibiotics, coloring materials, medicaments, etc. \\
\hline
\end{tabular}

Table 1.

Classes of feeds in Mali.

(8) fat, (9) treated feed, and (10) diverse products. Based on the sources, the appropriate classification for the Sahel countries is as shown in Table 1.

\subsection{Chemical composition and nutritive value of sheep common feeds}

From the classes of feeds (Table 1), the most common feeds used in most Sahelian countries are roughages (native grazing lands), agricultural byproducts (rice straw, corn, sorghum, millet stalks) and the agro-industrial byproducts like meals (cottonseed, peanut) and bran (rice, wheat, millet, and sorghum). Silages, known a long time ago, are not commonly used. Energetic feeds are used only in intensive sheep production such as in fattening sheep. Mineral supplements are used very often; vitamin supplements are less commonly used while feed additives are not used at all. Feeds are analyzed in the Animal Nutrition Lab $[19,20]$ of Institut d'Economie Rurale (IER). The most common analyses include dry matter, ash, crude protein, crude fiber, crude fat, gross energy, calcium, phosphorus, sodium, neutral detergent fiber (NDF), acid detergent fiber (ADF), and acid detergent lignin (ADL). Digestibility values are obtained with sheep (in vivo digestibility) or estimated from chemical composition using the following equations developed by INRA [14]:

$$
\begin{gathered}
\text { Grasses: } \mathrm{dOM}=93.2-0.104 \mathrm{CF}+0.025 \mathrm{CP} \\
\text { Legumes: } \mathrm{dOM}=78.9-0.059 \mathrm{CF} \\
\text { Cereals and coproducts: } \mathrm{dOM}=95.8-0.191 \mathrm{CF}-2.54 \\
\text { Peanut meal: } \mathrm{dOM}=87.75-0.0314 \mathrm{CF}-1.86 \\
\text { Cottonseed meal: } \mathrm{dOM}=87.75-0.0314 \mathrm{CF}+6.22
\end{gathered}
$$

where $\mathrm{d}$ = digestibility; $\mathrm{OM}=$ organic matter $\mathrm{CF}$ = crude fiber; and $\mathrm{CP}$ = crude protein.

The chemical composition of the common sheep feeds in the Sahel from Nantoumé et al. [13] —unpublished data is given in Annex 1.

\subsection{Nutritive value of common sheep feeds}

The energy value of feedstuffs and the energy requirements of animals have been expressed in gross energy (GE) using the formula GE $=4516+1.646$ 
$\mathrm{CP}+70 \pm 39$. Digestible energy and metabolizable energy were determined using the following equations:

$$
\begin{gathered}
\mathrm{DE}=\mathrm{GE} \times \mathrm{dE} / 100(\mathrm{dE}=1.055 \mathrm{dOM}-6.833) \text { with } \mathrm{dOM} \text { en\% } \\
\\
\mathrm{ME}=0.82 \mathrm{DE}
\end{gathered}
$$

where $\mathrm{DE}$ = digestible energy; $\mathrm{GE}$ = gross energy; $\mathrm{dE}$ = digestibility of energy; $\mathrm{dOM}=$ digestibility of organic matter; and $\mathrm{ME}$ = metabolizable energy.

For the net energy value, Institut National de la Recherche Agronomique (INRA) of France is recommending the use of forage unit for lactation (UFL) for maintenance, lactation, and animals of medium growth rate and forage unit for meat production (UFV) for fattening lambs and cattle having an average daily gain greater than $750 \mathrm{~g} / \mathrm{day}$. One feed unit corresponds to the net energy value of $1 \mathrm{~kg}$ barley for maintenance or production.

Under the actual Sahel conditions, the use of the two UF is difficult, and it is recommended to use UFL for all categories of sheep.

In the Sahel countries of Africa, the digestible proteins system is still much in use. The digestible protein system accounts for the apparent digestibility of the protein fraction. To determine digestible proteins, INRA [14] has recommended the following equations:

$$
\mathrm{DP}(\mathrm{g} / \mathrm{kg} \mathrm{DM})=9.1 \mathrm{CP}-0.38 \mathrm{OM}(\mathrm{OM} \text { and } \mathrm{CP} \text { in\%of DM) (for grass plants) }
$$

$\mathrm{DP}(\mathrm{g} / \mathrm{kg} \mathrm{DM})=8.7 \mathrm{CP}-0.41 \mathrm{OM}(\mathrm{OM}$ and $\mathrm{CP}$ in\%DM) (for legume plants)

where $\mathrm{DP}$ = digestible protein; $\mathrm{DM}=$ dry matter; $\mathrm{CP}$ = crude protein; and $\mathrm{OM}=$ organic matter.

Since 1979, INRA has been using widely the protein digested in the intestine (PDI) system which accounts for the digestibility of the protein fraction in the small intestine.

The nutritive value of the common sheep feeds in the Sahel from Nantoumé et al. [13] —unpublished data is given in Annex 1.

\section{Nutrient requirements of sheep}

The nutrient needs of sheep vary greatly according to the physiological stage: maintenance, growth, gestation, lactation, and fattening. The daily requirements can be found in several books. Table 2, from Memento de l'Agronome [21], gives the nutrient requirements of the ewe for maintenance, late gestation, and milk production, while Table 3 gives the nutrient requirements of ram for maintenance, growth, and fattening. The nutrient in consideration is energy expressed in forage unit for lactation, digestible protein (DP), digestible protein in the intestine, calcium $(\mathrm{Ca})$, and phosphorus (P).

Of primary importance in sheep nutrition are water, energy, protein, minerals, and vitamins.

\subsection{Water}

Water is essential for all livestock and must be planned for an adequate supply of clean water. Ordinarily, sheep consume two to three times as much water as dry 


\begin{tabular}{|c|c|c|c|c|c|c|c|}
\hline Liveweight (kg) & Performances & & UF & DP $(g)$ & PDI (g) & $\mathrm{Ca}(\mathrm{g})$ & $P(g)$ \\
\hline \multirow[t]{6}{*}{20} & Maintenance & & 0.31 & 24 & 25 & 2.0 & 1.5 \\
\hline & $\begin{array}{l}\text { 5th month of } \\
\text { gestation }\end{array}$ & & 0.38 & 36 & 38 & 2.8 & 1.9 \\
\hline & Lactation & Milk produced/day & & & & & \\
\hline & & $300 \mathrm{~g}$ & 0.51 & 53 & 50 & 3.5 & 2.2 \\
\hline & & $600 \mathrm{~g}$ & 0.72 & 82 & 74 & 5.0 & 2.8 \\
\hline & & $900 \mathrm{~g}$ & 0.92 & 111 & 99 & 6.5 & 3.5 \\
\hline \multirow[t]{6}{*}{30} & Maintenance & & 0.42 & 32 & 33 & 2.5 & 1.8 \\
\hline & $\begin{array}{l}\text { 5th month of } \\
\text { gestation }\end{array}$ & & 0.53 & 48 & 50 & 3.4 & 2.3 \\
\hline & Lactation & Milk produced/day & & & & & \\
\hline & & $400 \mathrm{~g}$ & 0.69 & 71 & 66 & 4.5 & 2.5 \\
\hline & & $800 \mathrm{~g}$ & 0.96 & 110 & 99 & 6.5 & 3.6 \\
\hline & & $1200 \mathrm{~g}$ & 1.24 & 148 & 131 & 8.5 & 4.4 \\
\hline \multirow[t]{6}{*}{40} & Maintenance & & 0.52 & 40 & 41 & 4.0 & 2.0 \\
\hline & $\begin{array}{l}\text { 5th month of } \\
\text { gestation }\end{array}$ & & 0.66 & 60 & 62 & 4.1 & 2.5 \\
\hline & Lactation & Milk produced/day & & & & & \\
\hline & & $500 \mathrm{~g}$ & 0.86 & 89 & 82 & 5.5 & 3.1 \\
\hline & & $1000 \mathrm{~g}$ & 1.20 & 137 & 123 & 8.0 & 4.2 \\
\hline & & $1500 \mathrm{~g}$ & 1.54 & 186 & 164 & 10.5 & 5.3 \\
\hline
\end{tabular}

Table 2.

Nutrient requirement of ewes for gestation and lactation with an average energy value of milk of $0.68 \mathrm{UFL} / \mathrm{kg}$ and a protein value of $60 \mathrm{~g} / \mathrm{kg}$.

matter. A generally applied estimate for water requirement is $2 \mathrm{ml}$ per gram of dry matter consumed [10]. The voluntary intake of water is affected by a number of factors such as ambient temperature, amount of activity, amount of dry matter eaten, level of salt intake, physiological state of animal, availability of water, stage of lactation, and composition of the ration (moisture content) and drinking interval. The needs increase at the end of gestation, during lactation, and during hot dry season. An ewe can drink up to 71 per day while in gestation and up to 15 during lactation [22]. Water supply, if limited, restricts voluntary feed intake and feed utilization of livestock depending on various factors and mechanisms [23, 24]. An excessive salt intake will increase the amount of water drunk. A safe limit of salts in drinking water is given as $1.5 \%$.

\subsection{Energy}

The energy needs of sheep vary greatly according to the physiological stage: maintenance, gestation, lactation, or growth. At a given physiological stage, the needs are the same but can be expressed in a different unit. The needs for maintenance correspond to the amount of feed necessary to maintain the weight of the animal. They are estimated in relation to the live weight of the animal. In complete confinement, the maintenance needs are usually stated as $95 \mathrm{kcal}$ metabolizable energy $/ \mathrm{kg}^{0.75}$ [22] and 1 to 1.2 forage unit for a $100 \mathrm{~kg}$ liveweight sheep [25]. 


\begin{tabular}{|c|c|c|c|c|c|c|}
\hline Liveweight (kg) & ADG (g) & UFL & DP $(g)$ & PDI (g) & $\mathrm{Ca}(\mathrm{g})$ & $P(g)$ \\
\hline \multirow[t]{6}{*}{20} & Maintenance & 0.31 & 24 & 25 & 2.0 & 1.5 \\
\hline & 50 & 0.51 & 40 & 40 & 3.1 & 2.0 \\
\hline & 80 & 0.57 & 50 & 50 & 3.8 & 2.3 \\
\hline & 110 & 0.62 & 59 & 58 & 4.4 & 2.6 \\
\hline & 140 & 0.68 & 69 & 68 & 5.1 & 2.9 \\
\hline & 170 & 0.75 & 79 & 77 & 5.8 & 3.2 \\
\hline \multirow[t]{4}{*}{30} & Maintenance & 0.42 & 32 & 33 & 2.5 & 1.8 \\
\hline & 70 & 0.72 & 56 & 55 & 4.1 & 2.5 \\
\hline & 110 & 0.80 & 65 & 63 & 5.0 & 2.9 \\
\hline & 150 & 0.90 & 77 & 74 & 5.8 & 3.3 \\
\hline \multirow[t]{4}{*}{40} & Maintenance & 0.52 & 40 & 41 & 3.0 & 2.0 \\
\hline & 75 & 0.95 & 63 & 62 & 4.7 & 2.9 \\
\hline & 110 & 1.06 & 71 & 69 & 5.5 & 3.1 \\
\hline & 145 & 1.18 & 82 & 79 & 6.2 & 3.5 \\
\hline
\end{tabular}

Table 3.

Nutrient requirement of ewes for growth and fattening.

The energy value of feedstuffs and the energy requirements of animals have been expressed in several units such as gross energy, digestible energy, metabolized energy, and net energy using forage unit. One forage unit corresponds to the net energy value of $1 \mathrm{~kg}$ barley for maintenance or production. Actually, two units from INRA [26] are used: forage unit for milk production and forage unit for meat production. The major sources of energy for sheep are hay, pasture, crop residues, agro-industrial byproducts, and even grains to raise the energy level of the diet when necessary. Energy deficiencies can cause reduced growth rate, loss of weight, reduced fertility, lowered milk production, and reduced wool quantity and quality.

The energy needs of sheep and the energy value of feedstuffs are expressed in several energy units such as forage unit, calorie, TDN, amidon unit, etc. In balancing rations it is required to use the same unit for both the energy needs of sheep and the energy value of feedstuffs.

\subsection{Protein}

In sheep rations, the amount of protein is much more important than the quality of protein. However, since sheep is a ruminant and mature, the naturally occurring protein and non-protein nitrogen (urea) are used effectively in their diets. Common sources of natural protein supplements include cottonseed and peanut meals that contain from 20 to $30 \%$ protein and are good sources of supplemental protein. High-quality legume hays can contain from 10 to $18 \%$ protein and provide adequate protein for most classes of sheep when fed as a complete ration.

Mature sheep can be fed low levels of non-protein nitrogen. In general, supplemental no-protein nitrogen is beneficial only when adequate energy is available. Urea should never make up more than one-third of the ruminally degradable protein in the diet. 
Sheep daily protein requirement is estimated to be $0.6 \mathrm{~g} / \mathrm{kg}$ body weight $[25,26]$. Similarly, the protein content of feedstuffs that can be expressed in several units can be found in the literature $[14,25]$.

\subsection{Minerals}

Some minerals are essential in sheep nutrition. Minerals essential for ruminants include macro minerals such as calcium, phosphorus, magnesium, sodium, potassium, chlorine, and sulfur and trace minerals such as copper, molybdenum, iron, manganese, zinc, selenium, cobalt, and iodine [27]. Most of these requirements are met under normal grazing and feeding habits in the Sahel countries. The necessity for the addition of minerals to the ration is determined by the character of the feed eaten, including the water consumed [10]. Maintaining optimum rumen fermentation with straw-based rations requires a minimum mineral supply as given by Moss et al. [28]. Those that are most deficient are salt (sodium chloride), phosphorus, and calcium.

Salt is essential for many body functions. When sheep are deprived of salt, they generally consume less feed and water, produce less milk, and grow slowly. Inadequate salt intake may cause decreased feed consumption and decreased efficiency of nutrient use [10]. In general, supplemental salt should be provided to range ewes at a level of 8 to $11 \mathrm{~g}$ of salt per head per day. For mixed feeds, an addition of $0.3 \%$ to the complete diet or $1 \%$ to the concentrate portion is recommended [27].

Pastures and hay are generally low in phosphorus; however, in grains the amount of phosphorous is moderate to high. Since any efficient sheep operation uses a high percentage of roughage or pasture, it is assumed that the sheep need phosphorus supplementation. Phosphorus deficiency causes slow growth, reduced appetite, abnormal bone development, and poor reproductive performance. It may be beneficial to provide phosphorus supplements year-round for the breeding flock.

\subsection{Vitamins}

Mature sheep require all the fat-soluble vitamins: A, D, E, and K. They do not require supplemental B vitamins, which can be synthesized in the rumen. Normally, the forage and feed supply contain all essential vitamins in adequate amounts, except vitamin A, which is sometimes deficient. Vitamin A does not occur in plant tissue but is synthetized by the animal from chemical precursors in plants, mainly beta carotene [29]. However, sheep can store vitamin A for a considerable time. If ewes have pastured on green forage or have had access to high-quality legume hay, vitamin A is not usually deficient.

\subsection{Strategies of feeding sheep}

The main resources used as sheep feed in the Sahel include pastures (herbaceous plants, fodder trees/shrubs), crop residues, cultivated forages, concentrate feed (agro-industrial byproducts, grains, feed supplements, etc.), and household wastes. The relative importance of these resources varies across production systems. Agroecology, seasonality, land tenure, and management practices at the farm level, among other factors, influence their availability [30]. In the agro-pastoral system, improvement of nutrition is based on the definition of a supplemental feeding strategy and on the improvement of the quality of low-quality forage [22]. 


\subsection{Range grazing}

Sheep are natural grazers, and they are easy to control through herding on natural range. In consequence, small children very often are herders. Sheep prefer short grass and have difficulty eating coarse feedstuffs [10]. Sheep frequently obtain critical protein and vitamins from browsing on leaves and fallen pods of different tree species. Grazing on natural ranges and marginal wasteland provides most of the annual feed intake of Sahel sheep. The fact that most grazing land is owned communally complicates improvement efforts.

\subsection{Crop residues}

The second most important feed resource for Sahel sheep is crop residues [31]. The usual practice is to permit free access to cropland after harvest is completed. This practice is used only partially, and part of the forage is used in other forms of feed. The kind and nature of residues depend on the crops grown. They include cereals (rice, sorghum, millet, corn, barley, wheat) and legumes (cowpea, groundnut).

\subsection{Forage preservation and storage}

Forage may be used as feed in five forms: pasture, hay, silage, cut and fed in the fresh or green state, and chemically treated. Silage and cut and fed in the fresh or green state are well known and applied in the Sahel countries. Although hay and silage making and forage treatment may have a considerable potential for bridging the dry season feed gap, their use needs further promotion in the Sahel.

Hay is the most important of all harvested roughages. The legume hays (e.g., cowpea and groundnut) are especially valuable, since they are high in protein, calcium, and other nutrients and are both palatable and highly digestible.

Silage results from the preservation of green forage under anaerobic conditions. The best grass silage can be made when the material contains 60 to $75 \%$ of moisture.

The concept of silage making is very old but rather less practiced. A pit of $3 \mathrm{~m}$ diameter and $2 \mathrm{~m}$ depth holds 6 to 8 tons of silage that is sufficient to feed 20 sheep for about 3 months.

The practice of leaving the straw and stover of harvested cereal crops in the fields to be grazed over by livestock may not be desired. The collection and stacking of these materials where they could be rationed out to livestock would increase the value of the feed several times. Other ways of increasing the feeding value of straws are through urea treatment [32] and proper supplementation with legume hays [33].

A third most important feed resource for Sahel sheep includes residues from the processing of the various agricultural products that are cottonseeds, cottonseed meal, groundnut meal, brans of cereals, molasses, etc.

\subsection{Seasonal consideration in Sahel feed supplies}

In the Sahel countries, mixed crop-livestock farming and pastoralism are the dominant forms of agricultural production. In these farming systems, sheep feeding depends mostly on rangeland, fallows, and cropland grazing. Nutritional constraints to grazing sheep are ecological zone variations, feed scarcity, and seasonal fluctuations in feed supply associated with low rainfall and poor soil fertility. The options to improve sheep nutrition vary seasonally in the Sahel countries. Due to seasonal fluctuations in the availability and quality of the feed resources, the intake 
of energy, protein, and some essential minerals by most ruminant species fall below their maintenance requirements resulting in undernutrition and low productivity in most production systems [34].

During the rainy season, the forage grows and the crops develop. At this stage the quality of the forage available is very high, and the main constraint is herd mobility. Grazing and moving herds to watering points may lead to conflicts between herders and farmers. Transhumance is a common practice in the West African Sahel based on regular seasonal migration from a permanent homestead to access to better range resources in terms of quality and plant species diversity and protection of crops from damage by grazing animals. The wet season grazing areas are also the location of sites for the "cure salé" to cover certain mineral deficiencies [3].

At the end of the rainy season, in the early dry season, all range forages including trees and crop residues are available in large amounts although their quality is relatively low because of lignification. Conserving crop residues and bush hay under cut-and-carry strategies may reduce spoilage and provide feed late in the dry season. Legume (groundnut and cowpea) hays are harvested and highly priced in local markets. They can be used to feed animals with higher protein requirement, such as lactating ewes and fattening sheep.

As the dry season progresses, aboveground forage mass decreases. Animals require longer grazing time and spend more energy walking. At this stage, it is advantageous to restrict walking by keeping animals on fields and feed them with the store feeds.

Late in the dry season, the lack of feed and low protein content limits the efficient use of the feed available. The main option during the late dry season and early rains consists in providing supplementary feeding with crop residues, bush hay, and/or grain byproducts and agro-industrial byproducts. Supplementary feeding with roughages will be determined by the availability of labor and cost of transport, whereas the use of concentrates will be a function of availability and cost of grain and agro-industrial byproducts.

Supplements are defined as special concentrate feeds that are fed to supply nutrients which are deficient in a ration to balance the ration for essential nutrients. Among the most relevant supplements most often needed in the Sahel are minerals, such as calcium and phosphorus and protein from byproducts feeds (oil cakes and cereal milling residues). Molasses can be used to increase energy and palatability and as carrier of non-protein nitrogenous substances such as urea.

\subsection{Practical guidelines for feeding}

Two types of feed resources available to the farmers can be considered: the onfarm feed resources such as range, fallow, and crop residues and the purchasable resources such as agro-industrial byproducts. The quality and quantity of grass are variable depending on the year, the season, and the ecological zone. However, in the Sahel, there are two main seasons within a year; for animal feeding purposes, the year can be divided into three seasons in the Sahel that are the rainy season from July to September, the dry cool season from October to February, and the dry hot season from March to mid-June. The season associated with the agroclimatic zone is the most important factor that drives feed supply in the Sahel.

\subsubsection{Coping with feed scarcity in the Sahel}

In the Sahel, aboveground forage is the major or sometimes the sole sheep feed resource. During the rainy season, feed supplies from grazing lands and fallow are 


\begin{tabular}{lccc}
\hline Categories & Rainy season & Dry and cold season & Dry and hot season \\
\hline Young & 0 & $100 \mathrm{~g}$ cottonseed meal & $100 \mathrm{~g}$ straw $+100 \mathrm{~g}$ cottonseed meal \\
\hline Adult & 0 & $200 \mathrm{~g}$ cottonseed meal & $200 \mathrm{~g}$ hay $+200 \mathrm{~g}$ cottonseed meal \\
\hline Ram & $\begin{array}{c}100 \mathrm{~g} \text { cottonseed } \\
\text { meal }\end{array}$ & $200 \mathrm{~g}$ cottonseed meal & $200 \mathrm{~g}$ hay $+200 \mathrm{~g}$ cottonseed meal \\
\hline Lactating & $\begin{array}{c}200 \mathrm{~g} \text { cottonseed } \\
\text { meal }\end{array}$ & $\begin{array}{c}400 \mathrm{~g} \text { cottonseed } \\
\text { meal }\end{array}$ & $200 \mathrm{~g}$ de grossier $+400 \mathrm{~g}$ cottonseed \\
meal
\end{tabular}

Table 4.

Quantities (g/animal/d) of supplements used for different categories depending on the season.

enough to cover maintenance requirements and even part of the production needs of the grazing sheep. However, the high producing sheep (lactating and fattening animals) may need supplemental feeds.

\subsubsection{Supplementation}

As the rainy season ends, aboveground forage mass decreases in quality because of lignification while the biomass is still available. At first, improving the feeding value of forages through proper preservation and storage may be enough to cover the deficit in nutrient requirements of the animal. High producing sheep may need concentrate supplement feeds.

When the dry season progresses from the cool season to the hot season, both quality and quantity of forages decrease. Therefore, both forages and concentrates may be used as feed supplements. An example of supplemental feeding of sheep in Mali is given in Table 4. A 2-year study conducted by Nantoumé et al. [35] using this supplemental feeding gave interesting results. Fertility, birth rate and numeric productivity were improved in ewes receiving supplemental feed. The times of kidding and of kids born per pregnancy were higher in supplemented animals. Feed supplements increased milk production per lactation from 26.1 to 43.21 for sheep [35].

\subsubsection{Intensive feeding}

The rational feeding of ewes is economically valid only if the farmer knows with precision the physiological stage of the ewes.

\subsection{Feeding ewes for gestation and milk production}

\subsection{Gestation}

The level of nutrition at the end of gestation has an important effect on the development of the lambs and thus their survival after birth, on the building of body reserves and on the maternal performances of the ewes, which will affect the post-natal growth of the lamb.

The growth of the fetus is especially important during the last third of gestation: 70 to $80 \%$ of the total weight gain occurs during this period. The last 6 to 8 weeks of gestation are thus critical in terms of nutrition because the nutrient requirements of the ewe increase tremendously. Supplementation of the ewe with a feed high in energy is extremely desirable. However, the supplementation is difficult to achieve because of the decrease of the ewe's appetite due to a reduction of the rumen capacity and the high cost of the high-energy feed. A low level of nutrition at the 


\begin{tabular}{lccc}
\hline Ration & ADG (g) & Benefit (F.CFA) & References \\
\hline $60 \%$ CSM + 40\% PH & 200 & 11,020 & Nantoumé et al. [36] \\
\hline $45 \%$ CSM + 47\% PH + 8\% Millet & 192 & 9415 & Nantoumé et al. [37] \\
\hline $35 \% \mathrm{BH}+35 \% \mathrm{NH}+30 \% \mathrm{ABH}$ & 172 & 6285 & Ballo et al. [38] \\
\hline $70 \% \mathrm{CSM}+30 \% \mathrm{DH}$ & 140 & 6065 & Nantoumé et al. [36] \\
\hline $61 \% \mathrm{CSM}+39 \% \mathrm{SS}$ & 124 & 5850 & Nantoumé et al. [39] \\
\hline $65 \% \mathrm{CSM}+25 \% \mathrm{NH}+10 \% \mathrm{CS}$ & 126 & 5310 & Nantoumé et al. [40] \\
\hline $52 \% \mathrm{CSM}+36 \% \mathrm{PH}+12 \% \mathrm{SS}$ & 142 & 5065 & Nantoumé et al. [40] \\
\hline $51 \% \mathrm{CSM}+28 \% \mathrm{SS}+21 \% \mathrm{Millet}$ & 132 & 5135 & Nantoumé et al. [40] \\
\hline $60 \% \mathrm{CSM}+20 \% \mathrm{~PB}+20 \% \mathrm{NH}$ & 146 & 4785 & Nantoumé et al. [37] \\
\hline $50 \%$ CSM $+39 \% \mathrm{BH}+11 \% \mathrm{Millet}$ & 142 & 4395 & Nantoumé et al. [40] \\
\hline $57 \%$ CSM + 30\% PH + 13\% MS & 135 & 4220 & Nantoumé et al. [37] \\
\hline CSM = cottonseed meal; PH = peanut haulm; BH = bush hay; DH = dolichos haulm; SS = sorghum straw; NH = niébé \\
haulm; CS = corn straw; and MS = millet straw.
\end{tabular}

Table 5 .

Characteristics of the best fattening rations of a series of sheep fattening experiments.

end of gestation will have negative effects not only on the reproduction performance of the ewe but also on its health.

Normal growth of the fetus allows the lambs to be born with adequate weight. The weight at birth directly influences the vigor of the lamb and its resistance to stress.

\subsection{Milk production}

The mammary tissue grows rapidly at the end of gestation; $95 \%$ of the development occurs during the last 6 weeks of gestation. Without adequate nutrition, the udder develops less; as a consequence, it will lower milk production. Good nutrition of the ewe at the end of gestation increases milk production by 20 to $30 \%$ in the ewe carrying a single lamb. Besides, the nutrient requirements of the ewe for gestation and milk increase depending on the level of milk production (Table 3). Moreover, a good level of nutrition at the end of gestation favors the constitution of reserves that the ewe will utilize during the high-energy requirements of lactation.

Milk production generally increases during the first 3 weeks, reaches a plateau, and starts decreasing rapidly. The form of the curve varies according the breed, the level of nutrition, and the number of lambs suckling. The voluntary intake of most forages in early lactation is generally insufficient to meet the nutrient requirements. A supplementation of 400 to $600 \mathrm{~g}$ per day of a high-quality concentrate is needed.

\subsection{Sheep fattening}

In most countries of the Sahel, sheep fattening is a common operation especially during the Muslim's feast. It consists in feeding rams for a rapid weight gain during a short period of time. Fattening rations should be formulated from local supplies at the least cost as far as possible. Several fattening rations were developed throughout the Sahel countries. In the Malian context, 11 fattening rations were developed. Average daily gain (ADG) varied from 124 to $200 \mathrm{~g}$ with benefit fluctuating from 4395 to 11,020 FCFA (Table 5). After the successful on-station trial, the two best rations have been tested on-farm condition. 


\section{Conclusion}

The overall results of our study showed that sheep farming is an important economic activity of most of the population. This review shows that seasonal fluctuations of feed resources in the Sahel follow the pattern of vegetation growth that is modified by the availability of rainfall. This resulted in a seasonal pattern of wet season gain and dry season loss of liveweight. Seasonal fluctuation in availability and poor quality of feeds were considered to be the main constraints on sheep farming in the Sahel. Appropriate supplemental feeding improved productivity of ewes. The times of kidding and of kids born per pregnancy were higher in supplemented animals. Feed supplements increased milk production per lactation from 26.11 to 43.21 for sheep [35]. For intensive meat production, several rations economically sound were also developed. For health care, the recommendations are known. For infectious diseases such as pasterollesis and peste des petits ruminants, it is mandatory to vaccinate them regularly twice a year for the first and once a year for the second disease. Deworming is also recommended twice, three times, or four times a year depending on the zones (Sahel, soudanian and preguinean) where the sheep are.

\section{Annex 1}




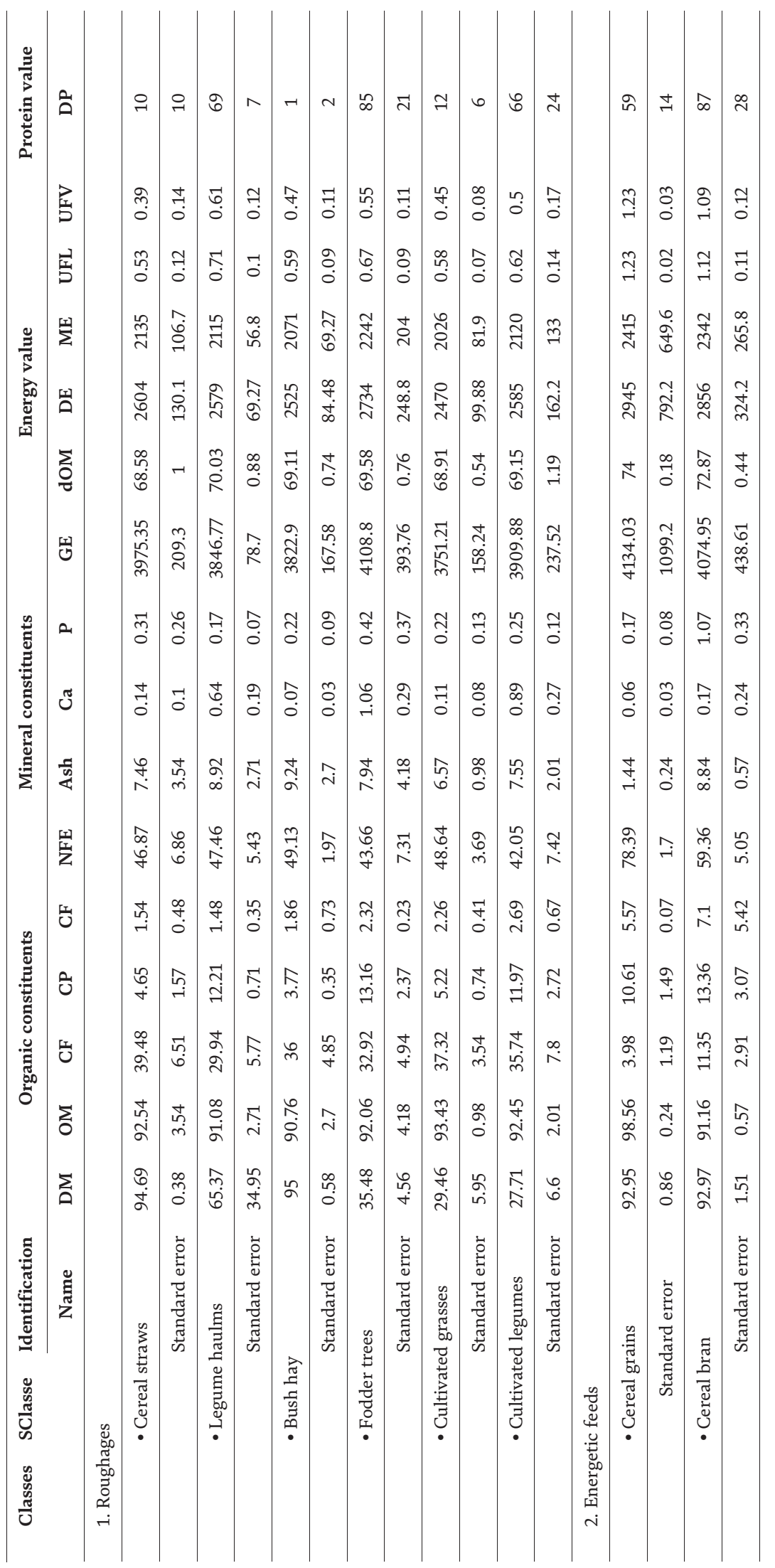




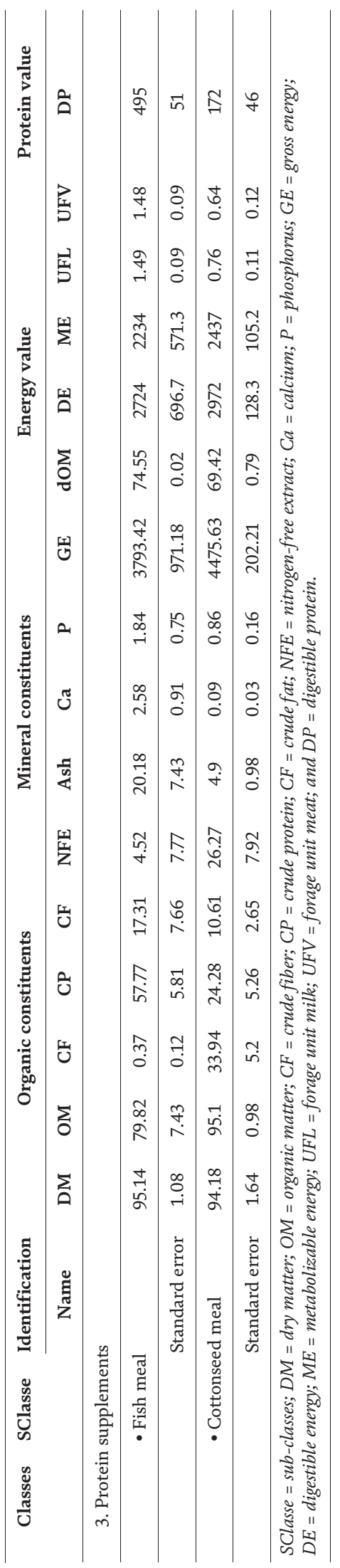




\section{Author details}

Hamidou Nantoumé

Institut d'Économie Rurale (IER), Bamako, Mali

*Address all correspondence to: hamidou.nantoume@yahoo.fr

\section{IntechOpen}

(C) 2020 The Author(s). Licensee IntechOpen. This chapter is distributed under the terms of the Creative Commons Attribution License (http://creativecommons.org/licenses/ by/3.0), which permits unrestricted use, distribution, and reproduction in any medium, provided the original work is properly cited. (cc) BY 


\section{References}

[1] Qureshi AW. Animal production: An African perspective? Summaries. In: 6th All Africa Conference on Animal Agriculture. Nairobi, Kenya: Kenyatta International Convention Center (KICC); 1996. pp. 1-13

\section{[2] Kreuzer M. Coping with}

Undernutrition in ruminants: Strategies to minimize adverse metabolic and environmental effect. In: Jarurasitha S, editor. Trends in Livestock Production in Thailand. Proceedings of the symposium held in Chiang Mia University, Thailand; 1997. pp. 210-228

[3] de Leeuw PN, Hiernaux P. Pluviosité. In: Wilson RT, de Leeuw PN, de Haan C, editors. Recherches sur les systèmes de production des zones arides du Mali (Résultats préliminaires). Addis Ababa, Ethiopia: CIPEA. 1983. pp. 19-23

[4] Sangaré M. Opportunities of available feed resource utilization for animal feeding and nutrient cycling in the Sahel [PhD thesis in Tropical Animal Production]. Antwerp, Belgium: Department of Tropical Animal Production and Health, Institute of Tropical Medicine Prince Léopold; 2002. 202 p

[5] Sivakumar MVK, Konaté M, Virmani SM. Agroclimatologiy of West Africa: Mali. Information Bulletin No. 19. Andhara Pradesh, India: International Crops Research Institute for the SemiArid Tropics-ICRISAT; 1984

[6] Mulumba JBK, Somda J, Sanon Y, Kagoné $H$. Élevage et marché régional au Sahel et en Afrique de l'Ouest. Potentialités et défis. CSAO-OCDE/ CEDEAO. 2008. 182 p. Available from: https://www.oecd.org/fr/csao/publica tions/40279092.pdf

[7] Dicko MS, Djitèye MA, Sangaré M. Les systèmes de production animale au Sahel. Sécheresse. 2006;17:83-97
[8] Toulmin C. Livestock Losses and Post-Drought Rehabilitation in SubSaharan Africa. LPU Working Paper No. 9. Addis Ababa, Ethiopia: International Livestock Centre for Africa; 1985

[9] Pradère J. Performances and Constraints of Livestock in Mali. Project for African Agricultural development: Improvement of Agricultural Policies in the West and Central African Countries. France, Dakar: FIDA, France OCDE, Hub Rural; 2007. 73 p

[10] Devendra C, McLeroy GB. Goat and sheep production in the Tropics. In: Payne WJA, editor. International Tropical Agriculture series. London, New York: Longman; 1982. 271 p

[11] Sangaré M. Synthèse des résultats acquis sur l'élevage des petits ruminants dans les systèmes de production animale d'Afrique de l'Ouest PROCORDEL, CIRDES URPAN, CIRDES 01 BP 454 Bobo-Dioulasso 01. Burkina: Faso; 2005. $176 \mathrm{p}$

[12] Swift JJ, Wilson RT, Hamsworth J. Les systèmes de production animale en Afrique de l'Ouest. In: Wilson RT, de Leeuw PN, de Haan C, editors. Recherches sur les systèmes de production des zones arides du Mali (Résultats Préliminaires). Addis Ababa, Ethiopia: CIPEA; 1983. pp. 19-23

[13] Nantoumé H, Cissé S, Sow PS, Sidibé S, Kouriba A, Olivier A, et al. Impact des rations comportant des fourrages de Pterocarpus lucens et Ficus gnaphalocarpa sur l'embouche ovine au Mali. Tropicultura. 2018;36:1-11

[14] INRA. Alimentation des bovins, ovins et caprins. Besoins des animaux. Valeurs des aliments. Tables INRA 2007. Edition Quae. Versailles: Cedex; 2007. $307 \mathrm{p}$

[15] Harris LE, Haendler H, Rivière R, Réchaussat L. International Feed 
Databank System: An Introduction into the System with Instructions for Describing Feeds and Recording Data. International Network of Feed Information Centers. Logan, Utah, USA: Prepared on Behalf of INFIC by the International Feedstuffs Institute, Utah Agricultural Experiment Station, Utah State University; 1980. 127 p

[16] Harris LE. Symposium on feeds and meat terminology: III. A system for naming and describing feeds, energy terminology and the use of such information in calculating diets. Journal of Animal Science. 1963;22:535

[17] Harris LE, Kearl LC, Fonnesbeck PV. A Rationale for Naming Feeds. Bulletin 501. Logan, Utah, USA: International Feedstuffs Institute, Utah Agricultural Experiment Station, Utah State University; 1981. 309 p

[18] Baumont R, Dulphy JP, Sauvant D, Tran G, Meschy F, Aufrère J, et al. Les tables de la valeur des aliments. In: Alimentation des bovins, ovns et caprins. Besoins des animaux. Valeurs des aliments. Table INRA 2007 Editions Quae c/o Inra. RD. 10 78026. Versailles: Cedex; 2007. 307 p

[19] Nantoumé H, Kouriba A, Togola D. Evaluation de la valeur alimentaire des chaumes de céréales et des fanes de légumineuses. World Review of Animal Production. 1995;30:107-112

[20] Nantoumé H, Kouriba A, Togola D, Ouologuem B. Mesure de la valeur alimentaire de fourrages et de sousproduits utilisés dans l'alimentation des petits ruminants. Revue d'Elevage et de Médecine Véterinaire des Pays tropicaux. 2000;53:279-284

[21] Memento de l'Agronome. Ministère des Affaires Etrangères. Centre de la Coopération Internationale et de recherche agronomique pour le développement (CIRAD). Groupe de recherche et d'échange technologique
(GRET). Jane. 11 bd de Sébastopol 75001. Paris. 2002. 1691 p

[22] Small Ruminant CRSP. Sheep

Production and Management in a Mediterranean Climate. The Agro Pastoral System of Marocco. Office of Agriculture. Bureau for Research and Development. United States Agency for International Development, under grant No DAN-1328-G-00-0046-00. 1993

[23] ARC. The Nutrient Requirement of Ruminant Livestock. Wallingford, Oxon, UK: CAB (Commonwealth Agricultural Bureaux) International; 1980. $118 \mathrm{p}$

[24] Langhans W, Rossi R, Scharrer E. Relationship between feed and water intake in ruminants. In: van Engelhandt W, Leonhard W, Leonhard-Mareck S, Breves G, Giesecke D, editors.

Ruminant Physiology Digestion Metabolism, Growth, and Reproduction. Proceedings of the VIII International Symposium on Ruminant Physiology Held at Wellington, Germany, 10-14 September 1994; Stuttgart, Germany: Ferdinand Enke Verlag, D-70443; 1995. pp. 199-216

[25] Rivière R. Manuel d'alimentation des ruminants domestiques en milieu tropical. Institut d'Elevage et de Médecine vétérinaire des pays tropicaux. 2nd ed. Paris: Imprimerie JOUVE; 1978. $527 \mathrm{p}$

[26] INRA. Alimentation des bovins, ovins et caprins. Besoins des animaux, Valeurs des aliments. Tables Inra 2007. Edition Quae. 2017. 307 p

[27] McDowell LR, Conrad JH, Ellis GL. Mineral deficiencies and imbalances and their diagnois. In: Gilchrist FMC, Mackie RI, editors. Herbivore Nutrition in the Subtropics and Tropics. Craighall South Africa: The Science Press; 1984. pp. 67-88

[28] Moss AR, Given DI, Garnsworthy PC. The effect of alkali treatment of 
cereal straws on digestibility and methane production by sheep. Animal Feed Science and Technology. 1994;49: 245-259

[29] Huston JE, Pinchak WE. Range animal nutrition. In: Heitschmidt RK, Stuth JW, editors. Grazing Management: An Ecology Perspective. Portland, Oregon: Timber Press; 1993. pp. 27-63

[30] Williams TO, Fernandez-Rivera S, Kelly TG. The influence of socioeconomic factors on the availability and utilization of crop residues as animal feeds. In: Renard C, editor. Crop Residues in Sustainable Mixed Crop/ Livestock Farming Systems.

Wallingford, UK: CAB (Commonwealth Agricultural Bureaux) International; 1997. pp. 25-39

[31] Kebreab ET, Tanner SJ, Osuji P. Review of undernutrition in smallholder ruminant production systems in the tropics. In: Ayantunde AA, FernandezRivera S, McCrabb G, editors. Coping with Feed Scarcity in Smallholder Livestock Systems in Developing Countries. Wageningen, the Netherlands/Zurich, Switzerland/ Nairobi, Kenya: Animal Sciences Group, Wageningen University \& Research/ University of Reading, UK, ETH (Swiss Federal Institute of Technology)/ILRI; 2005. 306 p

[32] Nantoumé $H$, Kouriba $A$, Ouologuem B. Effets de la durée de conservation et du séchage sur la teneur en azote des fourrages pauvres traités à l'urée. Revue d'Elevage et de Médecine Véterinaire des Pays Tropicaux. 2001; 54:43-46

[33] Nantoumé H, Kouriba A, Togola D, Coulibaly BS. Effets de la supplémentation de la paille de brousse avec différentes proportions de fane de dolique sur la production de viande ovine. In: Small Ruminant Research and Development in Africa: Proceedings de l'atelier tenu du; 5-9 December 1994; Kampala, Uganda; 1994. pp. 205-207

[34] Larbi A, Olaloku EA. Influence of plane of nutrition on productivity of ruminants in the sub-humid zone of West Africa. In: Ayantunde AA, Fernandez-Rivera S, McCrabb G, editors. Coping with Feed Scarcity in Smallholder Livestock Systems in Developing Countries. Nairobi, Kenya/ Wageningen, the Netherlands/Zurich, Switzerland: ILRI/Animal Sciences Group, Wageningen University \& Research/University of Reading, UK, ETH (Swiss Federal Institute of Technology); 2005. 306 p

[35] Nantoumé H, Kouriba A, Diarra CHT, Coulibaly D. Amélioration de la productivité des petits ruminants: Moyen de diversification des revenus et de lutte contre l'insécurité alimentaire. Livestock Research for Rural Development. 2011;23:5. Available from: http://www.lrrd.org/lrrd23/5/na nt23110.htm

[36] Nantoumé H, Diarra CHT, Traoré D, Kouriba A, Maïga H. Performances de l'engraissement des moutons Maures avec des rations à base de tourteau de coton dans la région de Kayes au Mali. Les cahiers de l'économie rurale. 2005;1: 28-36

[37] Nantoumé H, Diarra CHT, Traoré D. Performance et rentabilité économique de l'incorporation des quatre fourrages de qualité pauvre dans des rations d'engraissement des moutons Maures. Livestock Research for Rural

Development. 2006;18(01):2006

[38] Ballo A, Nantoumé H, Kouriba A, Kodio A, Touré SA. Performances économique et bouchère de l'embouche ovine avec des rations à base du foin de bourgou (Echinochloa stagnina) ou de la paille de sorgho (Sorghum vulgare). Les cahiers de l'économie rurale. 2003;0:19-27

[39] Nantoumé H, Diarra CHT, Traoré D. Performance et rentabilité 
économique de la valorisation des fourrages pauvres par le tourteau de coton dans l'engraissement des moutons Maures au Mali. Livestock Research for Rural Development. 2009;21:12.

Available from: http://www.lrrd.org/ lrrd23/5/nant23110.htm

[40] Nantoumé H, Ballo A, Kouriba A. Techniques d'embouche ovine. Bamako, Rue Mohamed V: IER; 2007. 21 p 
Section 2

Sheep Growth and Health 



\title{
Body Weight Gain and Carcass Yield Characteristics of Wollo Highland Sheep and Their $\mathrm{F}_{1}$ Crossbreeds
}

\author{
Tadesse Amare Sisay, Gebeyehu Goshu Negia and \\ Berhan Tamir Mersso
}

\begin{abstract}
In the study area, sheep flocks are managed under traditional extensive systems with no or minimal inputs and improved technologies, which results in low productivity. The available natural pasture lands are overloaded with livestock beyond optimum carrying capacity that has resulted in overgrazing and land degradation. This indicates the critical need of supplemental feed during feed-deficient period. The objective of the research was assessment of productive performance through on-station feedlot and natural pasture grazing effect on weight gain and carcass yield characteristics evaluation. The average daily weight gain (ADG), total body weight change and final body weights of supplemented groups significantly higher than ( $\mathrm{p}<0.05)$ non-supplemented groups. Hence, supplemented and nonsupplemented Awassi crossbreds had higher daily weight gain and followed by supplemented Wollo highland group. Between genotypes, there is significant difference $(p<0.05)$ of rib-eye area, empty body weight, hot and cold carcass weight and cold carcass dressing percentage. Conversely, Wollo highland sheep has exhibited compensatory growth rate than others. Awassi crossbred lambs has higher weight gain and faster growth performance followed by Washera crossbred one. Therefore, local breed productive performance improvement practices have to continue and need adjustment of breeding strategies with a definite breeding plan.
\end{abstract}

Keywords: body weight, carcass, Awassi and Washera, $\mathrm{F}_{1}$ crossbred and Wollo highland

\section{Introduction}

Ethiopia is not only rich in sheep population but also rich in sheep genetic diversity, which developed by natural selection and potential genetic resources of sheep breeds [1]. In the highlands of the country, about $75 \%$ of sheep population are found, while the remaining $25 \%$ are distributed in the lowlands [2]. Sheep production is a major component of the livestock sector in Ethiopia, owing to the large population of 30.70 million sheep are estimated to be found in the country, out of which about $72.14 \%$ are females, and about $27.86 \%$ are males [3]. The small 
ruminants account for $40 \%$ of cash income earned by farm households, $19 \%$ of the total value of subsistence food derived from all livestock production, and $25 \%$ of total domestic meat consumption [4]. Smallholder sheep production is the major source of food security serving a diverse function, including cash income, savings, fertilizer, socio-cultural functions and fiber production. Sheep are particularly important for farmers in the subalpine highlands and pastoralist/agropastoralist where crop production is unreliable. Moreover, despites its socio-cultural importance, sheep resources significantly contributed for foreign currency earning accounting for the live animal exports [1].

The cool highland sheep production systems in most highland areas are characterized by erratic and unevenly distributed rainfall, recurrent drought, and scarcity in livestock feeds and feed that is poor in quality [5]. In those production environments, the role of sheep in supporting the livelihood of smallholder farmers is increasing due to recurrent crop failure $[5,6]$. However, the sheep flocks are managed under traditional extensive systems with no or minimal inputs and improved technologies, which results in low productivity. They depend on natural pasture and fibrous crop residues for their survival, growth and reproduction. The available natural pasture lands are overloaded with livestock beyond optimum carrying capacity that has resulted in overgrazing and land degradation $[7,8]$. This indicated the critical need of supplemental feed during the feed-deficient period and wise management of communal and private natural pasture grazing. A limited supply of nutrients in the sheep's diet can lead to weight loss, low fertility, high mortality, increased risk of disease and poor wool growth. Sheep need a balanced diet containing energy (fat and carbohydrates), protein, vitamins, minerals, and water. Sheep and goat production in Ethiopia suffers feed shortages at all levels with an estimated $40 \%$ deficit in the national feed balance. This is aggravated by seasonal availability of forage and crop residues in the highlands and by recurrent and prolonged drought in the lowlands.

Therefore, the study was accomplished on, assessment of productive performance through on-station feedlot based and natural pasture grazing weight gain performance and carcass yield characteristics evaluation of indigenous Wollo highland sheep breed and their $\mathrm{F}_{1}$ crossbreds with $75 \%$ Awassi and pure indigenous Washera breed rams.

The specific objectives of the study are:

- to evaluate on-station feedlot weight gain and carcass yield characteristics of Wollo highland sheep and their $\mathrm{F}_{1}$ crossbreds of Awassi and Washera sheep breeds.

- to assess natural grass grazing value as basal diet for the study breeds supplemented by concentrated feed.

\section{Material and methods}

\subsection{Description of the study area}

This research was conducted from 2018 to 2019 in the two selected areas of Dessie Zuria and Kutaber districts in South Wollo Zone of Amhara Region, Ethiopia. The geographical location of South Wollo Zone is delimited with North Shewa and Oromia region in the Southern part, East Gojjam in the West, South Gondar in the Northwest, North Wollo in the North, Afar Region in the Northeast and Argobba district of the Oromia Zone in the Eastern part (Figure 1). 
Body Weight Gain and Carcass Yield Characteristics of Wollo Highland Sheep and Their... DOI: http://dx.doi.org/10.5772/intechopen.92340

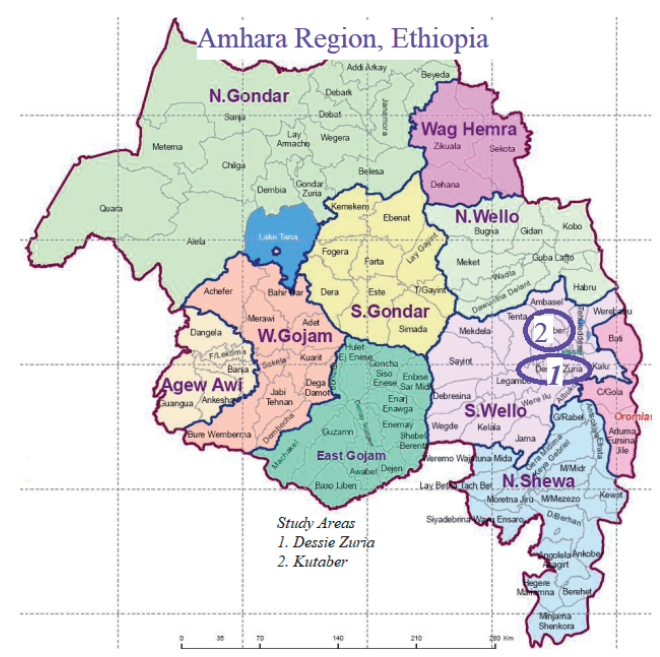

Figure 1.

Description of the study area.

\subsection{Experimental design and treatments}

A $3 \times 2$ factorial experimental design arrangement of three genotype and two feeding type factors with six treatment levels (three genotypes by two feeding type's combinations) and six replications were used. The three genotypes belonging to $50 \%$ Awassi $\mathrm{F}_{1}$ crosses, $50 \%$ Washera $\mathrm{F}_{1}$ crosses and $100 \%$ local Wollo highland lambs were grouped in to three by their genotypes and in to two by their feeding types of supplemented and non-supplemented groups for each genotypes. The supplemented and non-supplemented feeding types randomly assigned for each 36 experimental animals.

Both supplemented and non-supplemented groups grazed for 8 hours/day as a basal diet with rotational grazing system and animal holding of 36 sheep/0.5 ha paddock/day. The supplemented group fed at the rate of $1 \%$ of their body

\begin{tabular}{lll}
\hline Local name & Scientific name & Growth form \\
\hline Akirma & Cynodon nlemfuensis & Grass-perennial \\
\hline Tult & Asarum canadense & Herb-annual \\
\hline Sindedo & Urochloa brizantha & Grass-perennial \\
\hline Serdo & Cynodon dactylon & Grass-annual \\
\hline Gicha & Cyperus rotundus & Grass-annual \\
\hline Gazia & Dactylis glomerata L. & Grass-perennial \\
\hline Arintata & Trifolium repens & Herb-annual \\
\hline Others & - & - \\
\hline Muja & Snowdenia polystachya & Grass-annual \\
\hline Gudign & Dichondra repens & Herb-annual \\
\hline Ketema & Cyperus polystachyos & Grass-perennial \\
\hline Bare land & - & - \\
\hline
\end{tabular}

Table 1.

Species composition of private owned natural pasture grass land. 
weight/day of concentrate mix diet, whereas the non-supplemented group fed only natural pasture grazing area for 8 hours/day from 8:00 AM to 5:30 PM with a 1 hour rest from 12:30 AM to 1:30 PM and had free access of drinking water.

\subsection{Experimental animals grazing management}

The grazing land characterized by both annual and perennial grass such as Cyperus rotundus, Dactylis glomerata Cynodon nlemfuensis, Cynodon dactylon, Cyperus polystachyos and Urochloa brizantha (Table 1). The size of natural pasture grazing area was 2.5 ha of land and that sub-divided into five paddocks with each individual paddock size was 0.5 ha.

\subsection{Body weight gain and linear body measurements}

Lambs were weighed at 15 days of interval for 1 year in the last week of each month using a $0.1 \mathrm{~kg}$ precision scale. Lambs were weighed at birth and fortnightly thereafter up to weaning. After weaning at the age of about 90 days they were weighed in 15 days interval together with the rest of the flock. Lamb body weights were adjusted by age.

The average daily weight gain (ADG) was calculated using the following formula at on-farm growth performance study:

$$
A D G=\frac{d W 2 K g+W 1 K g}{A} * 1000
$$

where ADG g = average daily gain in gram, $\mathrm{W} 1 \mathrm{~kg}=$ birth weight or weight at the preceding age, $\mathrm{W} 2 \mathrm{~kg}$ = weight at a given age, and $\mathrm{A}=$ age in days or days between weighing dates.

Average daily gain was calculated for the following stages of growth: (a) pre-weaning weight average daily gain (PreADG) ADG = birth to 90 days of age, (b) post-weaning weight average daily gain (PoADG) = birth to 365 days of age, and (c) weaning weight $=$ at average body weight at 90 days.

Average daily weight gain of ram lambs in the on-station growth performance evaluation was also calculated using the following formula:

$$
A D G=\frac{F W T K g+I W T K g}{A D} * 100
$$

where FWT = final body weight, IWT = initial body weight, and D = number of fattening days.

Linear body measurements were taken together with 3 months of interval measurements (from 3 months of age to 12 months). All body measurements were taken with a measuring tape in centimeter and measured to the nearest $0.5 \mathrm{~cm}$. Linear body measurements traits were taken: (a) heart girth is the circumference of the chest posterior to the forelegs at right angles to the body axis, (b) wither height is the highest point measured as the vertical distance from the top of the shoulder to the ground, (c) body length is the distance between the crown and the sacrococcygeal joint, (d) tail width is directly behind the tuber ichiad, and (e) tail circumference is directly behind the tuber ichiad.

Model 1. On-station growth of initial and final body weight, average daily gain (ADG) of ram lambs (9 months-365 days of age):

$$
\text { Yijlklm }=\mu+\mathrm{Bi}+\mathrm{F}_{l}+\left(\mathrm{B}_{i} \times \mathrm{F}_{l}\right) \mathrm{ijm}+\text { eijklm }
$$


Body Weight Gain and Carcass Yield Characteristics of Wollo Highland Sheep and Their...

DOI: http://dx.doi.org/10.5772/intechopen.92340

where Yijklm = average daily gain (ADG) and body weight change, $\mu=$ overall mean, $\mathrm{Bi}=$ fixed effect of the $i$ th breed $\left(\mathrm{i}=\right.$ Awassi $\mathrm{F}_{1}$ crossbred, Washera $\mathrm{F}_{1}$ crossbred and local Wollo highland breed), $\mathrm{F}_{l}$ = fixed effect of the feeding type ( 1 = supplemented, 2 = non-supplemented), $\left(\mathrm{B}_{i} \times \mathrm{F}_{l}\right)_{i l}=$ breed by feeding type interaction effect and eil $=$ effect of the $n$th random error.

Model 2. Weight and linear body measurements of male lambs (90-365 days of age):

$$
Y i j=\mu+B i+B t j+e i j
$$

where Yij = body weight and linear body measurements at 90, 180, 270 and 365 days of age, $\mu=$ overall mean, $\mathrm{Bi}=$ fixed effect of the ith breed $\left(\mathrm{i}=\right.$ Awassi $\mathrm{F}_{1}$ crossbred, Washera $F_{1}$ crossbred and local Wollo highland breed), Btj = fixed effect of the jth birth type ( $j$ = single, twins), eij = effect of the oth random error.

Model 3. Body weight gain, carcass and non-carcass parameters:

$$
Y i j k=\mu+B i+F j+W k+e i j k
$$

where Yijk = body weight gain, carcass and non-carcass parameter, $\mu=$ mean, $\mathrm{Bi}=$ effect of the ith breed ( $\mathrm{i}=$ Awassi $\mathrm{F}_{1}$ crossbred, Washera $\mathrm{F}_{1}$ crossbred and local Wollo highland breed), $\mathrm{Fj}$ = the fixed effect of feeding type ( $\mathrm{j}$ = supplemented, nonsupplemented), Wk = the random effect of body weight ( $k$ = birth weight, preweaning weight $\mathrm{ADG}$, weaning weight, post-weaning weight ADG and yearling weight, empty body weight, pre-slaughter weight), eijk = effect of the kth random error.

\subsection{Data analysis}

According to a $3 \times 2$ factorial statistical designs of the breed and diet as main effects and the PROC GLM of multivariate analysis package of the SAS Windows 9.0-2004 system used for those data fitted with the main factors of breed, feeding type, sex, birth type and parity effects on body weight gain response variable in the model. Initial body weight was also used as a covariate factor in the model to control the residual effects of initial body weight on consecutive rate of body weight gain. The dependent variables include body weight, average daily weight gain, survival rates, linear body measurements, reproductive traits and carcass yield characteristic parameters were considered in the GLM multivariate analysis of variance. The stepwise procedure of Pearson correlation of the SAS system was used to see the effects of association between body weight and linear body measurement traits. Tukey's standardized range significance test was used to compare the different groups of mean.

\section{Results}

\subsection{Effects of genotype and supplementation feed on ram lambs growth rate}

Genotype and supplementation diet effect on ram lambs' average body weight and their daily weight gain is presented in Table 2 . Initial body weight had significant $(p<0.05)$ difference between genotypes and used in the covariate analysis model to avoid its residual effect on consecutive body weight gain and to quantify the genotype effect. However, it has non-significant difference within genotypes. The between and within genotype variations were continued throughout 10, 20 and 


\begin{tabular}{|c|c|c|c|c|c|c|c|}
\hline \multirow[b]{2}{*}{$\begin{array}{l}\text { ABW } \\
(\mathrm{kg})\end{array}$} & \multicolumn{2}{|c|}{ Awassi genotype } & \multicolumn{2}{|c|}{ Wollo genotype } & \multicolumn{2}{|c|}{ Washera genotype } & \multirow[b]{2}{*}{ Sig.L } \\
\hline & T1 & $\mathrm{T} 2$ & $\mathrm{~T} 1$ & $\mathrm{~T} 2$ & $\mathrm{~T} 1$ & $\mathrm{~T} 2$ & \\
\hline IBW & $31.6 \pm 1.0^{\mathrm{a}}$ & $31.5 \pm 0.8^{\mathrm{a}}$ & $21.9 \pm 0.7^{\mathrm{b}}$ & $21.4 \pm 0.5^{\mathrm{b}}$ & $26.4 \pm 0.7^{c}$ & $26.6 \pm 0.7^{c}$ & $* * *$ \\
\hline 10 days & $33.4 \pm 0.9^{a}$ & $34.0 \pm 0.9^{a}$ & $26.9 \pm 0.9^{b}$ & $24.5 \pm 0.9^{b}$ & $29.0 \pm 0.5^{c}$ & $27.5 \pm 0.5^{\mathrm{d}}$ & * \\
\hline 20 days & $33.3 \pm 1.1^{a}$ & $34.1 \pm 1.1^{\mathrm{a}}$ & $26.6 \pm 1.1^{\mathrm{c}}$ & $24.2 \pm 1.1^{\mathrm{b}}$ & $28.8 \pm 0.6^{c}$ & $26.9 \pm 0.6^{c}$ & * \\
\hline 30 days & $36.7 \pm 1.3^{\mathrm{a}}$ & $36.9 \pm 1.3^{\mathrm{a}}$ & $28.4 \pm 1.3^{\mathrm{b}, \mathrm{c}}$ & $26.3 \pm 1.3^{\mathrm{b}}$ & $30.3 \pm 0.7^{c}$ & $29.0 \pm 0.7^{c}$ & * \\
\hline 40 days & $37.8 \pm 1.3^{\mathrm{a}}$ & $37.7 \pm 1.3^{\mathrm{a}}$ & $29.3 \pm 1.3^{\mathrm{b}}$ & $27.0 \pm 1.3^{\mathrm{d}}$ & $30.6 \pm 0.7^{c}$ & $29.2 \pm 0.7^{c}$ & * \\
\hline 50 days & $38.3 \pm 1.7^{a}$ & $36.1 \pm 1.7^{\mathrm{b}}$ & $30.8 \pm 1.7^{\mathrm{c}, \mathrm{e}}$ & $28.4 \pm 1.7^{\mathrm{d}}$ & $31.1 \pm 0.9^{\mathrm{e}}$ & $29.4 \pm 0.9^{c, d}$ & * \\
\hline 60 days & $38.8 \pm 1.8^{\mathrm{a}}$ & $35.8 \pm 1.8^{\mathrm{b}}$ & $32.4 \pm 1.7^{c}$ & $29.8 \pm 1.8^{\mathrm{d}}$ & $32.1 \pm 1.0^{c}$ & $29.9 \pm 1.0^{\mathrm{d}}$ & $* *$ \\
\hline 70 days & $39.9 \pm 1.8^{a}$ & $37.3 \pm 1.8^{\mathrm{b}}$ & $33.3 \pm 1.8^{\mathrm{d}}$ & $30.4 \pm 1.8^{c}$ & $32.2 \pm 1.0^{\mathrm{c}, \mathrm{d}}$ & $30.6 \pm 1.0^{\mathrm{e}, \mathrm{c}}$ & $* *$ \\
\hline 80 days & $41.4 \pm 1.8^{\mathrm{a}}$ & $38.2 \pm 1.8^{\mathrm{b}}$ & $34.4 \pm 1.8^{c}$ & $31.1 \pm 1.8^{\mathrm{d}}$ & $33.1 \pm 1.0^{c}$ & $31.3 \pm 1.0^{\mathrm{d}}$ & $* *$ \\
\hline FBW & $45.5 \pm 1.4^{\mathrm{a}}$ & $42.4 \pm 1.4^{\mathrm{b}}$ & $35.2 \pm 1.3^{c}$ & $31.6 \pm 1.4^{\mathrm{d}}$ & $34.4 \pm 0.7^{c}$ & $32.4 \pm 0.7^{\mathrm{d}}$ & $* * *$ \\
\hline BWC & $16.1 \pm 1.1^{\mathrm{a}}$ & $13.4 \pm 1.1^{\mathrm{b}}$ & $8.9 \pm 1.1^{c}$ & $7.5 \pm 1.1^{\mathrm{d}}$ & $6.0 \pm 0.6^{\mathrm{e}}$ & $5.9 \pm 0.6^{\mathrm{e}}$ & $* *$ \\
\hline ADG (g) & $178.5 \pm 12.3^{\mathrm{a}}$ & $148.3 \pm 12.4^{\mathrm{b}}$ & $98.4 \pm 12.2^{\mathrm{c}}$ & $83.5 \pm 12.3^{\mathrm{d}}$ & $66.6 \pm 6.7^{\mathrm{e}}$ & $65.2 \pm 6.7^{\mathrm{e}}$ & $* *$ \\
\hline \multicolumn{8}{|c|}{$\begin{array}{l}{ }^{*} P<0.05,{ }^{* *} P<0.01,{ }^{* * *} P<0.001 \text {. } \\
\text { ABW, average body weight gain; } F B W \text {, final body weight gain; } B W C \text {, body weight change; } A D G \text {, average daily } \\
\text { weight gain; T1, supplemented; T2, not-supplemented; superscript with the same letter is not significant and different } \\
\text { letters has significant difference (across the row); SE, standard error of the mean. }\end{array}$} \\
\hline
\end{tabular}

Table 2.

Genotype and supplemented diet effect on ram lambs body weight gain.

30 days experimental period except supplemented Washera $F_{1}$ crossbreds and Wollo highland breed lambs and which were significantly higher than their nonsupplemented group at 10 and 20 days treatment period, respectively. Despite the fact that at 30, 40, 50 and 60 days of feed treatment period the supplemented group of Wollo highland breed lambs had non-significant differences with both supplemented and non-supplemented Washera crossbred lambs and between breed variation eliminated. At 40 and 50 days, treatment period, except Wollo highland lambs the other genotypes have insignificant differences between supplemented and non-supplemented groups. Conversely, at 60 days of treatment period supplemented Wollo highland breed lambs had non-significant variation with both supplemented and non-supplemented Washera $F_{1}$ crossbred lambs and vice versa. Awassi $\mathrm{F}_{1}$ crossbred lambs significantly $(\mathrm{p}<0.05)$ higher average weight gain than both Wollo highland and Washera $\mathrm{F}_{1}$ cross ram lambs throughout the experimental period (Table 2).

The total body weight changes from initial to final body weight higher in supplemented Awassi crossbred lambs and followed by their non-supplemented group. Supplemented and non-supplemented Wollo highland lambs observed better growth performance than Washera $\mathrm{F}_{1}$ crossbreds. Therefore, on-station feed supplementation effect had fastest growth performance record with Awassi $\mathrm{F}_{1}$ crossbred lambs than Wollo highland and Washera $\mathrm{F}_{1}$ crossbred lambs. Supplemented Wollo highland lambs had faster growth rates than their nonsupplemented group. Supplemented Washera crossbred lambs had a comparable body weight change to non-supplemented group.

Even though, Wollo highland breed had faster body weight change and average daily gain than Washera $F_{1}$ crossbred lambs, the supplemented group of Washera 
Body Weight Gain and Carcass Yield Characteristics of Wollo Highland Sheep and Their...

DOI: http://dx.doi.org/10.5772/intechopen.92340

crossbred lambs had higher final body weight gain than supplemented Wollo highland breed lambs. The final body weight of non-supplemented Washera crossbred lambs had higher than non-supplemented Wollo highland lambs.

\subsection{Genotypes and supplementation effect on carcass characteristic performance}

Carcass and non-carcass yield characteristics included, pre-slaughtered weight, slaughter body weight, empty body weight, fasting loss, hot carcass weight, cold carcass weight, total edible proportion, non-carcass organs, rib-eye area, fat and lean meat thickness and commercial yield were presented in Table 2.

Slaughtered and empty body weight bases of the supplemented and nonsupplemented groups did not significant difference for each genotype. However, significant variations recorded between the three genotypes. Subsequent to 24 hours of fasting period (except water) the body weight losses and hot carcass weight had comparable value within breeds. However, Awassi crossbred lambs lost more than Washera crossbred and Wollo highland breed lambs. Even though Awassi $\mathrm{F}_{1}$ crossbred lambs lost higher body weight than others during fasting period, it is significantly $(\mathrm{P}<0.05)$ higher hot carcass weight than Washera $\mathrm{F}_{1}$ crossbreds and Wollo highland ram lambs. Nevertheless, fasting loss and hot carcass weight have comparable value between supplemented and non-supplemented Wollo highland and Washera crossbred lambs.

Fat thickness of both supplemented and non-supplemented groups of Awassi crossbred lambs had significantly higher than Wollo highland and nonsupplemented Washera crossbred lambs. Despite the fact that, supplemented Washera crossbred lambs, had comparable fat thickness with supplemented Awassi crossbred lambs. Awassi crosses had significantly higher a total non-carcass weight than both Washera and Wollo highland breed lambs, but did not show within breed difference. Between supplemented and non-supplemented Washera genotype and supplemented local Wollo highland breed did not have significant variation of total non-carcass components and non-supplemented Wollo highland lambs significantly lower than others.

\subsection{Carcass yield traits correlation coefficient analysis}

Slaughtered body weight had strong positive and significant correlation with empty body weight, hot and cold carcass weight, rib-eye area $\left(\mathrm{cm}^{2}\right)$, fat thickness $\left(\mathrm{mm}^{2}\right)$ and slight positive correlation with lean thickness $\left(\mathrm{mm}^{2}\right)$. However, it had inverse correlation with commercial yield \% (cold carcass weight/slaughtered body weight $\times 100$ ) carcass trait. Empty body weight has strong and positive correlation with cold and hot carcass weight, and rib-eye area $\left(\mathrm{cm}^{2}\right)$. However, poor and positively associated with lean meat thickness $\left(\mathrm{mm}^{2}\right)$.

Hot carcass weight had perfect positive significant correlation with rib-eye area $\left(\mathrm{cm}^{2}\right)$ of lean meat composition, medium positive correlation with fat thickness and poorly correlated with amount of commercial yield (Table 3 ). The cold carcass weight trait has positive and intermediate correlation with rib-eye area and with lean meat thickness and poorly positive correlation with commercial yield feature. Likewise, rib-eye area carcass trait contents had medium positive association with fat thickness and lean meat thickness attribute. However, it had poor and positive correlation with commercial yield percentage composition, while fat thickness amount of the carcass had positive and medium correlation with lean meat thickness in the entire carcass, but negatively correlated with commercial yield percentage 


\begin{tabular}{|c|c|c|c|c|c|c|c|}
\hline \multirow{2}{*}{$\begin{array}{l}\text { Carcass } \\
\text { traits }\end{array}$} & \multicolumn{2}{|c|}{ Awassi $F_{1}$ crossbreds } & \multicolumn{2}{|c|}{ Wollo highland breed } & \multicolumn{3}{|c|}{ Washera $F_{1}$ crossbreds } \\
\hline & T1 & $\mathrm{T} 2$ & T1 & $\mathrm{T} 2$ & T1 & $\mathrm{T} 2$ & Sig. L \\
\hline SBW (kg) & $47.4 \pm 0.8^{\mathrm{a}}$ & $44.6 \pm 0.6^{\mathrm{b}}$ & $32.5 \pm 1.4^{\mathrm{c}}$ & $29.3 \pm 1.1^{\mathrm{d}}$ & $32.6 \pm 0.5^{c}$ & $32.2 \pm 0.5^{c}$ & *** \\
\hline EBW $(\mathrm{kg})$ & $35.3 \pm 1.3^{\mathrm{a}}$ & $32.4 \pm 1.3^{\mathrm{a}}$ & $24.5 \pm 1.7^{\mathrm{b}}$ & $20.5 \pm 1.7^{\mathrm{b}}$ & $26.9 \pm 0.9^{c}$ & $26.8 \pm 0.9^{c}$ & ** \\
\hline HCW (kg) & $20.8 \pm 1.6^{\mathrm{a}}$ & $20.2 \pm 1.6^{\mathrm{a}}$ & $14.7 \pm 1.2^{\mathrm{b}}$ & $13.5 \pm 1.2^{\mathrm{b}}$ & $16.0 \pm 0.5^{\mathrm{c}}$ & $13.2 \pm 0.5^{\mathrm{b}}$ & $* * *$ \\
\hline CCW (kg) & $18.3 \pm 1.4^{\mathrm{a}}$ & $18.2 \pm 1.4^{\mathrm{a}}$ & $11.7 \pm 1.0^{\mathrm{b}}$ & $11.6 \pm 1.0^{\mathrm{b}}$ & $14.9 \pm 0.4^{\mathrm{c}}$ & $12.5 \pm 0.4^{\mathrm{c}, \mathrm{b}}$ & ** \\
\hline HCWDP (\%) & $43.9 \pm 3.2^{\mathrm{a}}$ & $45.3 \pm 3.2^{\mathrm{b}}$ & $45.2 \pm 3.2^{\mathrm{b}}$ & $46.1 \pm 3.2^{\mathrm{b}}$ & $49.1 \pm 0.3^{c}$ & $41.0 \pm 0.3^{\mathrm{d}}$ & * \\
\hline CCWDP (\%) & $38.6 \pm 2.9^{a}$ & $40.8 \pm 2.9^{b}$ & $36 \pm 5.2^{c}$ & $39.6 \pm 5.2^{\mathrm{a}, \mathrm{b}}$ & $45.7 \pm 1.8^{\mathrm{d}}$ & $38.8 \pm 1.8^{\mathrm{a}}$ & * \\
\hline TEP (kg) & $25.1 \pm 1.8^{\mathrm{a}}$ & $23.8 \pm 1.8^{\mathrm{a}}$ & $17.4 \pm 1.6^{\mathrm{b}}$ & $17.2 \pm 1.6^{\mathrm{b}}$ & $19.6 \pm 0.7^{\mathrm{c}}$ & $17.6 \pm 0.7^{\mathrm{b}}$ & ** \\
\hline $\operatorname{REA}\left(\mathrm{cm}^{2}\right)$ & $15.9 \pm 0.2^{\mathrm{a}}$ & $15.5 \pm 0.2^{\mathrm{a}}$ & $7.3 \pm 0.1^{\mathrm{b}}$ & $6.5 \pm 0.1^{\mathrm{b}}$ & $9.2 \pm 0.1^{\mathrm{c}}$ & $7.3 \pm 0.1^{\mathrm{b}}$ & ** \\
\hline TNCW (kg) & $14.5 \pm 1.3^{\mathrm{a}}$ & $12.2 \pm 1.3^{\mathrm{a}, \mathrm{b}}$ & $10.8 \pm 1.3^{\mathrm{b}}$ & $6.9 \pm 1.3^{c}$ & $10 \pm 1.3^{\mathrm{b}}$ & $12.9 \pm 1.3^{\mathrm{b}}$ & * \\
\hline FT (mm) & $0.3 \pm 0.1^{\mathrm{a}}$ & $0.3 \pm 0.1^{\mathrm{a}}$ & $0.2 \pm 0.0^{\mathrm{b}}$ & $0.2 \pm 0.0^{\mathrm{b}}$ & $0.3 \pm 0.2^{\mathrm{a}}$ & $0.2 \pm 0.2^{\mathrm{b}}$ & * \\
\hline \multicolumn{8}{|c|}{$\begin{array}{l}\text { T1, supplemented; T2, non-supplemented; SBW, sloughter body weight; EBW, empty body weight; HCW, hot carcass } \\
\text { weight; CCW, cold carcass weight; HCWDP, hot carcass weight dressing percentage; CCWDP, cold carcass weight } \\
\text { dressing percentage; TEP, total edible propertion; REA, rib-eye area; TNCW, total non-carcass weight. Superscript } \\
\text { with the same letter is not significant and different letters has significant difference. }\end{array}$} \\
\hline
\end{tabular}

Table 3.

Analysis of variability for genotype and diet effects on carcass traits.

composition. In other ways lean meat content of the carcass had poor positive correlation with commercial yield of the whole carcass composition (Table 3 ).

\subsection{Genotype and supplementation effects on carcass morphometric traits}

Carcass morphometric characteristics of the present study were described by carcass length, lean meat weight, lean meat length, compactness index, chest width, shoulder width, and lean meat thickness presented in Table 4. Hence, the length of the carcass and lean meat had significantly higher for Awassi and followed by Washera crossbred lambs. Between the supplemented and non-supplemented groups of each genotypes, comparable carcass and lean meat length were recorded, however, significantly different between genotypes. Lean meat thickness significantly higher for both supplemented and non-supplemented Awassi $\mathrm{F}_{1}$ crossbred

\begin{tabular}{|c|c|c|c|c|c|c|}
\hline Body weight (kg) & SBW & EBW & HCW & CCW & REA & LMT \\
\hline EBW & $0.87^{* *}$ & & & & & \\
\hline $\mathrm{HCW}$ & $0.82^{* *}$ & $0.77^{* *}$ & & & & \\
\hline CCW & $0.86^{* *}$ & $0.79^{* *}$ & $0.98^{* * *}$ & & & \\
\hline $\operatorname{REA}\left(\mathrm{cm}^{2}\right)$ & $0.82^{* *}$ & $0.77^{* *}$ & $0.99^{* * *}$ & $0.98^{* * *}$ & & \\
\hline LMT $\left(\mathrm{mm}^{2}\right)$ & $0.52^{*}$ & $0.50^{*}$ & $0.54^{*}$ & $0.554^{*}$ & $0.54^{*}$ & \\
\hline CY (\%) & -0.15 & -0.01 & 0.42 & 0.36 & 0.42 & 0.08 \\
\hline \multicolumn{7}{|c|}{$\begin{array}{l}\text { SBW, slaughter body weight; EBW, empty body weight; HCW, hot carcass weight; CCW, cold carcass weight; REA } \\
\text { rib-eye area; } L M T \text {, lean meat thickness; CY, commercial yield. } \\
{ }^{* * *} \text { Correlation is significant at the } 0.001 \text { level (two-tailed). } \\
{ }^{* *} \text { Correlation is significant at the } 0.01 \text { level (two-tailed). } \\
\text { Correlation is significant at the } 0.05 \text { level (two-tailed). }\end{array}$} \\
\hline
\end{tabular}

Table 4.

Pearson correlation coefficient of carcass yield characterestics. 
Body Weight Gain and Carcass Yield Characteristics of Wollo Highland Sheep and Their...

DOI: http://dx.doi.org/10.5772/intechopen.92340

lambs. Between supplemented and non-supplemented groups of Wollo highland breed and Washera, crossbred lambs had significant difference.

The carcass composition of lean meat weight amount is significantly higher with Awassi crossbred lambs than Washera crossbred and Wollo highland breed lambs. Supplemented Wollo highland lambs and Washera crossbred lambs had proportional amount of lean meat weight. The carcass compactness index is measured by grams of lean meat per centimeters of its length. Carcass compactness index, chest and shoulder width had comparable records for all genotypes except chest width for Awassi genotype.

\subsection{Genotype and supplementation feed effects on non-carcass fat distribution}

The effects of genotype and supplementation diet effect on non-carcass fat distribution presented in Table 5. Thus, the non-carcass fat contents around the scrotal fat organ had not significant variation between supplemented and non supplemented group of each genotypes. However, between Wollo highland breed and Awassi crossbred lambs had a significant variation of scrotal fat contents. Likewise, Washera and Awassi crossbred lambs had significant differences between supplemented and non supplemented groups of scrotal fat contents. While, kidney fat composition of Awassi crossbred lambs and Wollo highland breed lambs had significantly lower than that of Washera crossbred lambs (Table 5).

Whereas, significant difference recorded between three genotypes of total non carcass fat contents. Both supplemented and non supplemented group of Awassi F1 crossbred lambs had higher composition of total non-carcass fat contents followed by Washera crossbred lambs. In general all supplemented groups were comprised of higher numerical value of non carcass fat composition, but not significantly different with non supplemented groups.

\subsection{Genotype and feed effects on non-carcass edible and non-edible components}

According to intellectual prohibited cultural and religious taboo of the local communities the edible components of non-carcass organs were presented as liver, tongue, heart, kidney, empty gastrointestinal part and tail fat were the most

\begin{tabular}{|c|c|c|c|c|c|c|}
\hline \multirow{2}{*}{$\begin{array}{l}\text { Carcass } \\
\text { morphometric traits }\end{array}$} & \multicolumn{2}{|c|}{ Awassi $F_{1}$ crossbreds } & \multicolumn{2}{|c|}{ Wollo highland breed } & \multicolumn{2}{|c|}{ Washera $F_{1}$ crossbreds } \\
\hline & T1 & $\mathrm{T} 2$ & T1 & $\mathrm{T} 2$ & $\mathrm{~T} 1$ & $\mathrm{~T} 2$ \\
\hline Carcass length $(\mathrm{cm})$ & $74.3 \pm 1.2^{\mathrm{a}}$ & $73.7 \pm 1.2^{\mathrm{a}}$ & $63.0 \pm 1.9^{\mathrm{b}}$ & $64.0 \pm 1.9^{\mathrm{b}}$ & $70.3 \pm 2.2^{c}$ & $68.0 \pm 2.2^{c}$ \\
\hline $\begin{array}{l}\text { Lean meat thickness } \\
(\mathrm{mm})\end{array}$ & $12.5 \pm 2.4^{\mathrm{a}}$ & $11.0 \pm 2.4^{\mathrm{a}}$ & $9.0 \pm 0.7^{b}$ & $6.4 \pm 0.7^{c}$ & $12.0 \pm 0.5^{\mathrm{a}}$ & $6.3 \pm 0.5^{c}$ \\
\hline Lean meat weight $(\mathrm{kg})$ & $0.7 \pm 0.03^{\mathrm{a}}$ & $0.7 \pm 0.03^{\mathrm{a}}$ & $0.5 \pm 0.1^{b}$ & $0.5 \pm 0.1^{\mathrm{b}}$ & $0.6 \pm 0.1^{b}$ & $0.5 \pm 0.1^{b}$ \\
\hline Lean meat length $(\mathrm{cm})$ & $55.3 \pm 1.2^{\mathrm{a}}$ & $54.7 \pm 1.2^{\mathrm{a}}$ & $44.0 \pm 1.9^{\mathrm{b}}$ & $45.0 \pm 1.9^{b}$ & $51.3 \pm 2.2^{c}$ & 49. $\pm 2.2^{c}$ \\
\hline $\begin{array}{l}\text { Compactness index } \\
(\mathrm{g} / \mathrm{cm})\end{array}$ & $12.1 \pm 0.8$ & $12.0 \pm 0.8$ & $11.8 \pm 0.8$ & $11.9 \pm 0.8$ & $12.4 \pm 0.9$ & $10.5 \pm 0.9$ \\
\hline Chest width $(\mathrm{cm})$ & $13.9 \pm 0.6^{\mathrm{a}}$ & $13.7 \pm 0.6^{\mathrm{a}}$ & $9.2 \pm 1.0^{\mathrm{b}}$ & $8.1 \pm 1.0^{b}$ & $10.9 \pm 0.9^{b}$ & $8.8 \pm 0.9^{b}$ \\
\hline Shoulder width $(\mathrm{cm})$ & $17.7 \pm 0.6$ & $18.1 \pm 0.6$ & $14.4 \pm 0.6$ & $14.2 \pm 0.6$ & $17.1 \pm 0.6$ & $15.0 \pm 0.6$ \\
\hline
\end{tabular}

Table 5 .

Between and within genotype carcass morphometric traits variability. 


\begin{tabular}{lcccccc}
\hline $\begin{array}{l}\text { Non- } \\
\text { carcass fat } \\
\text { traits (g) }\end{array}$ & \multicolumn{2}{c}{ Wollo highland breed } & \multicolumn{2}{c}{ Awassi F $_{1}$ crossbreds } & \multicolumn{2}{c}{ Washera $\mathbf{F}_{1}$ crossbreds } \\
\cline { 2 - 7 } & $\mathrm{T} 1$ & $\mathrm{~T} 2$ & $\mathrm{~T} 1$ & $\mathrm{~T} 2$ & $\mathrm{~T} 1$ & T2 \\
\hline Scrotal fat & $8.7 \pm 2.9^{\mathrm{c}}$ & $10.7 \pm 2.1^{\mathrm{c}}$ & $33 \pm 6.7^{\mathrm{b}}$ & $40 \pm 6.7^{\mathrm{b}}$ & $13.7 \pm 4.4^{\mathrm{c}}$ & $15.7 \pm 4.4^{\mathrm{c}}$ \\
\hline Pelvic fat & $29.3 \pm 3.5^{\mathrm{a}}$ & $26.7 \pm 3.5^{\mathrm{a}}$ & $30.7 \pm 3.1^{\mathrm{a}}$ & $27.7 \pm 3.1^{\mathrm{a}}$ & $47.0 \pm 10.6^{\mathrm{c}}$ & $38.3 \pm 10.6^{\mathrm{c}}$ \\
\hline Kidney fat & $25.3 \pm 2.0^{\mathrm{a}}$ & $23.3 \pm 2.0^{\mathrm{a}}$ & $60 \pm 18^{\mathrm{a}}$ & $63 \pm 18.0^{\mathrm{a}}$ & $171.0 \pm 52.4^{\mathrm{c}}$ & $89.3 \pm 52.4^{\mathrm{c}}$ \\
\hline $\begin{array}{l}\text { Mesentery } \\
\text { fat }\end{array}$ & $55.3 \pm 8.5^{\mathrm{a}}$ & $43.3 \pm 8.5^{\mathrm{a}}$ & $414 \pm 38.7^{\mathrm{b}}$ & $317.7 \pm 38.7^{\mathrm{b}}$ & $233.3 \pm 64.1^{\mathrm{c}}$ & $145.0 \pm 64.1^{\mathrm{c}}$ \\
\hline & & & & & \\
\hline
\end{tabular}

Table 6.

Non-carcass fat distribution traits variability between and within genotypes.

common. Hence, liver and heart weight had comparable value for Wollo highland and Washera crossbred lambs; however, Awassi crossbred had significantly higher amount of liver and heart weight. At the same time, non-significant record was observed between supplemented and non-supplemented groups of all genotypes. While the kidney and empty gastrointestinal weight had comparable value for all genotypes and feeding type factors, there was no significant difference both within and between genotypes and feeding types. Whereas the tail weight had comparable value between the three genotypes, Washera crossbred had a numerically higher quantity of tail weight than others (Table 6).

Except kidney weight of non-supplemented Awassi and Washera $F_{1}$ crossbreds and supplemented Wollo highland breed lambs, the edible non-carcass components not significant variation between supplemented and non-supplemented groups. However, except kidney weight and GIT empty weight, genotype had significant variation on non-carcass edible components. Except tail fat weight composition, in all edible noncarcass components of the Awassi crossbred lambs had the largest portion (Table 6).

Wollo highland breed had a comparable tail fat composition with Awassi crossbred lambs. However, both genotype and supplementation diet did not had significant differences with kidney and empty gastrointestinal weight of supplemented and non-supplemented groups. Subsequently, the non-edible, non-carcass components were skin, head, testicle and genital organ, blood, bladder, pancreas, feet, digestive contents and spleen which prohibited by the local communities cultural and religious taboo.

\section{Discussion}

\subsection{Genotype and supplemented diet effects on body weight gain and carcass traits}

The availability and supply of animal feed in the tropics is not constant in terms of both quantity and quality particularly in arid and semiarid regions seasonal fluctuation in the growth rate of animal in these regions $[9,10]$. This is particularly true in the study area, where the main source of animal feed is grazing on natural pasture. For this reason, to use whatever available resource more economically, it will be advantageous to identify those breeds of animals which are more efficient meat producers [11] or animals which have high performance in feed conversion efficiency to produce saleable products [11]. 
Body Weight Gain and Carcass Yield Characteristics of Wollo Highland Sheep and Their...

DOI: http://dx.doi.org/10.5772/intechopen.92340

\subsection{Effects of genotype and supplementation on body weight gain performance}

Genotypes and supplementation feed effects on ram lambs' body weight gain presented in Table 2. Initially the body weight gain of the three genotypes significantly different $(\mathrm{p}<0.05)$ each other and the differences were come from breed effects but not significant differences within group in each treatment. To avoid the effects of initial body weight on the successive body weight gain, covariate analysis was used and the adjusted initial body weight at $26.56 \mathrm{~kg}$ of all genotypes. In the present study, significantly higher average daily weight gain observed on the supplemented group implied that they were adequately fed and their maintenance and growth nutrient requirements were satisfied compared with non-supplemented groups (grazing only).

The average daily weight gain (ADG), the rate of body weight change and final body weights of supplemented group of Awassi, and Washera $\mathrm{F}_{1}$ crossbred and Wollo highland breed ram lambs were significantly higher $(\mathrm{p}<0.05)$ than nonsupplemented groups. As a result, Awassi $\mathrm{F}_{1}$ crossbred lambs' growth rate had significantly greater $(p<0.05)$ than both Wollo highland and Washera $F_{1}$ crossbred ram lambs throughout the experimental period and followed by supplementing Wollo highland breed ram lambs. The reason behind this might be the genetic potential difference of the three genotypes affecting average daily weight gain efficiency with different extent. Therefore, genotype is the limiting factor affecting average daily weight gain of lambs and in agreement with reported by Hammell and Laforest [12] for Polled Dorset, Hampshire and Romanov breeds.

The total amount of body weight change and the rate of daily weight gain indicated Wollo highland breed lambs were significantly greater than both supplemented and non-supplemented groups of Washera $\mathrm{F}_{1}$ crossbred lambs. This indicated improved grazing management condition and supplementation diet of Wollo highland breed lambs can have comparable body weight gain potential with their Washera $F_{1}$ crossbreds with the same management condition [13-15].

In general the Awassi $\mathrm{F}_{1}$ crossbred ram lambs have a promising growth performance with supplementation of local available concentrate feed. Hence, with controlled management condition of natural pasture grazing has contributed to better growth performance of ram lambs body weight gain. Furthermore, Washera F1 crossbreed lambs have an imperative body weight change and can be another alternative to enhance genetic potential of pure local Wollo highland breed, and in addition to this, inbreeding coefficient risk can be reduced. Moreover, costeffective concentrate feed supplementation on natural pasture grazing need appropriate attention by fatteners, and other sheep producers. Together with this private controlled grazing management, system had also played a great role to improve the body weight gain of ram lambs through quality pasture production.

\subsection{Effects of genotype and supplemented feed on carcass yield characteristics}

Carcass composition used as tool to characterize breeds for possible identification of potential genetic resource for lean lamb production and also to identify management alternatives to suit different breeds [16]. Therefore, breed is known to influence not only carcass composition and quality but also carcass conformation as well, differences in carcass merits between breeds is likely to govern the choice and development of breeds for specific production objectives.

Slaughter and empty body weight between supplemented and nonsupplemented groups variation not significant for all genotypes. The reason behind this might be less significant variation between supplemented and nonsupplemented body weight before slaughter and relatively comparable amount of 
fasting loss. Nevertheless, significant variations between the three genotypes recorded, and which in agreement with Orr [17] and Lakew et al. [18]. Subsequent to 24 hours of fasting period, the body weight losses had a comparable amount for all genotypes and not significant variation observed. The loss of rumen contents through defecation and urination effects of fasting period not significantly different among genotypes (Table 7).

Hot carcass weight has comparable value between supplemented and non-supplemented groups. However, between genotypes a significant variation $(\mathrm{p}<0.001)$ reported and which in agreement with Orr [17] and Lakew et al. [18]. Therefore, Awassi $\mathrm{F}_{1}$ crossbred ram lambs significantly higher $(\mathrm{p}<0.001)$ hot carcass weight than Wollo highland and Washera $\mathrm{F}_{1}$ crosses (Table 2). This is because of higher slaughtered body weight and higher average daily weight gain (ADG) effect and their comparable fasting loss. Assefu $[19,20]$ reported there was no breed effect in hot carcass weight between Horro and Washera breeds and which disagree with present study.

Cold carcass weight used as commercial carcass yield indicator trait used for productive performance tools to evaluate the productivity of a given meat animals. Awassi crossbred lambs' cold carcass weight significantly $(\mathrm{p}<0.05)$ greater than both Washera crosses and Wollo highland breed lambs. Within each genotype, cold carcass weight did not have significant difference because of the higher amount of chilling loss rate of supplemented groups (Table 7). This indicated that, the supplemented feed does not bring significant impact on cold carcass weight and agreement with Awgichew [10] for Menz and Horro breed lambs and Jorge et al.

\begin{tabular}{|c|c|c|c|c|c|c|c|c|}
\hline \multirow[t]{2}{*}{ Non-carcass components } & \multicolumn{2}{|c|}{$\begin{array}{c}\text { Awassi crosses } \\
\text { (means) }\end{array}$} & \multicolumn{2}{|c|}{$\begin{array}{l}\text { Wollo highland } \\
\text { breed (means) }\end{array}$} & \multicolumn{2}{|c|}{$\begin{array}{c}\text { Washera } \\
\text { crosses (means) }\end{array}$} & \multirow[b]{2}{*}{ SE } & \multirow[b]{2}{*}{ P-value } \\
\hline & T1 & $\mathrm{T} 2$ & T1 & $\mathrm{T} 2$ & T1 & $\mathrm{T} 2$ & & \\
\hline \multicolumn{9}{|l|}{ I. Edible non-carcass traits } \\
\hline Liver (g) & $717.0^{\mathrm{a}}$ & $541.3^{\mathrm{a}}$ & $332.0^{\mathrm{b}}$ & $384.3^{\mathrm{b}}$ & $445.0^{\mathrm{c}}$ & $453.0^{c}$ & 76.0 & $* *$ \\
\hline Tongue (g) & $137.8^{\mathrm{a}}$ & $143.2^{\mathrm{a}}$ & $109.3^{\mathrm{b}}$ & $114.3^{\mathrm{b}}$ & $91.9^{c}$ & $89.8^{\mathrm{c}}$ & 7.0 & $* * *$ \\
\hline Heart $(\mathrm{g})$ & $190.3^{\mathrm{a}}$ & $127.3^{\mathrm{a}}$ & $61.3^{\mathrm{c}}$ & $68.3^{\mathrm{c}}$ & $68.3^{\mathrm{c}}$ & $75.3^{\mathrm{c}}$ & 25.5 & $* *$ \\
\hline Kidney (g) & $63.3^{\mathrm{a}}$ & $66.0^{\mathrm{b}}$ & $64.3^{\mathrm{a}, \mathrm{b}}$ & $59.0^{\mathrm{c}}$ & $54.0^{\mathrm{c}}$ & $66.0^{\mathrm{b}}$ & 31.4 & * \\
\hline GIT empty (g) & 1900.0 & 1633.3 & 1611.3 & 2215.0 & 1779.3 & 1633.3 & 330 & ns \\
\hline Tail fat (g) & 987.3 & 951.0 & 1106.7 & 920.0 & 1151.3 & 1213.3 & 100.9 & ns \\
\hline \multicolumn{9}{|c|}{ II. Non-edible non-carcass traits } \\
\hline Skin (g) & $3600.0^{\mathrm{a}}$ & $3766.7^{\mathrm{a}}$ & $3700.0^{\mathrm{a}}$ & $3133.3^{\mathrm{b}}$ & $5100.0^{c}$ & $5033.3^{c}$ & 255.0 & $* *$ \\
\hline Head (g) & $1773.3^{\mathrm{a}}$ & $1733.3^{\mathrm{a}}$ & $2110.0^{\mathrm{b}}$ & $2206.7^{\mathrm{b}}$ & $2660.0^{c}$ & $2763.3^{\mathrm{c}}$ & 134.9 & $* *$ \\
\hline Testicle (g) & $420.0^{\mathrm{a}}$ & $420.0^{\mathrm{a}}$ & $310.0^{\mathrm{b}}$ & $310.0^{\mathrm{b}}$ & $540.0^{\mathrm{a}}$ & $430.0^{\mathrm{a}}$ & 56.0 & $* * *$ \\
\hline Blood (g) & $1336.7^{\mathrm{a}}$ & $1300.0^{\mathrm{a}}$ & $873.3^{\mathrm{b}}$ & $937.3^{\mathrm{b}}$ & $2033.3^{c}$ & $1823.3^{\mathrm{c}}$ & 181.3 & ** \\
\hline Bladder (g) & $67.3^{\mathrm{a}}$ & $68.7^{\mathrm{a}}$ & $57.3^{\mathrm{b}}$ & $63.3^{\mathrm{b}}$ & $72.3 .0^{\mathrm{a}}$ & $64.0^{\mathrm{a}}$ & 2.3 & $* *$ \\
\hline Feet $(\mathrm{g})$ & $247.7^{\mathrm{a}}$ & $249.7^{\mathrm{a}}$ & $214.0^{\mathrm{a}}$ & $194.7^{\mathrm{b}}$ & $203.7^{\mathrm{b}}$ & $217.7^{\mathrm{a}}$ & 16.4 & ${ }^{*}$ \\
\hline Digestive content (g) & $8400.0^{c}$ & $8300^{c}$ & $4222.0^{a}$ & $5551.7^{\mathrm{b}}$ & $3466.7^{a}$ & $4337.3^{\mathrm{a}}$ & 725.2 & $* *$ \\
\hline Spleen (g) & 41.7 & 44.0 & 32.7 & 45.0 & 33.7 & 30.3 & 4.7 & ns \\
\hline
\end{tabular}

Table 7 .

Genotype and diet effects on edible and non-edible non-carcass components. 
Body Weight Gain and Carcass Yield Characteristics of Wollo Highland Sheep and Their...

DOI: http://dx.doi.org/10.5772/intechopen.92340

[21] for Chilote and Suffolk breeds in Chile Island. The chilling loss of cold carcass weight may vary between 1 and 7\%, usually found close to 2.5\% [22]. Moreover, sex, weight, fat covering of the carcass, temperature, and humidity in the cold storage chamber and the handling of the carcasses [23,24] influence cold carcass characteristic.

Dressing percentage is described as the proportion of carcass weight to slaughtered body weight and it helps to assess meat productivity of the animals. Nutrition influences dressing percentage through variation in weight of mesentery contents and variation in actual organ weights $[25,26]$. In agreement with the present finding, Awgichew [10] reported, regardless of the clear tendency of Horro lambs having a heavier hot and cold carcass weight, but did not differ significantly from Menz breed in dressing \% and the loss of carcass moisture (shrinking \%) after an overnight cooling. The present finding reported, hot carcass weight dressing percentage (HCCWDP) does not have significant difference both between and within genotype and which in agreement with Awgichew [10] and Jorge et al. [21]. Concurring with this report, an experimental trial conducted by Mazemder et al. [27] on grazing local sheep supplemented and with non-supplemented of 100, 200 and $300 \mathrm{~g}$ of concentrate feed/day; dressing percentage was similar among the treatments.

Rib-eye muscle area is mostly used as a tool to indicate the proportion of carcass muscling $[28,29]$. In the present study the supplementation diet did not have a significant impact on rib-eye muscle area but numerical difference was observed. In line with the current finding, Gizaw [1] reported supplementation did not have significant effect on rib-eye muscle area in Somali goats fed hay and supplemented with different levels of peanut cake and wheat bran mixture. However, unlike this finding, Matiwas et al. [28] and Alemu [32] reported supplementation diet had a significant and positive effect on rib-eye muscle area. In concurrence with this finding, Matiwas et al. [31], Alemu [32]; Simret and Gizaw [30] reported rib-eye area had a significant variation between breeds. However, did not significant variation between supplemented and non-supplemented groups of Awassi crosses and Wollo highland breed lambs (Table 7). Nevertheless, supplemented and nonsupplemented groups of Washera crossbreds had significant differences of rib-eye area composition. This fact is an indicator of better muscle development of supplementing Washera crosses than non-supplemented one. Hence, this rib-eye area muscle development is one of the merits to select Washera $F_{1}$ crossbred lambs for meat production objective. Both supplemented and non-supplemented Wollo highland and non-supplemented Washera crossbred lambs have relatively comparable rib-eye area muscle development (Table 7).

Except dressing percentage, almost all carcass characteristic extent both supplemented and non-supplemented Awassi crossbred had significantly higher than Wollo highland and Washera $\mathrm{F}_{1}$ crossbred lambs. Hence, crossbreeding effect on genetic improvement practices using Awassi exotic breed had significant response associated with growth and carcass yield characteristic traits. As a result Awassi $F_{1}$ crossbred lambs had potential effect on meat production improvement objective and advisable to be selected for further breed productivity improvement program.

\subsection{Genotype and supplemented feed effects on non-carcass fat distribution}

The effects of genotype and supplementation diet on non-carcass fat distribution was presented in Table 6. Thus, non-carcass fat contents around the scrotal organ had not significant variation between supplemented and non-supplemented groups of the three genotypes. However, between Wollo highland breed lambs and Awassi $\mathrm{F}_{1}$ crossbred lambs, significant variation of fat around scrotal organ observed. 
Likewise, between supplemented and non-supplemented groups of Washera and Awassi $\mathrm{F}_{1}$ crossbred lambs have significant difference fat around scrotal organ recorded. Subcutaneous fat content between Wollo highland and Awassi crossbred lambs had comparable value. However, Awassi crossbred and Wollo highland breed lambs significantly lower subcutaneous fat content than Washera crossbred lambs. The reason behind this, on fat deposition efficiency of Washera $\mathrm{F}_{1}$ crosses genotype effect has more noticeable than Awassi crosses and Wollo highland breed.

The current study showed mesentery fat, kidney fat and subcutaneous fat decreased in non-supplemented ram lambs fed on natural pasture forage diet only. The current result is in agreement with reported by Karim et al. [33] and Papi et al. [34] on the concept of lambs with high forage quality tended to deposit less subcutaneous and intestinal fat contents. Lambs fed a concentrate diet displayed considerably greater fat accumulation than lambs raised on forage based diets [35]. The reduced non-carcass fat attributed to lower energy intake from forage [33]. In addition, high starch consumption the supplemented concentrate diets produces higher amounts of propionate, which ultimately increases insulin secretion and stimulates fat synthesis [35]. In agreement with this finding, Ibrahim et al. [29], Salo et al. [36], Roberto et al. [37] and Abebe and Tamir [38] reported the total fat contents of non-carcass components were significantly affected by the type of diet used. However, in the current finding, in addition to the effects of diet, genotype effects also significant $(\mathrm{P}<0.05)$ different on total non-carcass fat contents. Even though, supplemented Awassi and Washera crossbred lambs had comparable total non-carcass fat composition, Washera $\mathrm{F}_{1}$ crossbred lambs showed comparatively higher fat contents than Awassi $\mathrm{F}_{1}$ crossbreds in relation to their body weight difference.

\subsection{Genotype and supplemented feed effects on edible and non-edible, non-carcass part}

Accordingly, intellectual prohibited cultural and religious taboo of local communities, edible components of non-carcass organs, which presented as liver, tongue, heart, kidney, empty gastrointestinal content and tail fat are the most common and presented in Table 6. Hence, liver and heart weight comparable value between Wollo highland and Washera crossbred lambs; however, Awassi crossbred lambs had significantly $(\mathrm{p}<0.05)$ higher than the other. The reason behind this might be larger body size and physiological appearance of the genotype. However, non-significant variation between supplemented and non-supplemented groups of all genotypes were recorded, while the kidney and intestine weight had a comparable amount for all genotypes and feeding type. Roughage part of animal feed obvious to feel rumen content and the the green forge grazing was equally accessible to all genotypes and which was the reason for comparable intestinal weight. Whereas the tail size had comparable value for Awassi crossbred and Wollo highland breed ram lambs, Washera crossbred lambs had a significantly $(\mathrm{P}<0.05)$ larger tail size than other two genotypes. This also indicated that Washera $\mathrm{F}_{1}$ crossbred ram-lambs shown larger fat development nature and that might be because of largest tail weight.

In agreement with current finding, Riley et al. [39] and Teklu [40] were reported the majority of edible offal components was not affected $(P>0.05)$ by the supplemented feed. As a remarkable feature of Awassi crossbred lambs more advanced with liver, tongue and heart weight. This perceptible difference resulted from large body size and genotype effect. In concurrence with the current result, Riley et al. [39] indicated that differences in internal organs were more influenced by age, breed and sex of the animals rather than plane of nutrition, whereas kidney and empty gastrointestinal track weight cover the larger portions of edible non- 
Body Weight Gain and Carcass Yield Characteristics of Wollo Highland Sheep and Their...

DOI: http://dx.doi.org/10.5772/intechopen.92340

carcass components compared with all genotypes, which aligned with Teklu [40]. This implies animals consume more feed, their stomach enlarged to accommodate the larger ingesta and thicker to resist the workload on it and this may increase the volume and weight of the gastrointestinal tract as a whole.

Except lung with trachea and spleen, all non-edible offal components were not affected by supplemented diet and indicating that variation of supplementation diet not influenced the non-edible non-carcass components. The non-edible non-carcass contents of head, digestive content and blood volume significant difference $(\mathrm{p}<0.05)$ among genotypes and this might be slaughtered body weight differences and the inherent genotype effect. In agreement with the current study, Prasad and Kirton [41] reported live weight status of the animals could affect the production efficiency of carcass offal and considered as depressing factor for hot and cold carcass weight extent and their dressing percentage. However, the nutritional effect not significantly visible for most non-edible non-carcass component weight and which in agreement with Teklu [40] but disagree with Michael and Yaynshet [42]. In general the larger extent of non-carcass non-edible components could be reduced the edible carcass and non-carcass amount, hence, through breed selection task, need to be considered the non-carcass non-edible content of genotype.

\section{Conclusion and recommendation}

The study conducted at feedlot productive performance evaluation of Wollo highland sheep breed and their $\mathrm{F}_{1}$ crossbreeds of Awassi and Washera sheep in Ethiopia. The objectives of the research is grazing and feedlot based productive performance evaluation of Wollo highland sheep breed and their $\mathrm{F}_{1}$ crosses.

The average daily weight gain (ADG), total body weight change and final body weights of supplemented group Awassi $\mathrm{F}_{1}$ crossbred and Wollo highland ram lambs significantly higher than non-supplemented groups. Awassi $\mathrm{F}_{1}$ crossbred lambs growth performance significantly higher than Wollo highland and Washera $\mathrm{F}_{1}$ crossbred lambs and followed by supplemented Wollo highland breed lambs. Wollo highland breed had ability to increase their body weight compared with other selected indigenous breed types of the country and have potential value for fattening purpose and productive potential genetic improvement practice, as far as their nutritional requirement is maintained.

The effect of genotypes on average daily weight gain of Awassi crossbred ram lambs had the largest value of breed selection in the current study. Therefore, the effect of both genotype and supplementation diet have an advanced value for lamb body weight gain improvement practices. Moreover, cost effective concentrate feed supplementation on natural pasture controlled grazing have to give appropriate attention by smallholder sheep producers and fatteners.

Carcass composition used as a tool to characterize breeds for possible identification of potential genetic resource of lean meat type of lamb production and identify management alternatives to suit different breeds. Differences in carcass merits between genotypes are likely to govern the choice and development of breeds for specific production objective. Natural pasture controlled grazing management important alternative for productive and organic product improvement practices.

Supplementation diet does not have significant effect on hot carcass weight dressing percentage however, further research is important to confirm at different level of supplementation feeding trial. Cold carcass weight dressing percentage (CCWDP) has a significant difference between supplemented and nonsupplemented groups of each of the three genotype in the present study and its important parameter for carcass productivity improvement practice. 
Awassi $\mathrm{F}_{1}$ crossbred progenies designated for promising attributes for higher body weight gain and carcass yield characteristics productive trait and good fertility rate; however, further research verification activities suggested with different blood level of crossbred progenies performance evaluation. The genotype and supplementation diet effect has profound factors to enhance productive and farmers' production objectives decision. Hence, researchers need to investigate farmers' interest and potential of available breed type through genetic and phenotype performance study. Effective concentrate feed supplementation on controlled natural pasture grazing had significant impact on ram lambs productive performance improvement and it is crucial to create appropriate understanding for fatteners, traders and other sheep producers.

\section{Acknowledgements}

Mehamed Ali (private sheep farm owner) and Dessie Zuria District smallholder farmers have participated with allowed their sheep flocks for inventory purpose. Medhin G/Cherkos, Tadesse Mergiaw, Tilahun Gezahegn and Ayiten Mekete participated through data collection as enumerator. Addis Ababa (AAU) and Wollo University (WU) have participated in providing Research Grant. Department of Animal Production Study (DAPS) in Addis Ababa University, participated through assistance from the beginning to the end of data collection process and the whole thesis work.

\section{Conflict of interest}

The authors declare no conflict of interest.

\section{Funding}

The work of this research project has done by the funding support of Addis Ababa University thematic project, Minister of Education, and Wollo University collaboration.

\section{Abbreviations}

CSA Central Statistics Authority

EPA extension planning area

SPS sanitary and phytosanitary standards

UNCTD United Nations Conference on Trade and Development 
Body Weight Gain and Carcass Yield Characteristics of Wollo Highland Sheep and Their... DOI: http://dx.doi.org/10.5772/intechopen.92340

\section{Author details}

Tadesse Amare Sisay ${ }^{1 *}$, Gebeyehu Goshu Negia ${ }^{2}$ and Berhan Tamir Mersso ${ }^{2}$

1 Department of Animal Science, College of Agriculture, Wollo University, Dessie, Ethiopia

2 Department of Animal Production Studies, College of Veterinary Medicine and Agriculture, Addiss Ababa University, Bishoftu, Ethiopia

*Address all correspondence to: tadesse.amare2002@yahoo.com

\section{IntechOpen}

(C) 2020 The Author(s). Licensee IntechOpen. This chapter is distributed under the terms of the Creative Commons Attribution License (http://creativecommons.org/licenses/ by/3.0), which permits unrestricted use, distribution, and reproduction in any medium, provided the original work is properly cited. (cc) BY 


\section{References}

[1] Gizaw S, Johan A, Olivier H, Hans K, Johann S, Dessie T, Van der Z,

Herbert $H$. Sheep resources of Ethiopia: Genetic diversity and breeding strategy [PhD thesis]. Wageningen, the Netherlands: Wageningen University; 2008a

[2] CSA. Agricultural Sample Survey, 2012, Volume II: Report on Livestockand Livestock Characteristics (Private Peasant Holdings) Statistical Bulletin 585. Addis Ababa, Federal Democratic Republic of Ethiopia: CSA; 2017

[3] Hirpa A, Abebe G. Economic significance of sheep and goats. In: Yami A, Merkel RC, editors. Sheep and Goat Production Handbook for Ethiopia. Ethiopia, Addis Ababa: Ethiopia Sheep and Goat Productivity Improvement Program (ESGPIP); 2008; pp. 1-4

[4] Bogale S, Melaku S, Yami A. Matching livestock systems with available feed resources in the Bale Highlands of Ethiopia. Outlook Agricultural Journal (OAJ). 2008;37: 105-110

[5] Mukasa-Mugerwa E, Lahlou-Kassi A. Reproductive performance and productivity of Menz sheep in the Ethiopian highlands. Journal of Small Ruminant Research (JSRR). 1995;17: 167-177

[6] Dejene A. Integrated Natural Resources Management to Enhance Food Security: The Case for Community-Based Approaches in Ethiopia. Working Paper No. 16. Rome, Italy: FAO; 2003

[7] Yeheyis L, Sebsibe A, Girma A. On-farm evaluation of the effect of supplementing grazing Menz sheep during the dry season in Gerakeya Woreda, North Sea. In: Proceedings of the 12th Annual Conference; 12-14
August. Addis Ababa, Ethiopia; 2004. pp. $371-375$

[8] Tibbo M. Productivity and health of indigenous sheep breeds and crossbreds in the central Ethiopian highlands $[\mathrm{PhD}$ dissertation]. Uppsala, Sweden: Swedish University of Agricultural Sciences; 2006. pp. 11-63

[9] Gatenby RM. Sheep Production in the Tropics and Subtropics. New York: Longman Inc.; 1986. p. 351

[10] Awgichew K. Comparative performance evaluation of Horro and Menz sheep of Ethiopia under grazing and intensive feeding conditions [PhD dissertation]. Berlin, Germany:

Humboldt University; 2000

[11] Parker WJ, McCutcheon SN, Wickham GA. Effect of administration and ruminal presence of chromic oxide controlled release capsules on herbage intake of sheep. New Zealand Journal of Agricultural Research (NZJAR). 1991; 34:193-200

[12] Hammell K, Laforest J. Evaluation of the growth performance and carcass characteristics of lambs produced in Quebec. Canadian Journal of Animal Science. 1999;71:68-74. Available from: www.nrcresearchpress.com

[13] Notter DR, Copenhaver JS. Performance of Finnish Landrace crossbred ewes under accelerated lambing. Journal of Animal Science (JAS). 1980;51(5):1043-1050

[14] Burfening PJ, Kress DD. Direct and maternal effects on birth and weaning weight in sheep. Journal of Small Ruminant Research (SRR). 1993;10: 153-163

[15] Bathaei S, Leroy P. Growth and mature weight of Mehraban Iranian fat 
Body Weight Gain and Carcass Yield Characteristics of Wollo Highland Sheep and Their...

DOI: http://dx.doi.org/10.5772/intechopen.92340

tailed sheep. Journal of Small Ruminant Research (JSRR). 1996;22:155-162

[16] Snowder GD, Glimp HA, Field R. Carcass characteristics and optimal slaughter weights in four breeds of sheep. Journal of Animal Science (JAS). 1994;72:932-937

[17] Orr RM. Animal production, animal physiology. In: Haley RT, editor. The Agricultural Note Book. 17th ed.

London: Butterworths and Co. (Publishers) Ltd.; 1982. pp. 305-318

[18] Lakew M, Haile-Melekot M, Mekuriaw G. Evaluation of growth performance of local and Dorper $\times$ local crossbred sheep in eastern Amhara region, Ethiopia. Iranian Journal of Animal Science. 2014;4:123-126

[19] Assefu G. Comparative feedlot performance of Washera and Horro sheep fed different roughage to concentrate ratio [MSc thesis]. Diredawa, Ethiopia: Haramaya University; 2012

[20] Taylor SC, Murray JI, Thonney ML. Breed and sex differences between equally mature sheep and goats, carcass muscle fat and bone. Journal of Animal Production (JAP). 1989;49:385-409

[21] Jorge RR, Rodrigo M, Eugenia M, Rodrigo B. Effect of breed and feeding on the carcass characteristics of the Chilote breed lamb. Chilean Journal of Agricultural Research (CJAR). 2013;73(1). version On-line ISSN: 0718-5839; DOI: 10.4067/S071858392013000100007

[22] Walstra P, de Greef KH. Aspects of development and body composition in pigs. In: Ender K, editor. Proceedings of 2nd Dummerstorf Muscle Workshop. Muscle growth and Meat Quality; 1995; Rostock. 2nd ed. 1995. pp. 183-190

[23] Moreno G, Loureiro C, Souza H. Carachterísticas of qualitative ovina.
Journal of Revista Nacional da Carne, São Paulo (JRNDCSP). 2008;1(381): 76-90

[24] Rozanski S, Vivian DR, Kowalski LH, Rogerio PO,

Fernandes SR, Souza JC, et al. Carcass and meat traits and non-carcass components of lambs fed ration containing increasing levels of urea. Journal of Ciências Agrárias (JCA). 2017;38(3):1577-1593

[25] Warmington BG, Kirton AH. Genetic and non-genetic influences on growth and carcass traits of goats. Journal of Small Ruminant Research (JSRR). 1990;3:147-165

[26] Payne WJ. An Introduction to Animal Husbandry in the Tropics. Vol. 44. New York, United States: Longman Scientific and Technical; 1999.

pp. 233-240

[27] Mazemder MA, Hossain MM, Khter SA. Effect of levels of concentrate supplement on live weight gain and carcass characteristics in sheep on restricted grazing. Journal of Animal Science (JAS). 1998;11:17-20

[28] Mathios S, Solomon M, Adugna T. The effect of different level of cotton seed cake supplementation on feed intake, digestibility body weight change and carcass parameter of Sidama goats. Journal of Livestock Science (JLS). 2008;119:137-144

[29] Ibrahim A, Mutassim M, Abdullah H, Rifat U, Mohamed Y, Al-Saiady R, et al. Effect of alfalfa hay on growth performance, carcass characteristics, and meat quality of growing lambs with ad-libitum access to total mixed rations. Journal of Revista Brasileira de Zootecnia (JRBZ). 2016; 45(6):302-308

[30] Smachew G. Effects of supplementation with maize bran, noug seed cake (Guizotia abyssinica) and their 
mixtures on feed utilization and carcass characteristics of Washera sheep fed hay [MSc thesis]. Ethiopia: Haramaya University; 2009. pp. 33-41

[31] Wolf BT, Smith C, Sales DI. Growth and carcass composition in the crossbred progeny of six terminals sire breeds of sheep. Journal of Animal Production (JAP). 1980;31:307-313

[32] Alemu W. Effects of supplementing hay from natural pastures with oil seed cakes on feed intake, digestibility and body weight change of Sidama goats [MSc thesis]. Ethiopia: Haramaya University; 2008. p. 62

[33] Karim SA, Powell K, Kumar S, Singh V. Carcass traits of Kheri lambs maintained on a different system of feeding management. Journal of Meat Science (JMS). 2007;76:395-401

[34] Papi N, Mostafa-Tehrani A, Amanlou H, Memarian M. The effects of dietary forage-to-concentrate ratios on performance and carcass characteristics of growing fat-tailed lambs. Journal of Animal Feed Science and Technology (JAFST). 2011;163:93-98

[35] Jacques J, Berthiaume R, Cinq-Mars D. Growth performance and carcass character rustic of Dorset lambs fed different concentrates, forage rations or fresh grass. Journal of Small Ruminant Research (JSRR). 2011;95:113 -11

[36] Salo S, Urge M, Animut G. Effects of supplementation with different forms of barley on feed intake, digestibility, live weight change and carcass characteristics of Hararghe highland sheep fed natural pasture. Journal of Food Processing Technology (JFPT). 2016;7(3):2157-7110

[37] Roberto GC, José T, Wandrick H, Severino GN, Marta SM, Angelina BF. Effect of diet and genotype on carcass characteristics of feedlot hair sheep. Journal of Revista Brasileira de
Zootecnia (JRBZ). 2010;39(12): 2763-2768

[38] Abebe H, Tamir B. Effects of supplementation with pigeon pea (Cajanus cajan), cowpea (Vigna unguiculata) and lablab (Lablab purpurium) on feed intake, body weight gain and carcass characteristics in Wollo sheep fed grass hay. International Journal of Advanced Research Biological Science (IJARBS). 2016;3(2):280-295

[39] Riley RR, Savell JW, Shelton M, Smith GC. Carcass and offal yields of sheep and goats as influenced by market class and breed. Journal of Small Ruminant Research (JSRR). 1989;2(3): 265-272

[40] Teklu WF. The effects of feeding different varieties of faba bean (Vicia faba L.) straws with concentrated on feed intake, digestibility, body weight gain and carcass characteristics of ArsiBale sheep [MSc thesis]. Ethiopia: Haramaya University; 2016

[41] Prasad V, Kirton S. Carcass and non-carcass traits of Muzaffarnagri lambs at different maturity levels. Indian Journal of Animal Science (IJAS). 1992;62(2):159-164

[42] Michael Y, Yaynshet T. Feed utilization, digestibility and carcass parameters of Tigray highland sheep fed wheat straw supplemented with mixtures of wheat bran and cotton seed cake, in Tigray, Ethiopia. Journal of ABC Research Alert (JABCRA). 2014;2(1):12-15 


\title{
Use of Computed Tomography and Thermography for the Diagnosis of Respiratory Disorders in Adult Sheep
}

\author{
Luis Miguel Ferrer, Juan José Ramos, Enrique Castells, \\ Héctor Ruíz, María Climent and Delia Lacasta
}

\begin{abstract}
Respiratory diseases are one of the main causes of death and economic losses in sheep farming. The prevention and treatment of these diseases must be based on a correct diagnosis, which improves the results of health plans and optimizes the responsible use of medicines. Diagnostic imaging techniques are important working tools to diagnose this kind of disorders but have not always been sufficiently used in sheep. X-ray, although widely used in small animals, is not a valuable tool in field conditions. Ultrasonography is a noninvasive technique easily applied in sheep farms and very useful for the diagnosis of respiratory diseases; however, many articles have been already published on this topic. The present paper proposes and illustrates the use of thermography and computed tomography (CT) to support and improve the aforementioned techniques, taking into consideration that thermography is only useful for upper respiratory tract disorders and CT scan is an expensive technique for routine use but very illustrative to understand the pathogenesis of the different disorders and to improve the in vivo diagnosis.
\end{abstract}

Keywords: thermography, computed tomography, sheep, respiratory diseases

\section{Introduction}

The respiratory system consists of a series of organs responsible for performing a set of physical and chemical processes that aim to absorb the air oxygen $\left(\mathrm{O}_{2}\right)$, essential for the oxidative phenomena that occur in the tissues, and the elimination of products resulting from these same oxidative phenomena, especially carbon dioxide $\left(\mathrm{CO}_{2}\right)$ [1]. The airways begin in the nares or external nasal openings and end at the level of the terminal bronchi, already within the lungs. These airways include an upper respiratory tract (nasal cavity, paranasal sinuses, nasopharynx, and larynx) and a lower respiratory tract (trachea and lung). This classification will be used to describe the respiratory disorders in this paper.

The development of effective health plans and the optimization of the use of drugs require an accurate diagnosis that assures that the treatment is addressed against the cause responsible for the pathological process. In this sense, diagnostic 
imaging is a useful tool based on noninvasive techniques that provide images for the correct diagnosis of the different disorders. Although there are a wide variety of diagnostic imaging techniques appropriate for the diagnosis of respiratory disorders, this article focusses only on infrared thermography and computed tomography. Others such as radiography or ultrasound are not described here because there is an extensive series of published papers on these techniques.

Infrared thermography is an innovative noninvasive tool that allows the remote measurement of the surface temperature of an animal. A thermal imaging camera captures and records the measurement and creates a color thermal image, where each color corresponds to a specified temperature [2]. A computer program, associated with the camera, allows measuring the temperature of each point in the image and thus compares the different areas. There are different patterns of colors that can be chosen; in our case we will use the pattern that associates cold temperatures with blue, turning to green, yellow, orange, red, and white as the temperature of the area rises. Colors are not directly associated with the degrees of temperature; simply, the coldest area of the image is related to the blue color and the hottest area to the white color, whatever those temperatures are.

These properties make it especially useful for diagnosing upper respiratory tract diseases, where the internal temperature of the affected structures in the nasal cavities and sinuses comes to modify the surface temperature of the face. The generated image allows comparison of the left and right side of the animal, detecting which side is affected and if it produces changes in the ventilation of the nostrils. In winter, the cold air that the sheep breathes cools down the nostrils, and the diagnosis of the different disorders that hinder the passage of air is straightforward; however, with external high temperatures, closer to body temperature, it is more difficult to detect these changes. Nevertheless, the immediacy and the current low prices of the thermal cameras make the use of thermography suitable as one of the first tests to be carried out to diagnose upper respiratory tract diseases in sheep.

Computed tomography, also known as CT scanner, is also based on the variable absorption of X-rays by different tissues. However, CT provides a different form of imaging known as cross-sectional imaging. Therefore, this system provides images that are similar to anatomical sections of the structure of the animal studied. Different computer programs associated with the scanner allow obtaining axial, sagittal, and coronal sections. Also, it is possible to make color three-dimensional reconstructions of the studied area and to be able to introduce or remove different densities, which is equivalent to being able to observe different structures. In the case of the respiratory system, these programs allow us to eliminate all the structures and only leave the image of the surface of the airways, which is equivalent to having the negative image of the respiratory tree. Currently, CT scanner is only used with research purposes or for complex diagnosis in sheep; however, it is very valuable to understand the different respiratory diseases and their pathogenesis and evolution.

This article shows comparative images obtained by CT scan and thermography with those taken later at the necropsies of the animals. More than 80 respiratory clinical cases affecting adult sheep received at the Ruminant Clinical Service of the Veterinary Faculty of Zaragoza (SCRUM) have been studied using CT scan and thermography as imaging diagnostic tools. Subsequently, a postmortem examination was performed in all the cases. The final diagnosis was supported by histopathological, microbiological, and biomolecular analyses of the respiratory system of the studied animals.

To capture the images shown in this article, the used devices were the following:

- Thermographic camera: FLIR E63900, T198547. Images were performed at the Ruminant Clinical Service of the Veterinary Faculty of Zaragoza, Spain. 
Use of Computed Tomography and Thermography for the Diagnosis of Respiratory Disorders... DOI: http://dx.doi.org/10.5772/intechopen.92615

- Computed axial tomography: General Electric Healthcare. The CT scan model is: CT Brivo 325, General Electric. Images were performed at the Centro Clinico Veterinario of Zaragoza, Spain. The RadiAnt DICOM Viewer 4.6.9 program was used to analyze the images.

\section{Respiratory tract disorders}

\subsection{Upper respiratory tract disorders}

The upper airways provide an intricate space for filtration, tempering, and humidification of inspired air. There are a whole series of structures that can be affected by different pathological disorders. Dorsal, ventral, and medium turbinates and ethmoidal labyrinth are easily examined through thermography, this being of great relevance because there are several diseases that settle in these structures hindering or obstructing the passage of air.

Before starting with the description of the diseases that affect the upper respiratory tract, thermography and CT scan of these structures in a healthy animal will be shown. Therefore, the comparison between healthy and affected animals can be more easily understood.

In Figure 1, a zenith view of the head of a healthy sheep can be observed with air passing through the nostrils, cold in winter (Figure 1a) and warm in summer (Figure 1b). Figure 2 shows a cross section of the head at the level of the second molar, where the internal structure of the ventral and dorsal turbinates can be seen both at necropsy (Figure 2a) and with tomographic images with and without an Airways filter (Figure $\mathbf{2 b}$ and $\mathbf{c}$ ). In Figure $3 \mathbf{a}$ sagittal cut of the head avoiding the

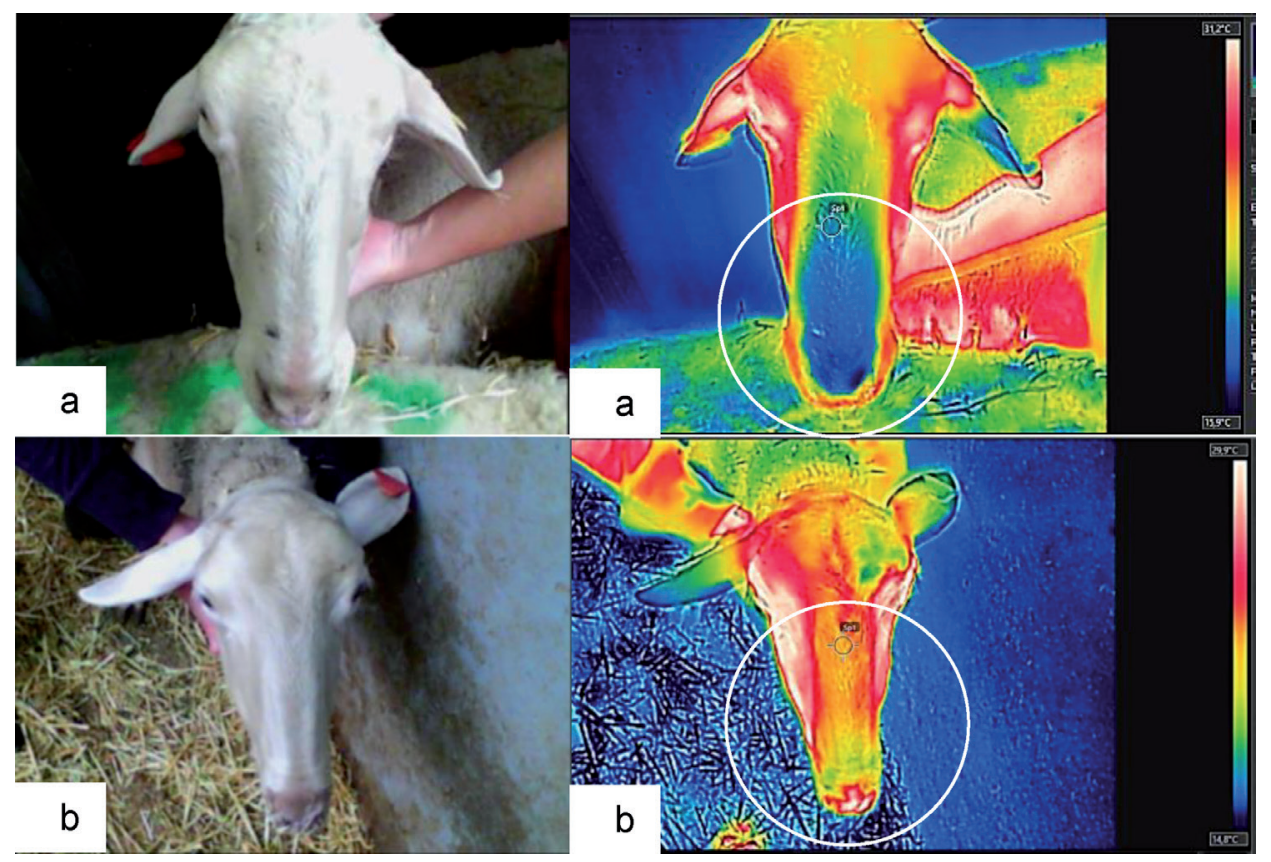

Figure 1.

Zenith view of the head of a healthy ewe. (a) Picture of the ewe's head and its thermographic image with symmetrical cooling of the nostrils with cold external temperature (cold colors = blue and green). (b) Ewe's head picture and its thermography with symmetrical cooling of the nostrils with warm external temperature (warm colors $=$ yellow and light green $)$. 


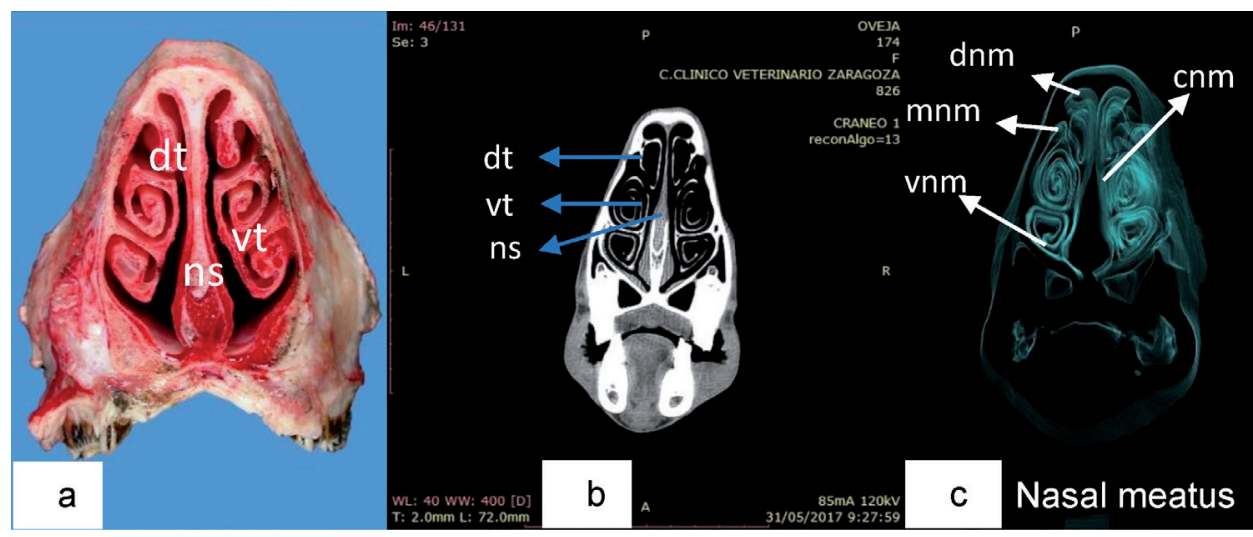

Figure 2.

Nasal cavity of a healthy ewe. (a) Axial section of the head at the level of the second molar (dt dorsal turbinate, vt ventral turbinate, ns nasal septum). (b) CT axial view at maxillary sinus level (dt dorsal turbinate, vt ventral turbinate, ns nasal septum). (c) CT axial $3 D$ view with airways filter. Surfaces view delimiting the air ducts or nasal meatus (cnm—common nasal meatus, dnm—dorsal nasal meatus, mnmmedium nasal meatus, vnm-ventral nasal meatus).

nasal septum with the structures of all turbinates can be seen (Figure 3a-c). The spatial placement of the different airways within the bone structure of the skull is appreciated.

Paranasal sinuses (maxillary, frontal, and lacrimal) and nasal septum have less diagnostic importance due to their low frequency of injury. Figure 4 shows an axial section of the head at the level of the ethmoidal turbinate where the lacrimal paranasal sinuses can be seen (Figure $\mathbf{4 a}$ and $\mathbf{b}$ ). Sporadically, alterations of the pharynx and larynx are diagnosed.

Below we will explain the different disorders that affect the upper respiratory tract in sheep and how imaging techniques can help in their diagnosis.

\subsubsection{Chronic proliferative rhinitis}

Chronic proliferative rhinitis (CPR) is an upper respiratory tract disease of sheep associated with Salmonella enterica subsp. diarizonae serovar 61:k:1,5,(7) (SED) which was described for the first time in the United States in 1992 [3] and, subsequently, in Spain [4, 5], again in the United States [6] and Switzerland [7]. In addition, it has also been diagnosed in the United Kingdom and Brazil (personal communications).

SED is a saprophytic microorganism in sheep; however, when this bacterium becomes intracellular, it produces an intense inflammatory reaction in the ventral turbinate, giving rise to the classical clinical signs of the disease [5]. This fatal prognosis disease causes loss of weight, no fever, snoring, seromucous nasal secretion, and nasal deformation. It can be unilateral or bilateral and regional lymph nodes are usually enlarged. Over time, these signs get worse, and, sometimes, it is possible to see inflammatory proliferative tissue at the nares $[4,5,7]$. Further, the inadequate flow of air in affected animals provides a better situation for opportunistic bacteria that lead to secondary pulmonary diseases that usually are responsible for the final death of the animals [5].

At postmortem examination, the ventral turbinates are presented swollen with a roughened surface (Figure 5a). The section of the turbinate shows a proliferative tissue that is usually composed of multiple small white or yellow polypoid structures covered by mucus, although, sometimes, only a thickening of the mucosa 
Use of Computed Tomography and Thermography for the Diagnosis of Respiratory Disorders... DOI: http://dx.doi.org/10.5772/intechopen.92615

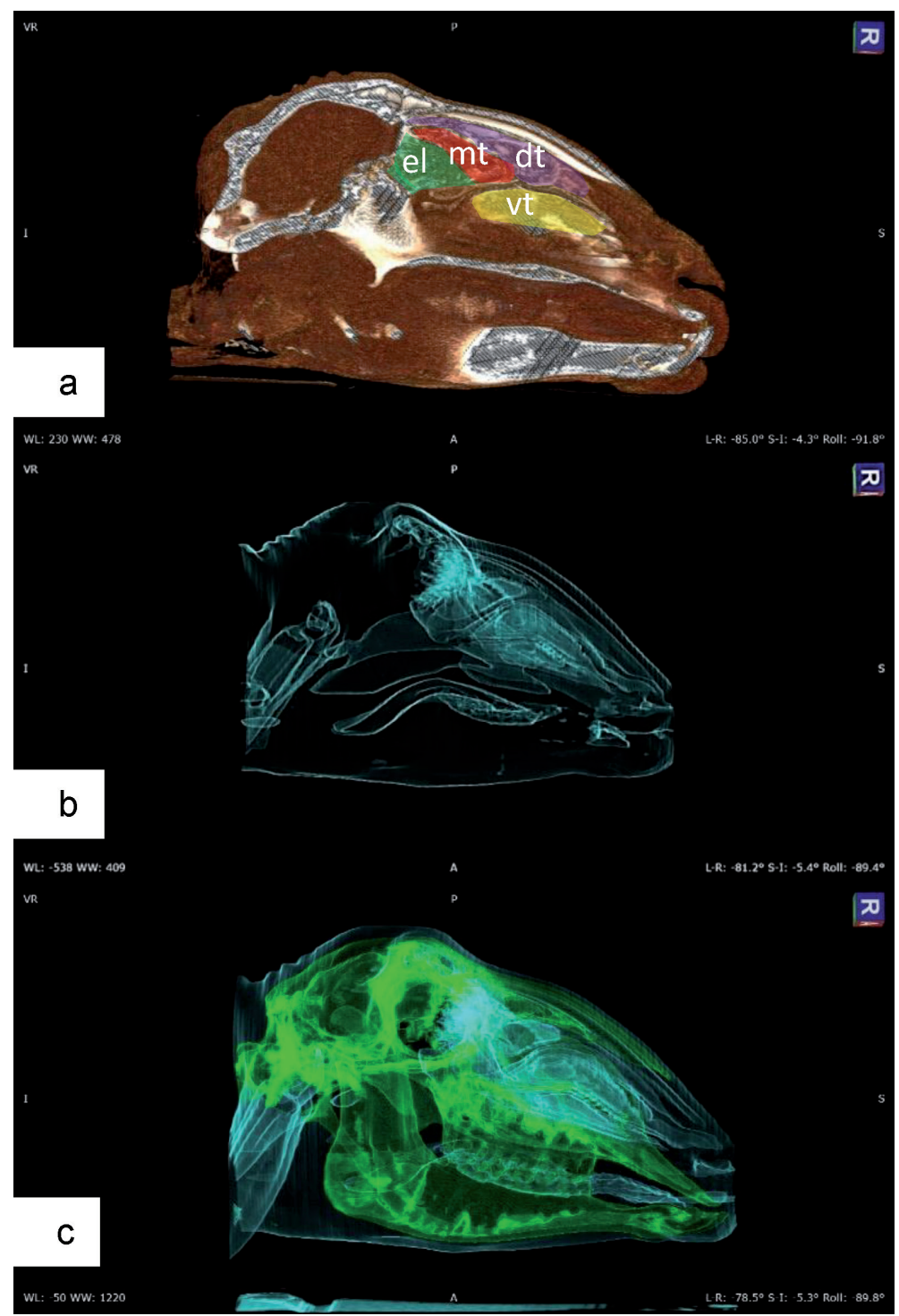

Figure 3.

$C T_{3} D$ sagittal views of a healthy ewe. (a) Sagittal cut of the head avoiding the nasal septum. The structures of all turbinates (dt dorsal turbinate, $m$ t medium turbinate, vt ventral turbinate, and el ethmoidal labyrinth) are highlighted. (b) The same cut as 3 a with airways filter to show the areas with air (blue). (c) Sagittal section with filter for airways (blue) and bone (green). The spatial placement of the different airways within the bone structure of the skull is appreciated.

can be observed [4]. Occasionally, the dorsal and medium turbinates may also be affected [8].

Thermographic images of CPR cases detect high temperatures (white and red colors) in the nostril area corresponding to the swollen ventral turbinate, and the difficulty of ventilation of the nasal cavity can also be observed (Figure 5b).

Computed tomography enables to obtain a clear image of the damaged tissue and the different stages of development of the disease (Figure 6). It also shows the increase in size of swollen turbinates and the bone destruction in more advanced cases. Axial slides show uni- or bilateral lesions, while sagittal slides detect affected turbinates, generally the ventral and less frequently the dorsal (Figure 6a-d). 


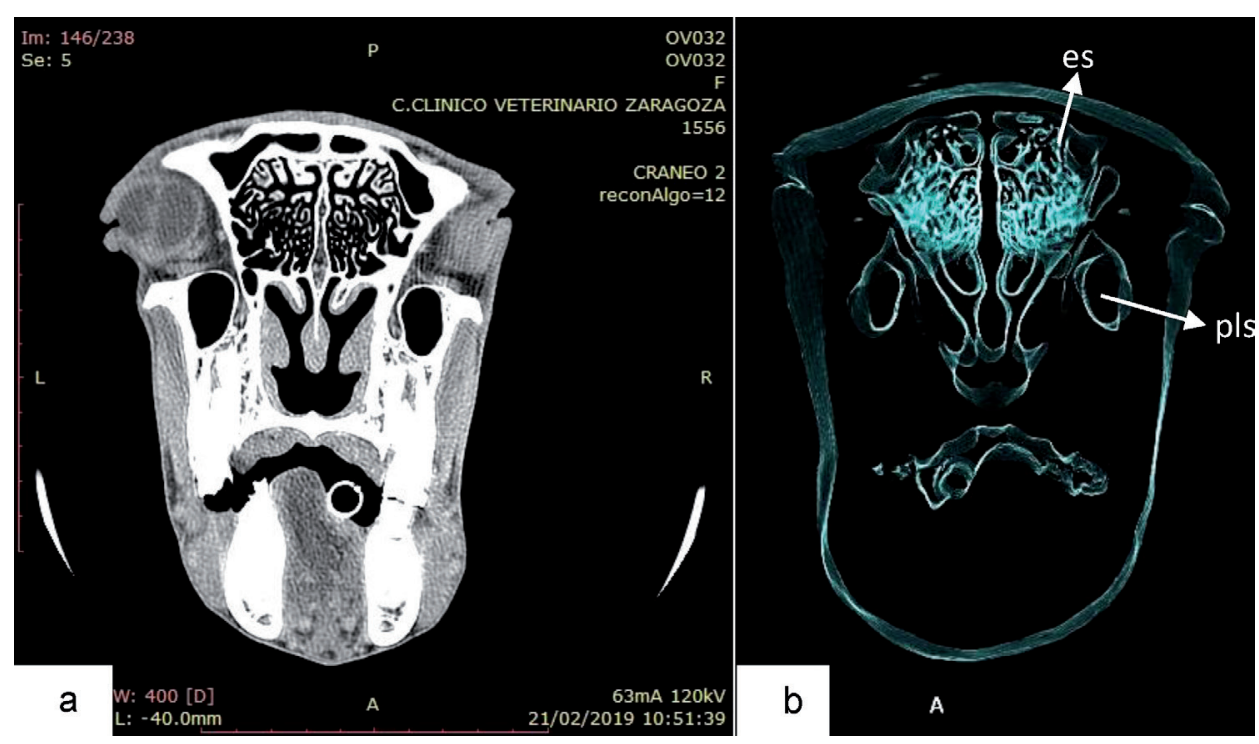

Figure 4.

Ethmoidal turbinate of a healthy ewe. (a) CT axial view of the head at ethmoidal turbinate level. (b) CT axial $3 D$ view with airways filter. View of the aerial surfaces of the ethmoidal sinuses (es) and the paranasal lacrimal sinus ( $p l s)$.
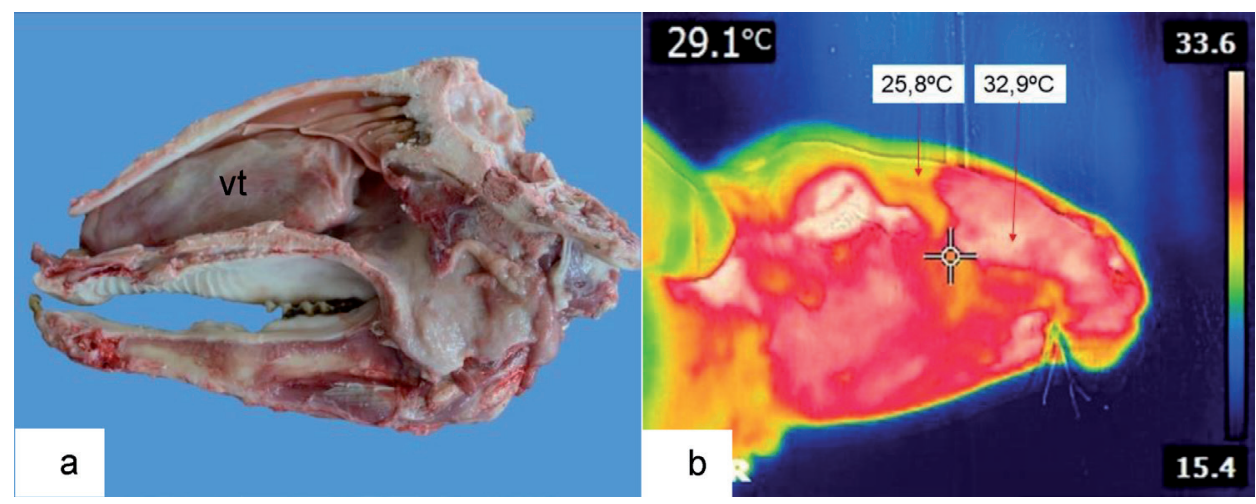

Figure 5.

Chronic proliferative rhinitis. (a) Sagittal cut of the head avoiding nasal septum. Enlarged ventral turbinate $(v t)$ is appreciated. (b) Thermography of the right size of a CPR-affected sheep with a relevant increase in temperature in the swollen area.

\subsubsection{Enzootic nasal adenocarcinoma}

Enzootic nasal adenocarcinoma (ENA) is a contagious tumor of the ethmoid turbinate mucosa caused by a betaretrovirus known as enzootic nasal tumor virus 1 (ENTV-1), which only affects sheep [9]. Goats can also be affected by an enzootic nasal adenocarcinoma which is caused by an enzootic nasal tumor virus of goats (ENTV-2) $[9,10]$. It is a contagious chronic disease of the upper airways that has been described in farms all over the world, except in New Zealand and Australia [9].

ENA prevalence in the affected flock is variable, ranging from 0.1 to $15 \%$ [9]. Preferentially, the virus affects young adults, and several cases are usually observed in the same flock. No genetic, breed, or sex predisposition has been observed [9, 11-13]. 
Use of Computed Tomography and Thermography for the Diagnosis of Respiratory Disorders... DOI: http://dx.doi.org/10.5772/intechopen.92615

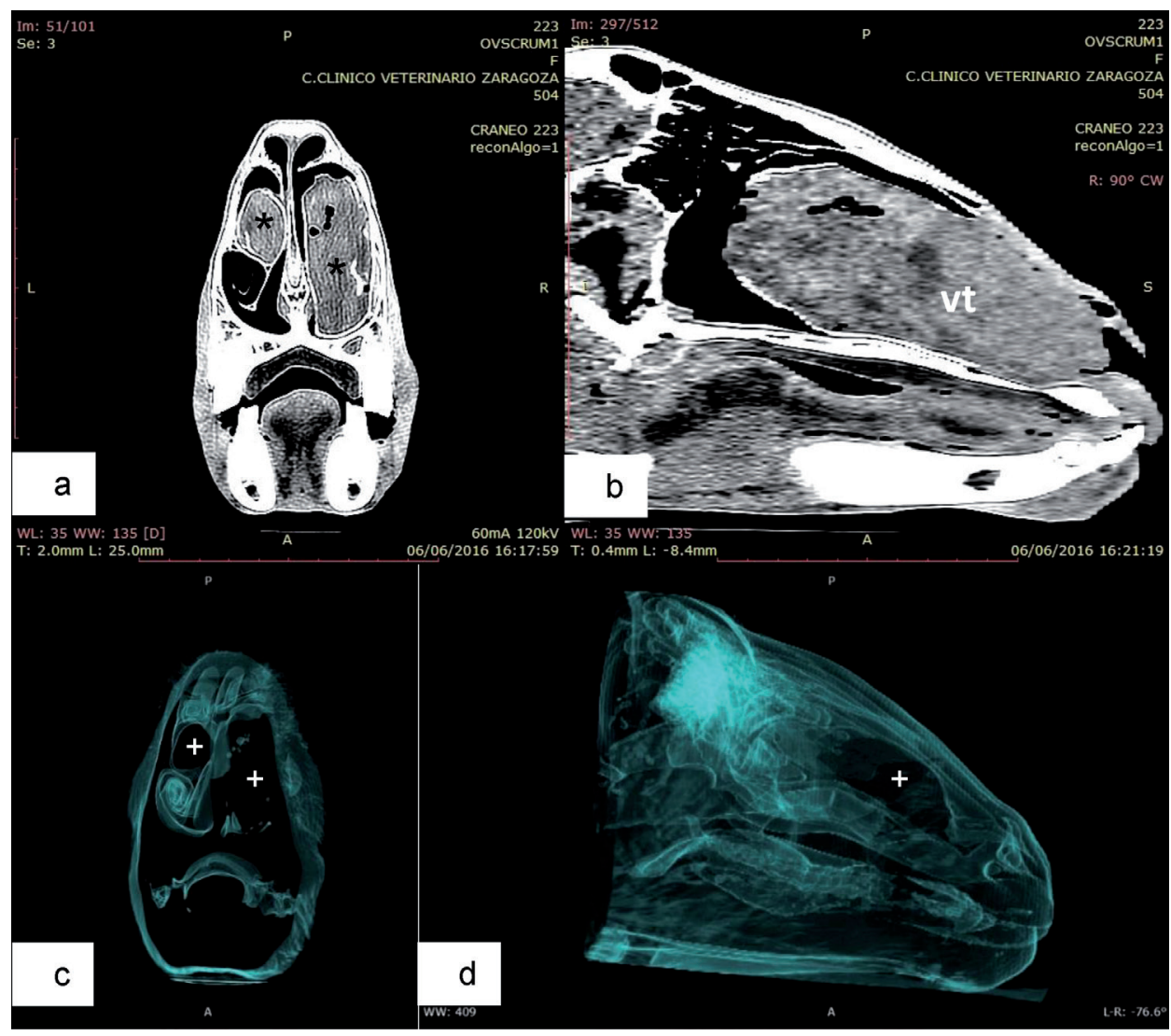

Figure 6.

Chronic proliferative rhinitis. (a) CT axial view of the head with bilateral CPR, predominantly on the right side. Gray masses $\left({ }^{*}\right)$ are the swollen turbinates. (b) CT sagittal view of the head in right nasal turbinate. Ventral turbinate (vt) increased in size is appreciated. (c) CT axial $3 D$ view with airways filter. Black spaces of the nasal cavity (+) are swollen, airless masses. (d) CT sagittal ${ }_{3} D$ view with airways filter. The large black surface (+) represents the swollen mass of CPR.

The most recognizable clinical sign of ENA is the unilateral serous nasal discharge that leads to a "washed nose" appearance, which is caused by the depilation of the area due to the continuous discharge. In advanced cases, the disease shows characteristic clinical signs such as snoring, coughing, and head shaking together with exophthalmos and softening and deformation of the skull bones (mainly frontal and maxillary) that can lead to the presentation of a skin fistula. Body condition is gradually lost, and animals eventually die due to bacterial complication of the tumor which ends with pneumonia or septicemia [9].

At necropsy, tumors are found in the nasal cavity arising from the ethmoidal mucosa and effacing the normal architecture of the ethmoidal conchae. Tumors are soft, gray, or reddish-white in color with a fine granular surface and covered with mucus (Figure 7a).

In ENA cases, the thermography shows reddish or even white colors in the posterior segment of the nose, matching the hottest areas (white color) with the ethmoidal bone, where the ENA is located (Figure 7b). The nasal cavity presents also a red color because, due to the obstruction provoked by the tumor, air cooling the area cannot pass through the nose. In the case of fistulizing and pouring liquid through the hole, the wet area can present colder tones (green, yellow) due to the evaporation of this liquid. 


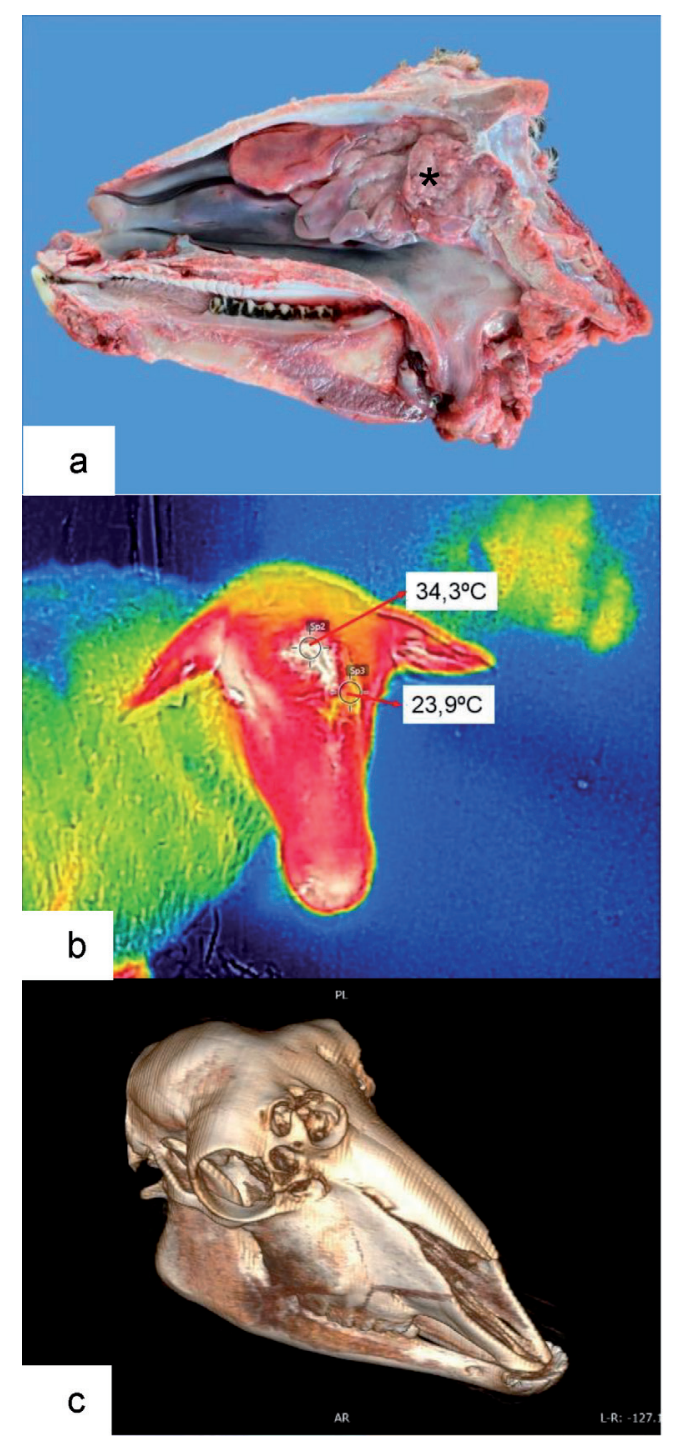

Figure 7.

Enzootic nasal adenocarcinoma (ENA). (a) Postmortem findings of ENA with polyps $\left({ }^{*}\right)$ affecting the ethmoidal turbinate. (b) Thermography. Warmer area in the right side that matches the location of the tumor. (c) $C T_{3} D$ view with soft tissue removal: skull with ENA and great bone rarefaction. The lithic process causing some holes in the nasal and lacrimal bones is shown.

The CT scan of ENA cases shows the destruction of the ethmoidal bone, the lithic curse of the nasal bone, and the soft tissues growing, sometimes with polyps in the distal part of the lesion (Figure 8), even before the nasal bone is destroyed and the face deformed (Figure 7c).

\subsubsection{Oestrosis}

Oestrosis is a worldwide cavitary myiasis caused by the larvae of the fly Oestrus ovis (Linnaeus 1761, Diptera, Oestridae) that develops from the first- to the thirdstage larvae, which are obligate parasites of the nasal and sinus cavities of sheep and goats $[14,15]$. In areas with semiarid climatic conditions, as in the Mediterranean countries, oestrosis is the most important upper respiratory tract disease from a clinical and economic point of view [16]. 


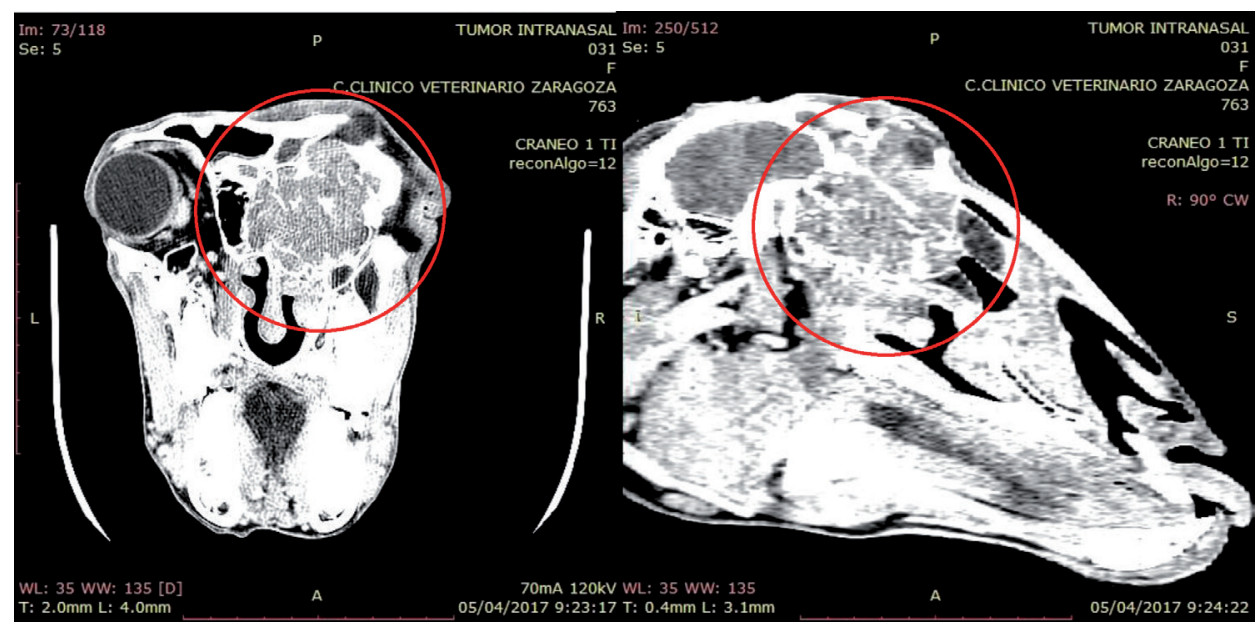

Figure 8.

Enzootic nasal adenocarcinoma. CT axial and sagittal view of an ENA in the right side of the skull (red circles).

Oestrosis is a collective disease with a high prevalence in which clinical signs have a seasonal variation, being more severe during hot and dry periods $[15,17]$. The larvae produce chronic inflammatory rhinitis, and the affected animals present mucus, purulent, or even hemorrhagic nasal discharge [16, 18, 19]. Inspiratory dyspnea, frequent sneezing, head shaking, and emaciation are clinical signs that often accompany the mucopurulent nasal discharge $[14,15]$.

For the diagnosis of this disease, thermal images are not used unless the parasitation is very severe. CT images are only useful in the final stage of the larvae (L3). Tomographic pictures show the secretions, the swollen tissues of the turbinates, and even the segments of the larvae (Figure 9a-c), but its clinical use is not justified in this disease.

\subsubsection{Intranasal abscess}

As in other body areas, bacterial abscesses can be found inside the nasal cavity, causing distress and respiratory disorders [20-22]. These abscesses can even lead to facial deformation and fistulization (Figure 10a).

In thermographic images high temperatures (red and white colors) can be observed on the affected area (Figure 10b). Although the thermal camera will only provide useful images if the abscess is attached to the surface or if bone rarefaction has occurred. Nevertheless, CT delivers valuable images of abscess location, size, and content; likewise, the damage to the different surrounding tissues and the invasion to the nearby areas can be observed (Figure 11).

\subsubsection{Sinusitis}

Generally, primary sinusitis is caused by an upper respiratory tract infection of the paranasal sinuses, and secondary sinusitis is caused by a tooth root infection [23]; however, frontal sinusitis can be caused by an upper respiratory tract infection or by the breaking of a horn or an inappropriate dehorning [24, 25].

There is a close relationship of the maxillary posterior teeth to the maxillary sinus, so a periapical dental infection or the breaking of a tooth can cause a secondary infection of this sinus [26]. Also, inflammation and swelling in the nasal mucosa 


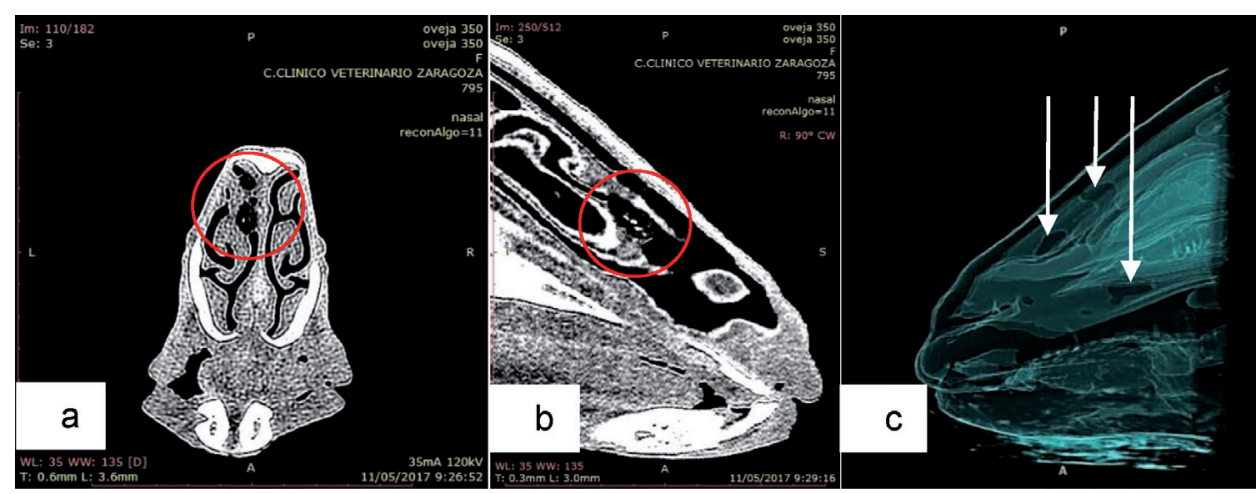

Figure 9.

Oestrosis. (a) CT axial view of a sheep head affected by oestrosis. A larva cut crosswise between the ventral and dorsal turbinate is shown. Another small larva in the dorsal turbinate and mucus in the common nasal meatus is appreciated (red circle). (b) CT sagittal view with the presence of a crosswise cut larva in the cranial area of the ventral turbinate (red circle). (c) CT 3 D view with airways filter. This technique shows the larvae-occupied areas and the mucus as black airless areas (white arrows).
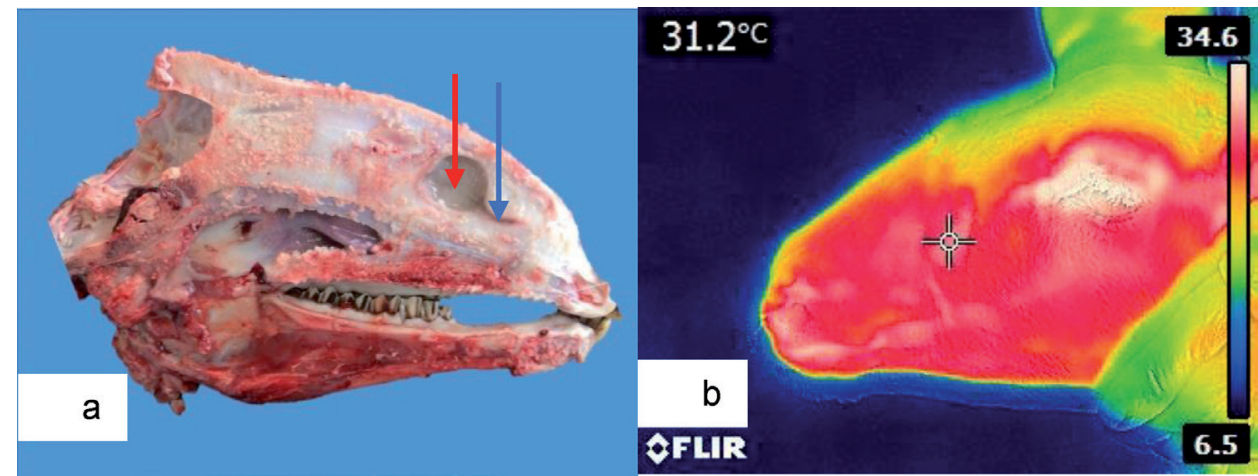

Figure 10.

Intranasal abscess. (a) Postmortem findings of a circular abscess in nasal septum (red arrow) with a fistula draining into the common nasal meatus (blue arrow) are shown. (b) Thermography. A warmer area (whiter crossed zone) is seen in the projection of the abscess than in the surrounding tissues.

from a viral or bacterial infection could obstruct the nasomaxillary opening, blocking sinus drainage and predisposing to a sinusitis [23].

In sheep, there are a huge range of possible etiologies that can cause sinusitis: mycosis, such as those produced by Conidiobolus sp., as it has been described in sheep in Brazil and Uruguay causing necrotic sinusitis [27]; or due to the action of Oestrus ovis larvae $[15,28]$; or by a wide variety of bacterial agents $[23,29]$.

The thermographic camera captures the focal heat that reaches the outside (Figure 12), since the sinuses are close to the surface of the animal's face. Using CT scan, the modification of the different structures, dental problems, or horn disorders can be studied (Figure 13).

\subsubsection{Pharynx abscesses}

The respiratory processes of the pharynx and larynx are scarcely diagnosed in sheep. Cases of pharyngeal abscess [22] or sarcocystis infestation in the larynx, causing laryngeal hemiplegia [30], have been reported but always as individual cases of very low prevalence. Further, laryngeal chondritis has been widely described in Texel and Southdown breeds in the UK and leads to breathing 
Use of Computed Tomography and Thermography for the Diagnosis of Respiratory Disorders... DOI: $h t t p: / / d x . d o i . o r g / 10.5772 /$ intechopen.92615

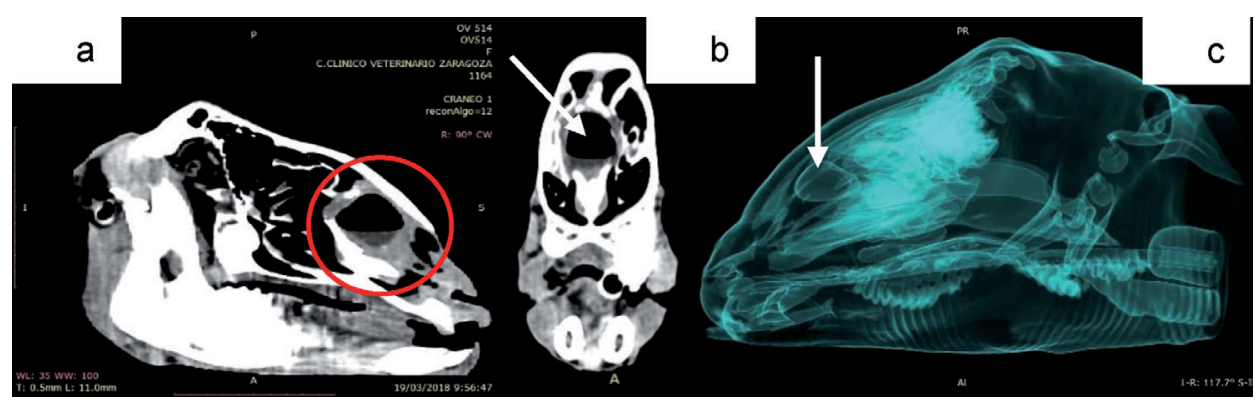

Figure 11.

Intranasal abscess. (a) CT sagittal $3 D$ view of a head with an intranasal abscess located in the nasal septum. An abscess full of air in the upper area and pus in the lower area is shown (red circle). (b) CT axial view of the same abscess (white arrow). (c) CT $3 D$ view with airways filter. This technique shows a flat-bottomed bubble generated by emptying the part of the pus from the abscess through the fistula (white arrow).

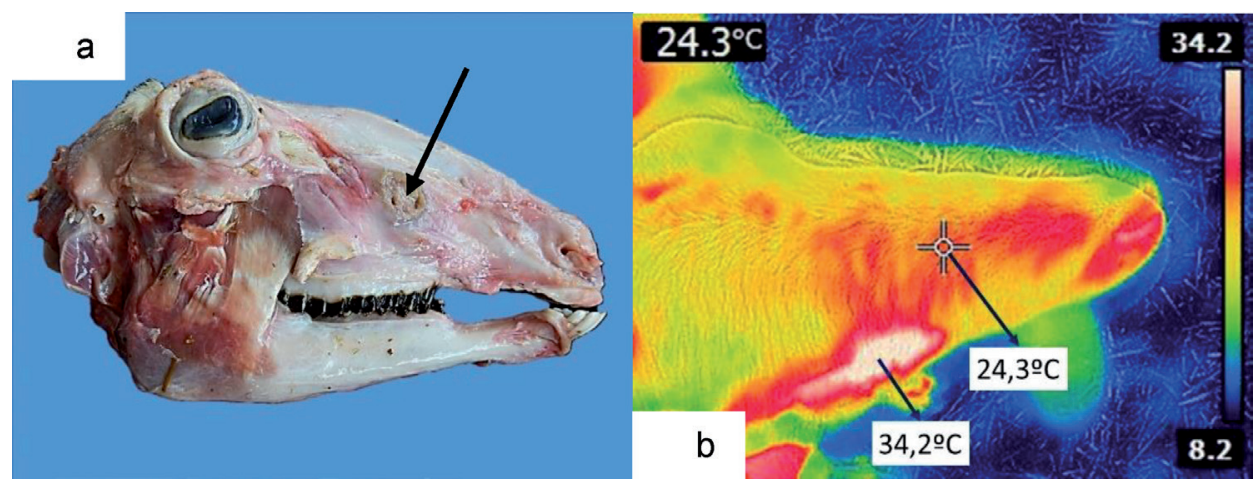

Figure 12.

Maxillary sinusitis. (a) Bone rarefaction without fistulization (black arrow). (b) Thermography. Warmer area (white) compared to a normal point in the center of the image (white cross).

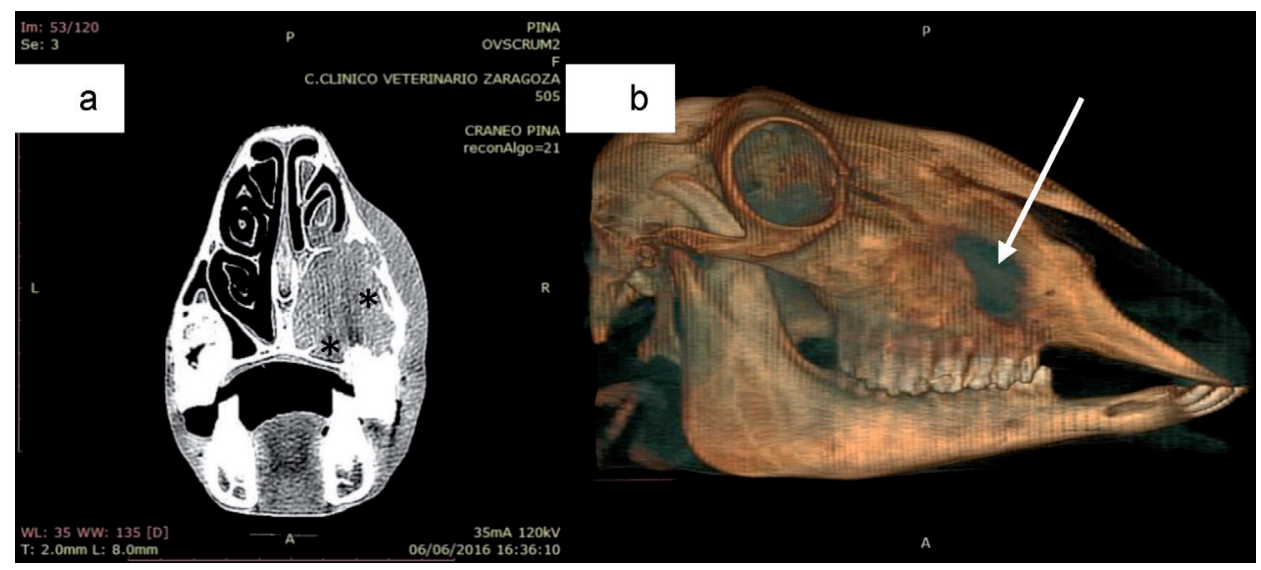

Figure 13.

Maxillary sinusitis. (a) CT axial view with purulent material accumulation in palatine and maxillary sinus $\left({ }^{*}\right)$ which causes ventral turbinate and face deformation. No tooth pathology was found. (b) CT $3 D$ view. Bone rarefaction without fistulization (white arrow).

problems, with swelling and discharges in the larynx [31], but it has never been diagnosed in Spanish breeds.

Caseous lymphadenitis (CLA) is a common disease in sheep affecting lymph nodes. If Corynebacterium pseudotuberculosis, the etiological agent, infects the 
retropharyngeal or submandibular lymph nodes, these can press the pharynx and larynx producing deformation and respiratory distress [22].

Thermographic and tomographic images will not have a fixed pattern, depending on the affected structures. CT images contribute to clarify how the abscess is and in what structure the pressure causing respiratory distress is being produced (Figure 14).

\subsection{Lower respiratory tract disorders}

The trachea is a non-collapsible and about $25 \mathrm{~cm}$ long tube formed by incomplete 48-60 cartilaginous rings in the sheep and the goat (Figure 15). In sheep, the cross-sectional outline of the trachea differs from one region to another. In the larynx region, the outline is round, but with a low dorsal crest, whereas the middle-third of the trachea is U-shaped, as in the goat.

The lungs are the respiratory organs responsible for performing several functions; the gas exchange is the most important. They are also accountable for the elimination of foreign bodies carried by air through the mucociliary clearance and alveolar macrophages, and finally, the lungs also perform metabolic and endocrine functions, activating the inactive prohormones or protecting the organism from potentially toxic vasoactive substances [32]. Each lung occupies a pleural cavity (pleural sacs), and between them lays the mediastinum, a complex area that divides

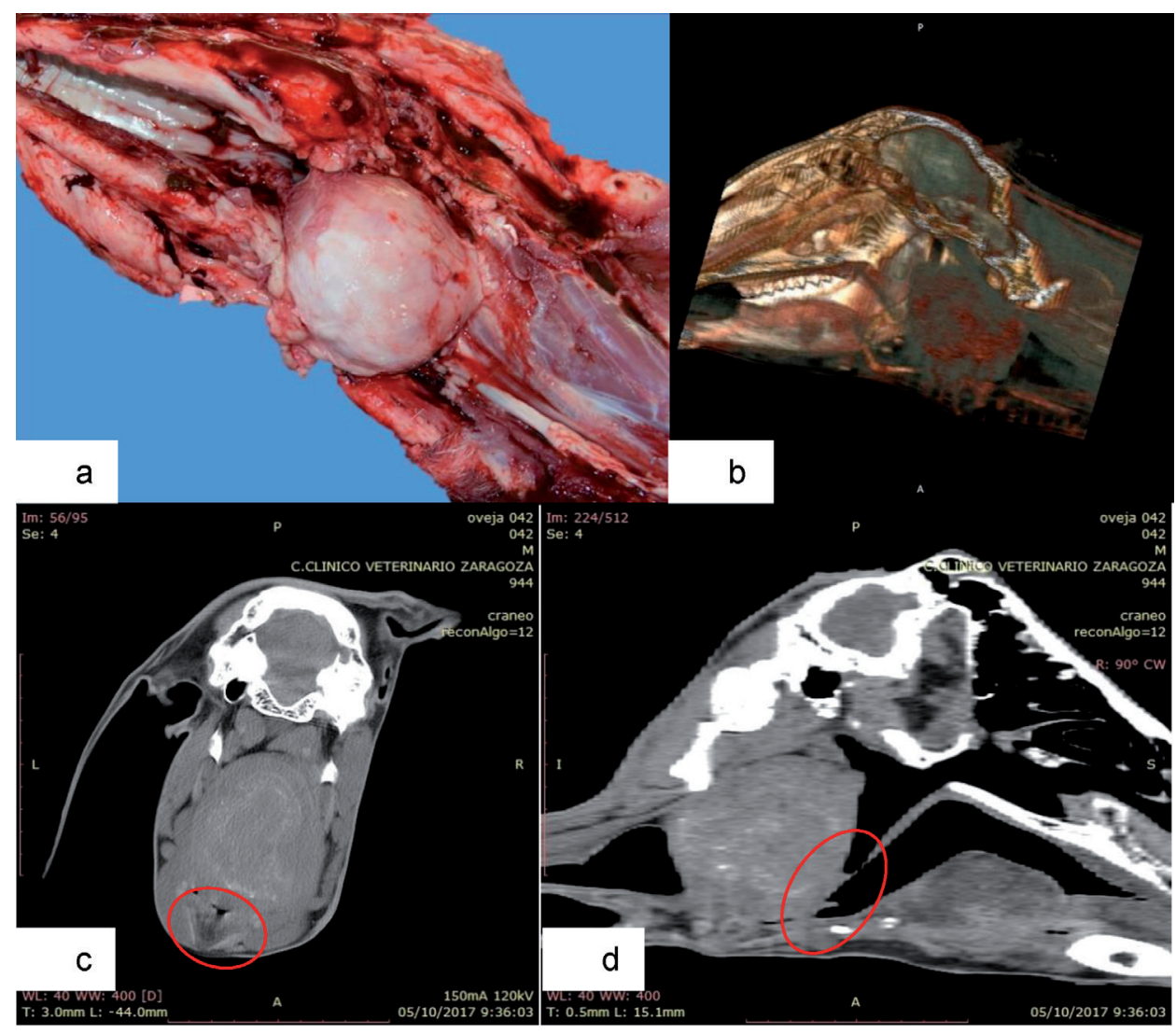

Figure 14.

Eight centimeter diameter larynx abscess caused by Corynebacterium pseudotuberculosis. (a) Postmortem findings show a large abscess in pharyngeal area. (b) CT $3 D$ view. Spatial location of the abscess in relation to pharynx and larynx. (c) CT axial view. Compression of larynx cartilage (red circle). (d) CT sagittal view. Pressure on the larynx and contact with the veil of the palate (red circle). 
Use of Computed Tomography and Thermography for the Diagnosis of Respiratory Disorders... DOI: $h t t p: / / d x . d o i . o r g / 10.5772 /$ intechopen.92615

the thorax into two symmetrical halves [33]. In sheep, respiratory diseases are the main described disorders, producing high morbidity and mortality [34].

In a healthy sheep, the lungs take the shape of a half cone, with an apex at the upper part and an oblique base applied against the diaphragm (diaphragmatic face) (Figure 16a). Their lobulation does not exactly coincide with the large appreciable fissures in the pulmonary surface and follows the division of the trachea in the lobular bronchi. Both lungs have a cranial lobe (apical) and a caudal lobe (diaphragmatic), respectively, ventilated by a cranial and caudal bronchus. In addition, the right lung has a middle lobe and an accessory lobe, ventilated each with its corresponding bronchus. The right cranial bronchus in ruminants rises directly from the trachea, and the accessory lobe is mainly attached to the middle lobe rather than to the caudal lobe as in other mammals [35]. Dorsal and ventral CT 3D images with Airways filter and dorsal and ventral view of a silicon mold of the lung are shown in Figure 16b-e.

The main lower respiratory tract disorders will be detailed here below taking into account the tomographic support in its diagnosis.

\subsubsection{Tracheal crushing}

In intensive and semi-intensive production systems, tracheal crushing (Figure 17a) is a common disorder [35]. It seems clearly influenced by age, and recent surveys associate these lesions with management patterns when feeding animals. It is supposed that the type of feeders used during the periods of confinement can result in a key point to avoid this injury [35]. Some works relate this disorder to a worsening of animal welfare [36]. In addition, it has also been observed that these animals that presented tracheal crushing had a greater predisposition to suffer lower respiratory tract diseases [37].

CT images allow assessing the lumen of the trachea and locating the injured tracheal rings, visualizing the internal surface of this airway (Figure 17b-d).

\subsubsection{Verminous pneumonia}

Verminous pneumonia is caused by the mechanical and irritant action of parasitic nematodes, belonging to the order of Strongylida. Sheep is host to several lungworm nematode species of the families Dictyocaulidae (Trichostrongyloidea)

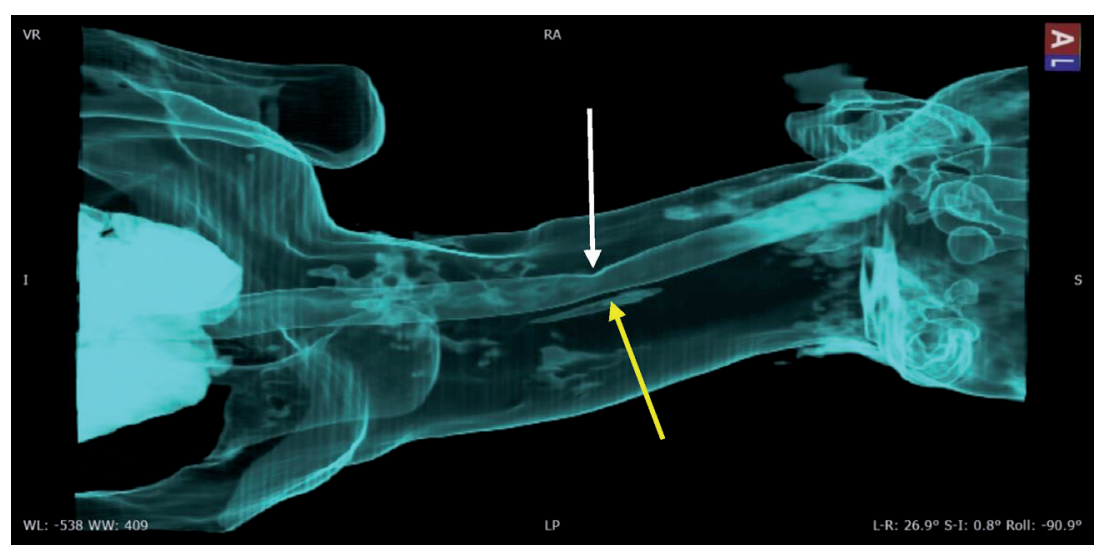

Figure 15.

$C T_{3} D$ view with airways filter. Trachea of a healthy animal with a depression caused by a tracheotomy (white arrow) performed a few hours before the CT scan and a small trace of extravasated air (yellow arrow). 


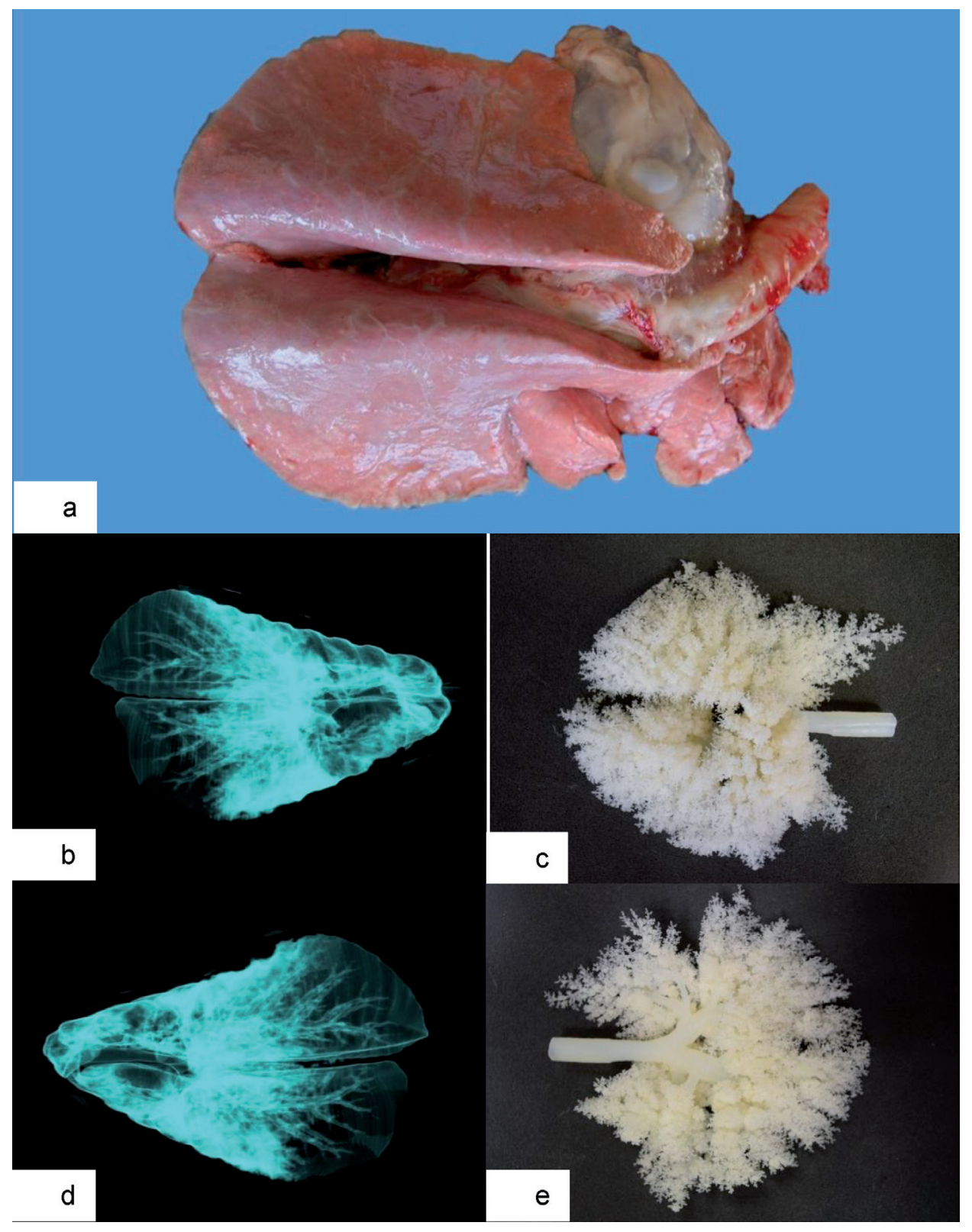

Figure 16.

(a) Healthy lung. ( $b$ and d) Dorsal and ventral CT $3 D$ images with airways filter. (c and e) Dorsal and ventral view of a silicon mold of the lung.

and Protostrongylidae (Metastrongyloidea) that induce verminous pneumonia, also called dictyocaulosis and protostrongylidosis. Dictyocaulus filaria, a thin white trichostrongylid-like nematode up to $10 \mathrm{~cm}$ long, is the largest sheep lungworm and affects caudal and diaphragmatic lung lobes. The most common protostrongylid species found in sheep are Muellerius capillaris, Protostrongylus rufescens, Protostrongylus brevispiculum, Cystocaulus ocreatus, and Neostrongylus linearis [38], which produce nodular pneumonic areas in the dorsal part of the lung.

Although, in endemic areas, lambs may show cough and unthriftiness during the first grazing season, in adults, clinical signs of pneumonia or other respiratory symptoms have rarely been observed, being pathological findings identified only 


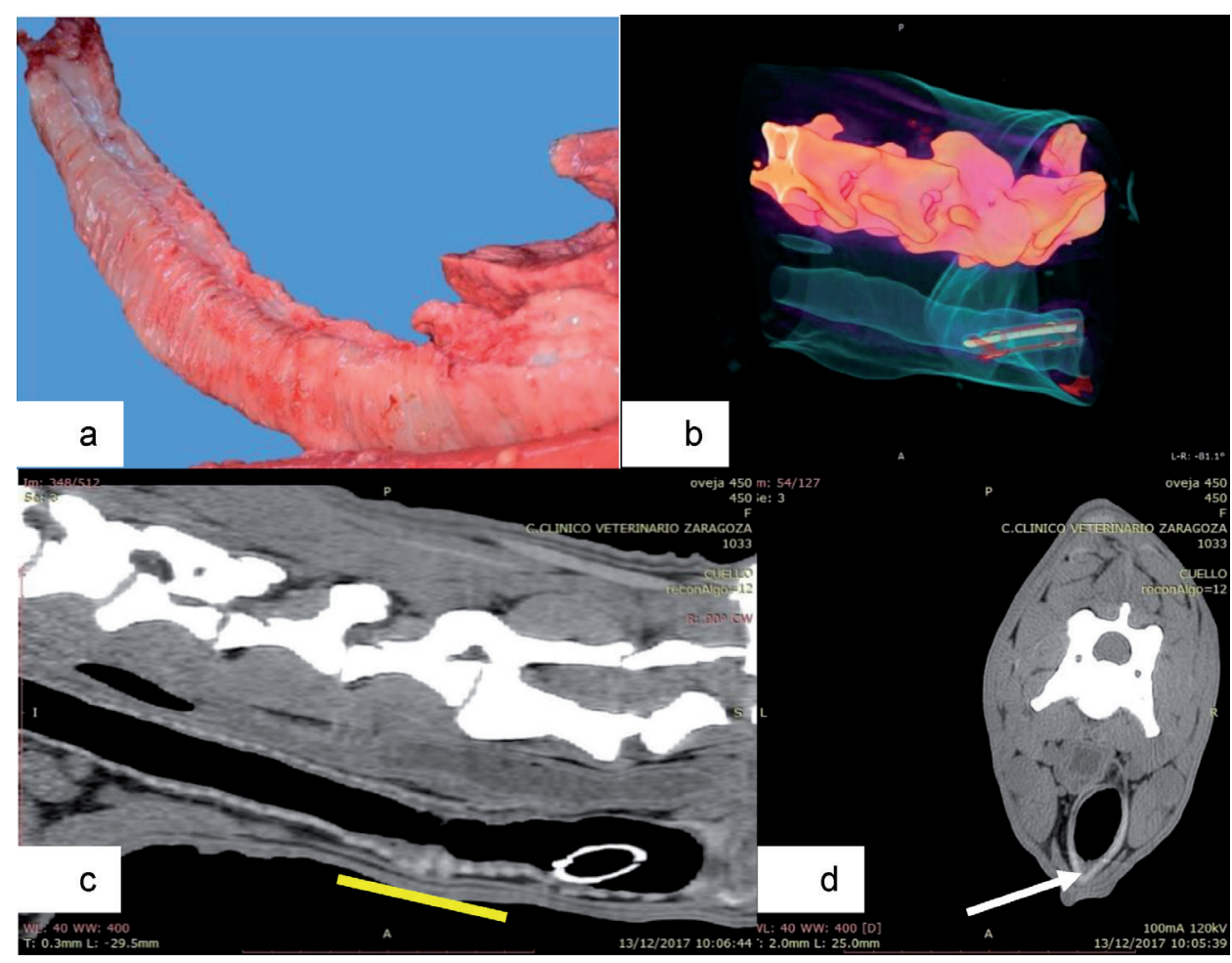

Figure 17.

Tracheal crushing. (a) Necropsy shows the trachea with different flattened rings. (b) CT $3 D$ view with bones and skin 3 filter. Tracheal lumen view with obvious deformations. (c) CT sagittal view. Severe deformation of tracheal rings (yellow line area). (d) CT axial view. Crushed tracheal ring with deformation in ventral area (white arrow).

at necropsy. Thus, two different types of subpleural nodules can be found: the verminous nodules containing a single worm that may be calcified and the breeding nodules, ranging from less than $1 \mathrm{~mm}$ to several centimeters in diameter, noncalcified, and containing mature reproducing adults and larvae. These nodules can be macroscopically observed as hard, slightly prominent, and greenish-gray due to the infiltration of eosinophils [39] (Figure 18a).

In the case of dictyocaulosis, computed tomography images show an increased thickness of the caudal and diaphragmatic areas of the lung, whereas in protostrongylidosis, nodular pneumonic areas located in the dorsal part of the lung can be observed (Figure 18b-d).

\subsubsection{Lung abscesses}

The lungs are continuously exposed to air that contains dust, bacteria, fungi, viruses, and various noxious agents $[40,41]$, favoring the development of different diseases, including abscesses. These abscesses are often caused following previous lung damage, secondary to other lung injuries, or may follow an embolic spread from another focus of infection [42].

Abscess is a necrotizing lesion characterized by a pus-filled cavity that is encapsulated by fibrous tissue [43] that can be located anywhere in the lung, such as pleura and lung parenchyma (Figure 19a), or even in regional lymph nodes, as mediastinal lymph nodes.

There are a great variety of bacteria that can cause lung abscesses, such as Corynebacterium pseudotuberculosis, Trueperella pyogenes, Staphylococcus aureus, 


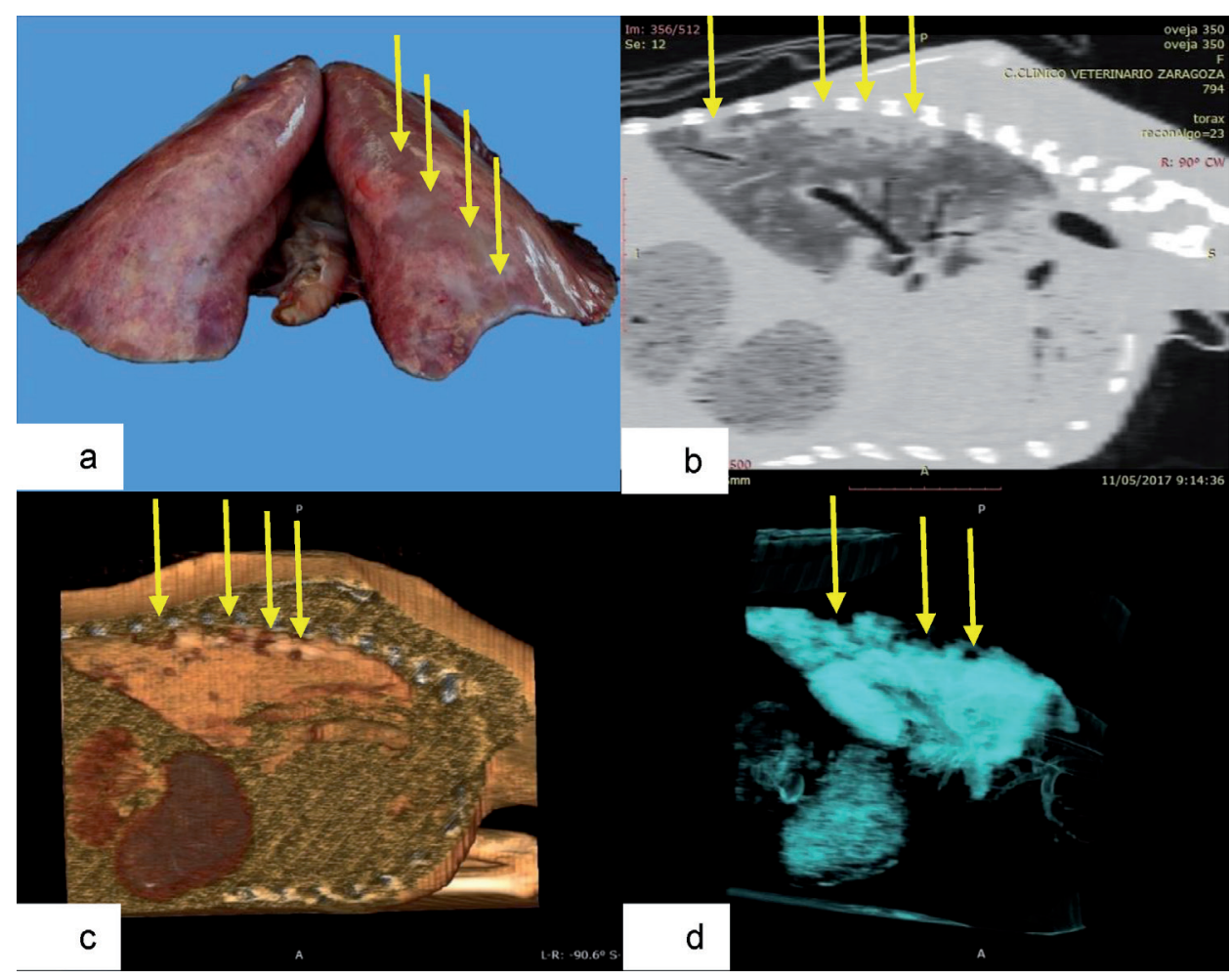

Figure 18.

Verminous pneumonia. (a) Pathological findings of a lung affected with verminous pneumonia, especially appreciated on the right side (yellow arrows). (b) CT sagittal view of the right lung with higher density whitish nodules in the dorsal area (yellow arrows). (c) CT $3 D$ sagittal view of the right lung. The gaps in the dorsal area correspond to the consolidated areas of the lung (yellow arrows). (d) CT $3 D$ sagittal view with airways filter. Black areas (yellow arrows) show the location of the nodules.

\section{Fusobacterium necrophorum, Mycobacterium tuberculosis, Streptococcus pyogenes,}

Escherichia coli, etc. [40, 44, 45].

Computed tomography provides a specific image of the abscesses, their location (Figure 19b and c), and injured tissues involved in the disease (Figure 19d) as well as non-air flow pulmonary parenchyma. Frequently, an enhanced area around the abscess and mineralization within the abscess due to caseous necrosis, especially in the case of C. pseudotuberculosis infection, can be observed.

\subsubsection{Ovine respiratory complex in adults}

As ovine respiratory complex (ORC) in lambs, in adults, ORC is a complex disease involving a range of host-pathogen-environment interactions, where host immunological and physiological mechanisms interact with multiple etiological agents including bacteria, plus environmental factors or stressors [46]. There are three clinical presentation forms of the disease: hyperacute or peracute, characterized by sudden deaths due to septicemia; acute and subacute forms, with the classical clinical signs of a pneumonic process, whose severity will vary depending on the degree of lung consolidation; and chronic pneumonia with mild or unapparent clinical signs and fibrous tissue increasing the severity of consolidation [46].

Several infectious agents have been associated with ORC: Mannheimia haemolytica, Pasteurella multocida, Bibersteinia trehalosi, and Mycoplasma sp., which usually are found mixed in the isolates with more than one bacteria species 


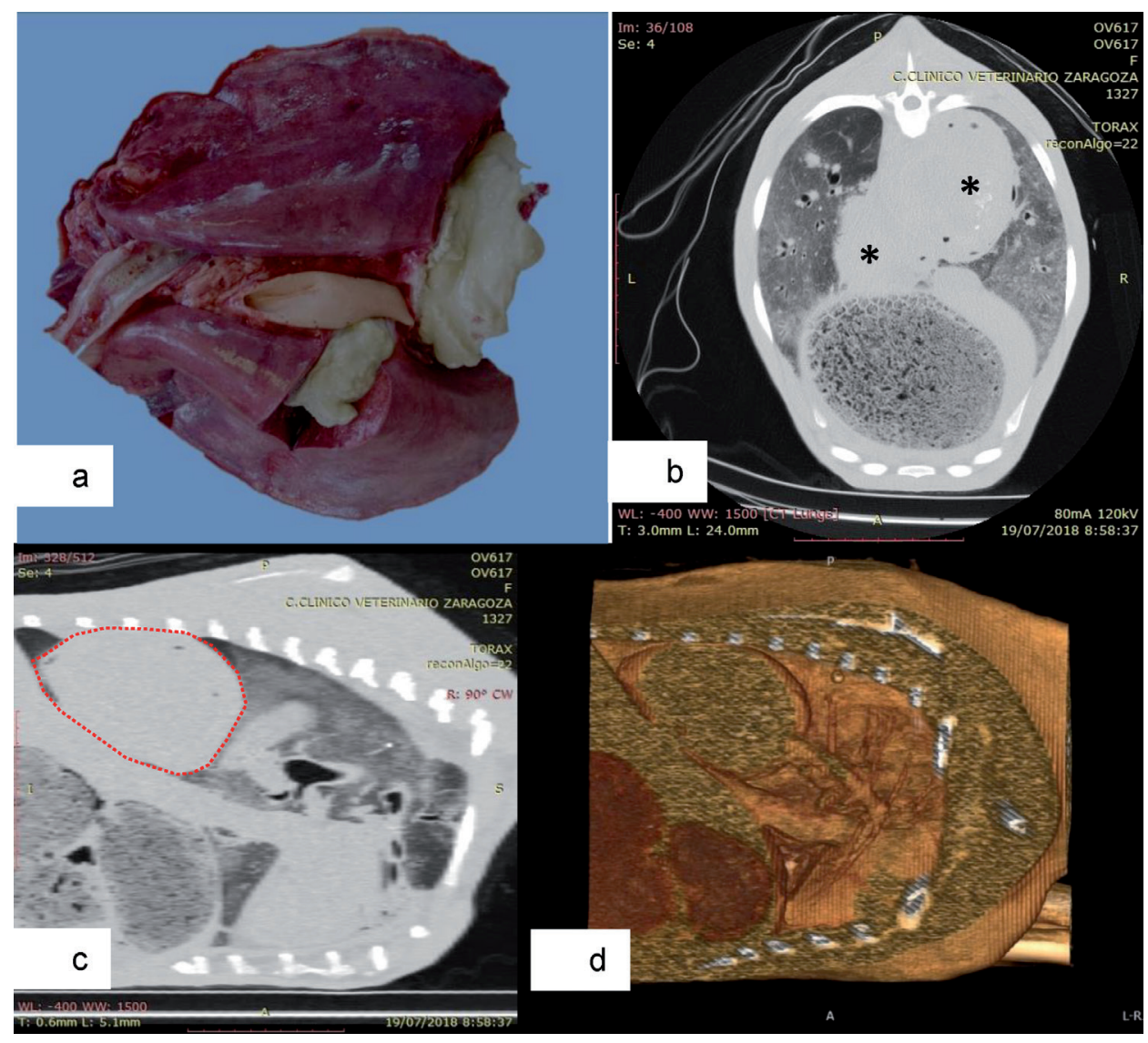

Figure 19.

Lung abscess. (a) Postmortem findings with large-size abscesses in both lungs. (b) CT axial view with whitish abscesses on both sides of the mediastinum $\left({ }^{*}\right)$. (c) CT sagittal view of the right lung with a large-size abscess in caudal lobe contacting the diaphragm (red-dashed line). (d) CT $3 D$ image where bronchial division is shown until it disappears into the abscess.

implicated [47]. Moreover, most of these bacteria exist as commensal organisms of the nasopharynx, tonsil, and lungs of healthy sheep and under certain circumstances are able to produce disease [48].

Computed tomography images reveal a good view of the injured areas. Collapsed lung areas are more opaque and whitish, while healthy tissue remains the typical gray color of a lung full of air. It is interesting to highlight that air usually remains inside the thickest bronchia even when they are surrounded by pneumonic tissue (Figure 20a and b) and that the affected tissue usually occupies the cranioventral parts of the lung (Figure 20c and d). With the computer programme associated with the CT scanner, it is possible to measure the affected area of the lung, and based on this measurement, the progression of the disease can be followed.

\subsubsection{Gangrenous pneumonia (aspiration pneumonia)}

Gangrenous pneumonia is a pulmonary infection commonly caused by inhalation of foreign materials, which produce inflammation and necrosis of the lung parenchyma. This is the reason why this pneumonia is also known as foreign body pneumonia, aspiration pneumonia, or necrotizing pneumonia $[46,49]$. The aspirated material is usually inspired into the anteroventral lobes of the lung where it produces a moderate to severe, peracute or subacute, 


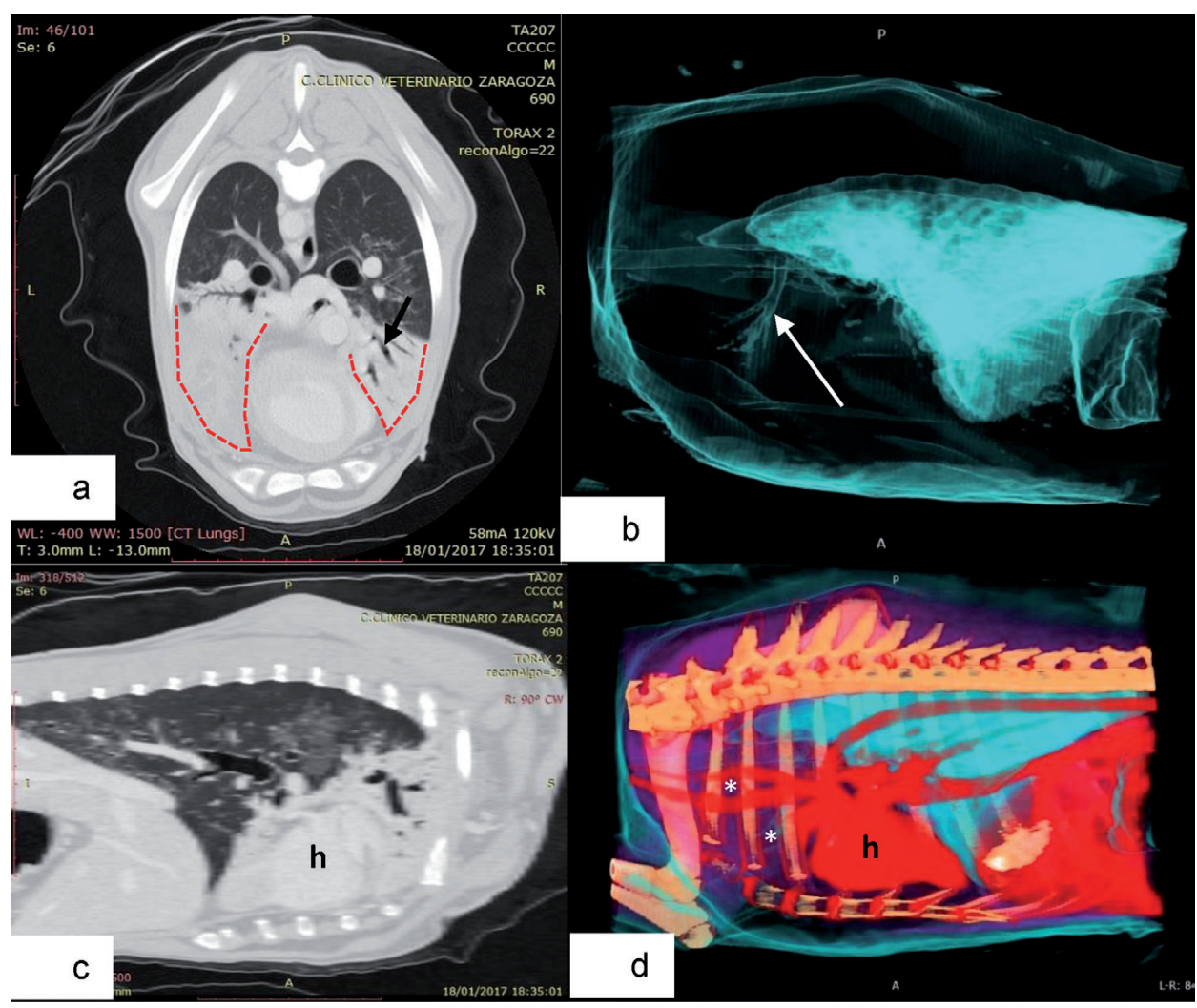

Figure 20.

Ovine respiratory complex. (a) CT axial view. Consolidation (red-dashed line) on the ventral area is appreciated, but the air remains inside the thickest bronchia (black arrow). (b) CT $3 D$ view with airways filter. It is appreciated how the air disappears in the affected lobes, but it is kept inside the main bronchi (white arrow). (c) CT sagittal view of the right lung with iodine contrast. The peripheral area next to the heart $(h)$ is affected and no air is found (white). (d) CT $3 D$ image with iodine contrast and bones and skin 3 filter. It is appreciated that the air (blue) does not reach the cranioventral thoracic area $\left(^{*}\right) .(h)$ : Heart in red with its vessels.

necrotizing bronchopneumonia, depending on the composition of the inhaled material, the microorganisms involved, and the host response [46].

Aspiration of foreign material into the lung can be due to a range of causes such as rumen content during choking or when the animal is under general anesthesia, the presence of a megaesophagus, after an inappropriately oral administration of treatments, or even as a result of another respiratory disorder that hinders breathing [20, 46, 49-52].

Foreign bodies carry environmental bacteria that, when they reach the lungs, produce pulmonary necrosis foci with an accumulation of a foul-smelling exudate that sometimes could also be present in the main bronchus and trachea (Figure 21a), which generates a bad smell of exhaled air that is a clear clinical sign of these diseases [46].

Computed tomography images show necrotic tissue (dark or black) with diffused edges. In the injured area, necrotic content caves are present (Figure 21b and c), which can reach a large size, disappearing the lung structure as the size of the necrotic areas progresses (Figure 21d).

\subsubsection{Pulmonary lentivirus infection}

Pulmonary affection is the most severe and widespread disease form caused by small ruminant lentiviruses (SRLV) in sheep. Although lentiviral infection can 


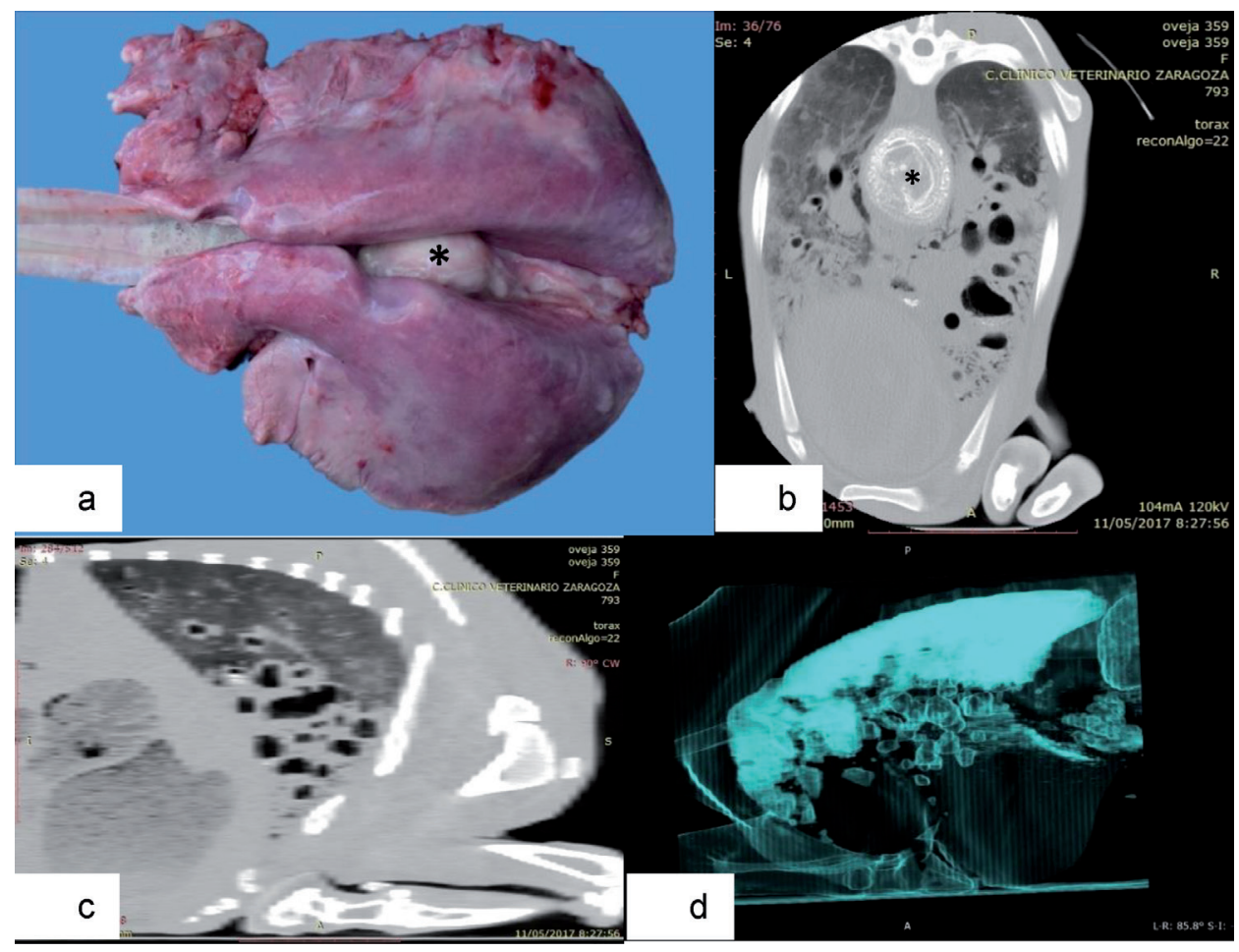

Figure 21.

Gangrenous pneumonia. (a) Pathological findings of a necrotizing bronchopneumonia and enlargement of the mediastinal lymph node $\left(^{*}\right)$. (b) CT axial view. Caverns full of air and purulent or necrotic material, more abundant on the right lung, and typical concentric layers of caseous lymphadenitis in the mediastinal lymph node $\left({ }^{*}\right)$. (c) CT sagittal view of the right lung where the big caverns are shown. (d) CT $3 D$ view with airways filter. Air in the dorsal area and inside the multiple caverns is appreciated, with no air in the consolidated ventral area.

produce different clinical presentations in sheep and goats, in this article, only pulmonary lentivirus infection will be discussed.

This disease, formerly referred to as Maedi-Visna disease, is widespread in most of the countries in the world $[53,54]$ and generally affects adult animals. The respiratory form appears in an insidious and prolonged way, and animals show dyspnea, an increased respiratory rate, weakness, and loss of weight. If the case is uncomplicated, no cough, nasal discharge, or fever is observed. Pathological findings show an increased-size lung, both in volume and weight, and a general grayish discoloration with a myriad of gray dots in the pleural surface (Figure 22a). Mediastinal lymph nodes are increased in size, surpassing the limit of the diaphragmatic lobes [55].

The widespread interstitial pneumonia caused by Maedi-Visna virus (VMV) creates enormous in vivo diagnostic difficulties due to the absence of clear clinical signs and the only presence of diffuse dyspnea that can be very confusing. For this reason, imaging techniques will be very useful tools for diagnosing this disease.

Computed tomography scanner provides a detailed image of the lesion, highlighting the increased opacity in all the parenchyma associated with the interstitial pneumonia caused by VMV (Figure 22b and c). The Airways filter allows us to see a lung with little amount of air in a generalized way (Figure 22d).

\subsubsection{Other interstitial pneumonias}

Pulmonary lentivirus infection is the disease generally associated with chronic, progressive, and diffuse interstitial pneumonia, as it is confirmed by most of 


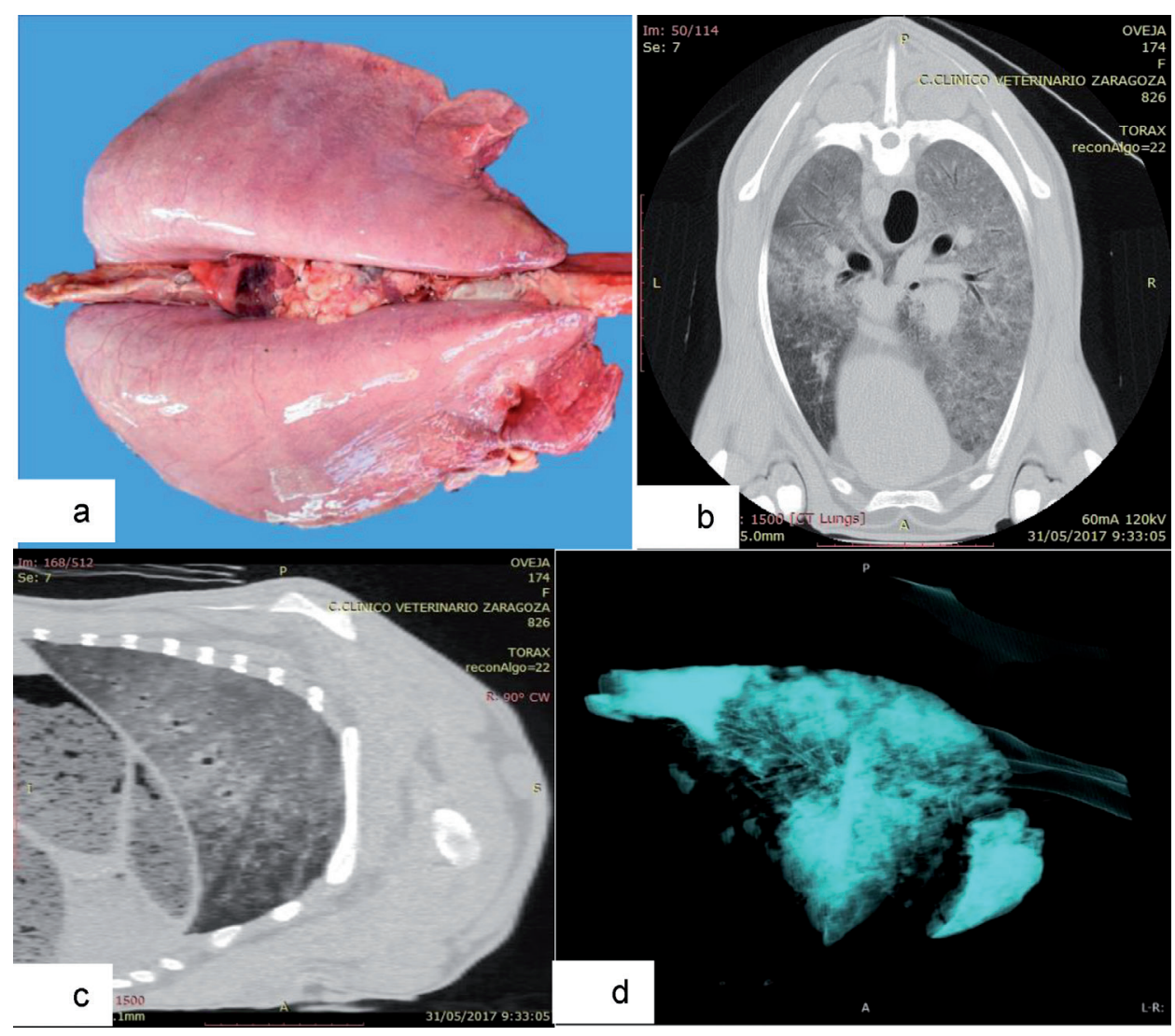

Figure 22.

Pulmonary lentivirus infection. (a) Increased-size lung with a general grayish discoloration and a myriad of gray dots in pleural surface. (b) CT axial view. Homogeneous light gray pulmonary parenchyma. (c) CT sagittal view of the right lung with the same homogeneous light gray parenchyma. (d) $C T_{3} D$ view with airways filter. Less air is seen throughout the lung, except in the cranial and caudal area.

the cases found in our daily clinical work; however, there are other interstitial pneumonias affecting adult sheep, such as those caused by Mycoplasma sp.

Although sometimes it is not possible to distinguish these two types of interstitial pneumonia macroscopically, the CT scan let us detect some cases that were not of a diffuse type but had a zonal pattern.

The clinical case presented in this section is of a zonal pattern, and, once the histopathology and microbiology was carried out, it was associated with the presence of Mycoplasma ovipneumoniae. Externally, the lung presented an interstitial pneumonia with a bicolor pattern, with some areas more reddened than others (Figure 23a).

CT scan showed lighter areas in its axial and sagittal section, located mainly in the ventral zone, and darker areas in the dorsal zone, with an intermediate area of combination of both (Figure 23b and c). CT 3D view with Airways filter showed an almost total lack of air in the dorsal area of the lung (Figure 23d).

\subsubsection{Ovine pulmonary adenocarcinoma}

Ovine pulmonary adenocarcinoma (OPA) is a contagious lung neoplasm of sheep caused by Jaagsiekte sheep retrovirus (JRSV). This disease has been reported in many of the sheep-rearing countries worldwide, being an important economic problem in the affected regions [56-58]. 
Use of Computed Tomography and Thermography for the Diagnosis of Respiratory Disorders... DOI: http://dx.doi.org/10.5772/intechopen.92615

JSRV induces neoplastic transformation of alveolar and bronchiolar secretory epithelial cells of the distal respiratory tract, developing a tumor that can grow to occupy a significant portion of the lung [58-60].

OPA is considered as an "iceberg disease" because in OPA endemic-affected herds, the majority of animals of the flock are infected (up to $80 \%$ ), but only a minority develops tumors during its productive life $[58,61,62]$. There are two pathologic forms of OPA currently recognized: classical and atypical [59].

The affected animals initially show less activity and delay in walking of the flock, followed by progressive respiratory distress, with an evidence of dyspnea and moist respiratory sounds, such as crackles and snoring, caused by the accumulation of fluid in the respiratory airways, which worsen with the increasing size of the lesions. In the final stages of the disease, variable amounts of frothy seromucous fluid are discharged from the nostrils when the sheep head is lowered [58, 59, 63]. At necropsy, neoplastic lesions are diffuse or nodular and gray or purple in color and have an increased consistency [58] (Figure 24a).

Computed tomography scan delivers a clear image of the primary tumor and of the satellite nodules that are generated in the metastasis phase (Figure $24 \mathbf{b}$ and $\mathbf{c}$ ). Serial scanners over time allow obtaining information on the evolution of the tumor or the possible regression after its experimental treatment.

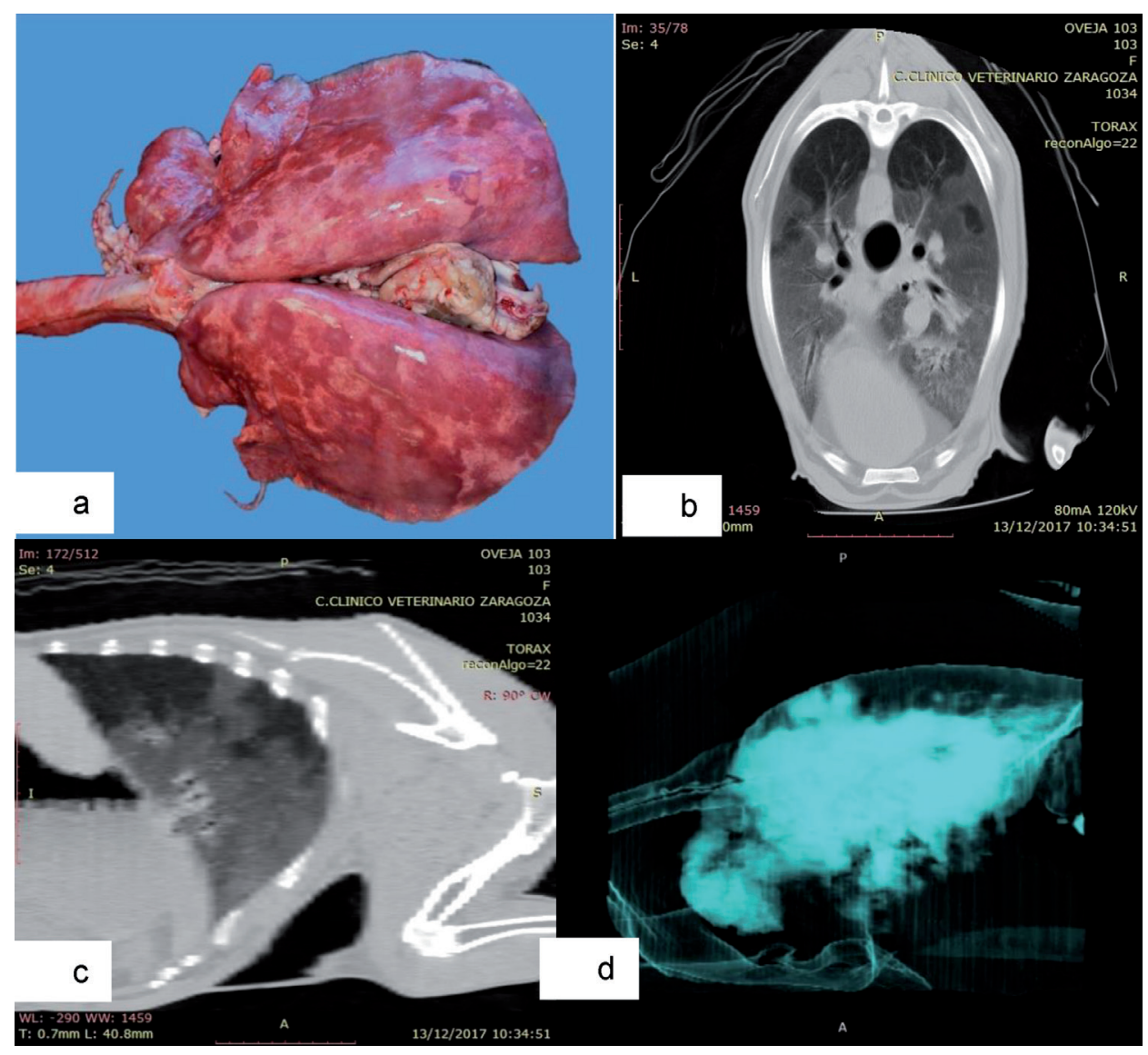

Figure 23.

Interstitial pneumonia associated with Mycoplasma sp. (a) Increased-size bicolor nonhomogeneous lung. (b) CT axial view. Homogeneous light gray pulmonary parenchyma in the ventral area and darker in the dorsal area are observed. (c) CT sagittal view with a similar pattern to that shown in (b). (d) CT $3 D$ view with airways filter. The completely lack of air in the dorsal area is shown. 
The 3D view with Airways filter shows a total absence of air in the tumor mass and, dorsally, foci of different sizes (metastasis) also without air. These lesions are usually seen surrounded by a halo with more air than normal (Figure 24d).

\subsubsection{Pulmonary atelectasis by compression}

Lung atelectasis can occur due to compression of lung tissue, absorption of alveolar air, or impaired pulmonary surfactant production or function [64]. Atelectasis by compression is what interests us from the point of view of imaging diagnosis, because with this technology, we can diagnose the cause of compression and the place where the pressures occur.

Compression atelectasis is secondary to increased pressure exerted on the lung causing the alveoli to collapse [64], and some disorders that can cause this compression atelectasis are tumors, such as mediastinal lymphosarcomas as described in horses [65] or mediastinal thymoma as described in goats [66]. The case here presented in Figure 25 is a large thymoma diagnosed in an adult ewe (Figure 25a). CT views show how the heart was displaced by the tumor to the back right side and atelectatic areas with less air near the dorsal costal wall (Figure 25b-d).

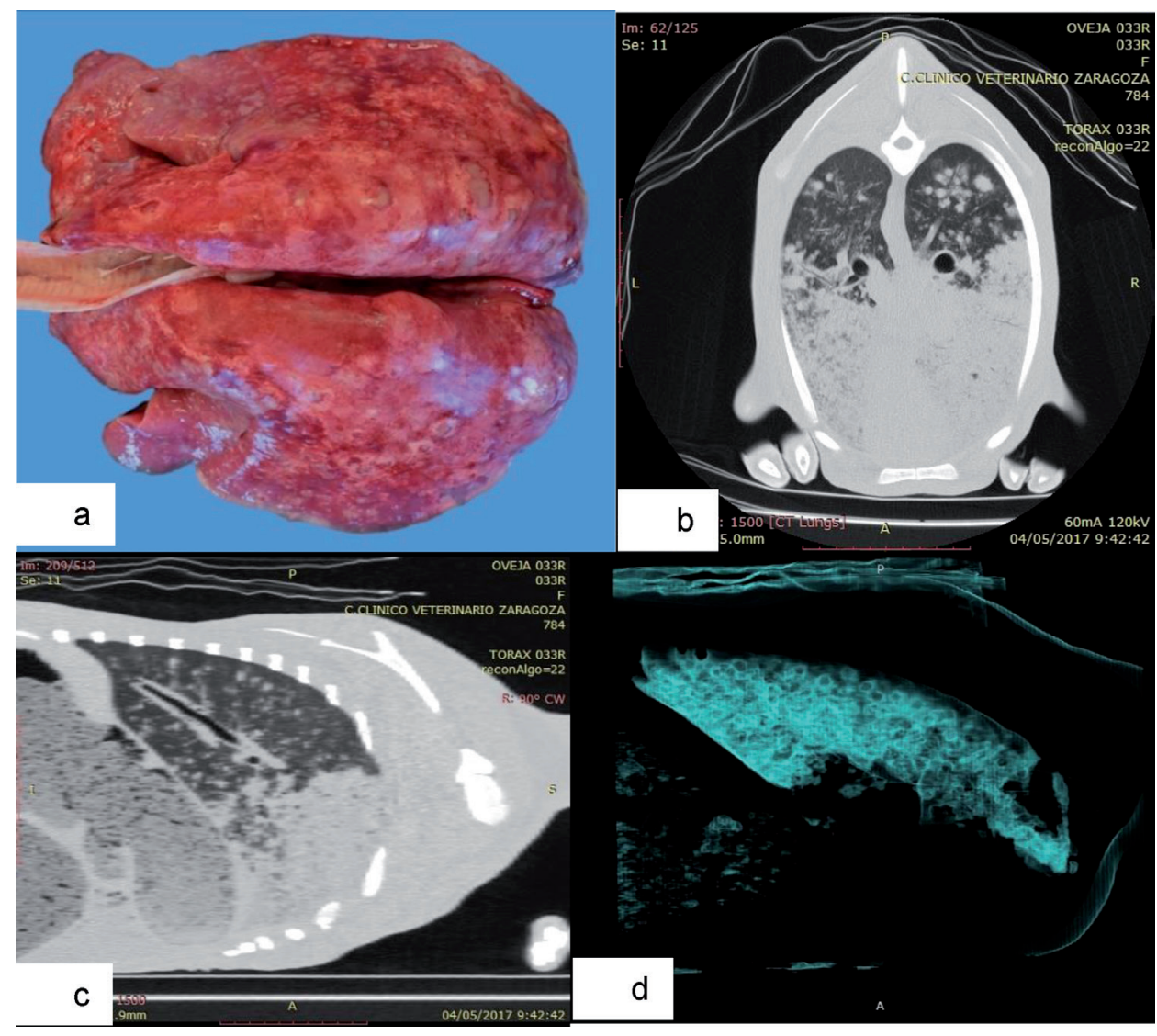

Figure 24.

Ovine pulmonary adenocarcinoma. (a) Grayish cranioventral areas and satellite nodules of the tumor. (b) CT axial view. Grayish pulmonary parenchyma with white spots (metastasis) in the dorsal area and homogeneous clear white in the ventral area (main tumor) are shown. (c) CT sagittal view of the same lung with the same pattern as (b). (d) CT $3 D$ view with airways filter. Air is appreciated in the back-caudal area, decreasing towards cranial and disappearing into the cranioventral area where main tumor mass is located. Multiple air rings can be seen surrounding the foci of metastasis. 


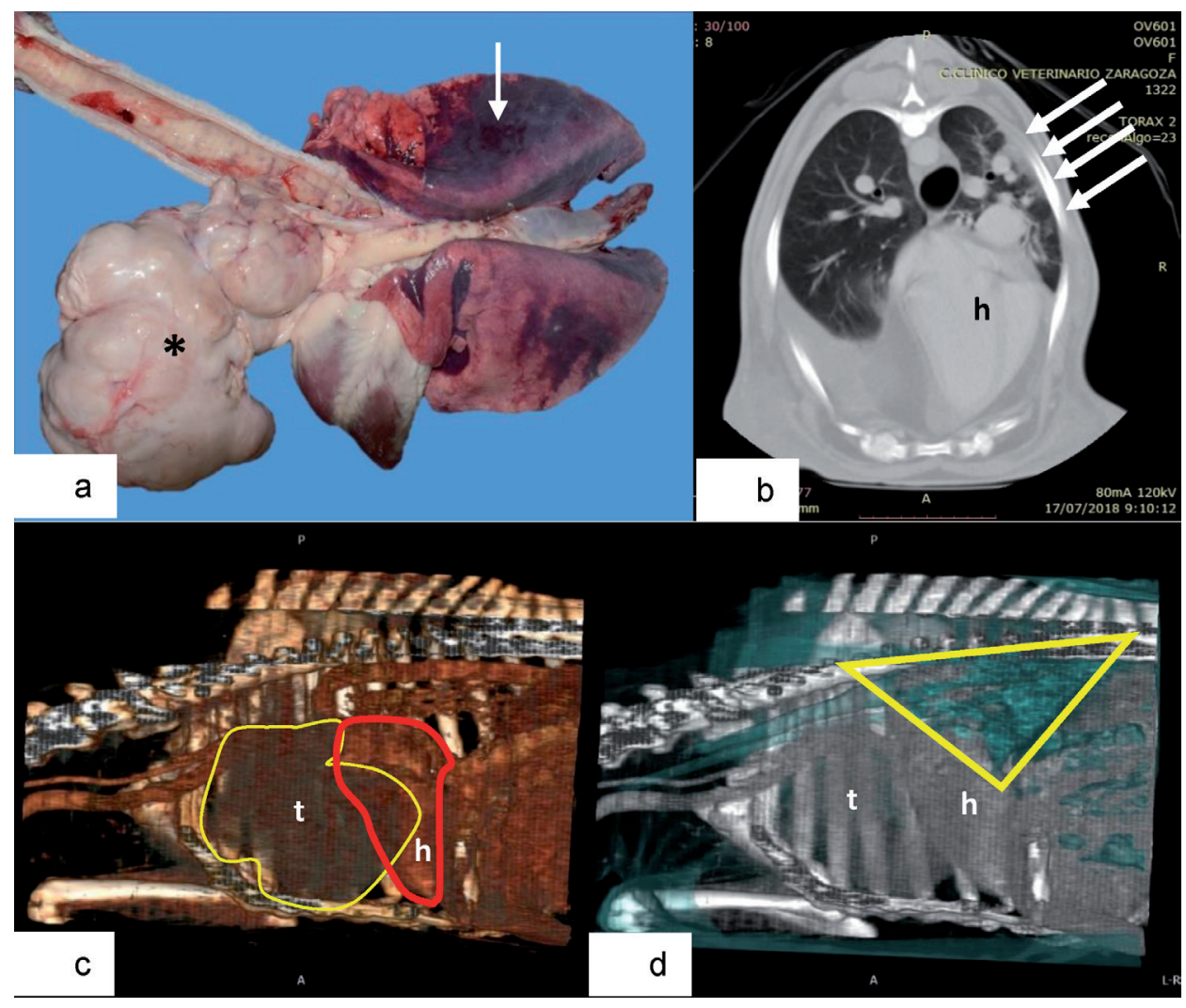

Figure 25.

Compression atelectasis. (a) Large-size thymoma $\left({ }^{*}\right)$ causing lung atelectasis, especially in the right side (white arrow). (b) CT axial view. The heart has been displaced by the tumor to the back right side ( $h$ ). Near the costal wall, atelectatic areas with less air can be seen (white arrows). (c) CT $3 D$ sagittal view, right side. Thymoma ( $t$ and yellow line) and heart ( $h$ and red line) are shown. (d) CT $3 D$ view with bones and skin 2 filter. Air is appreciated in the back-caudal area, behind the heart (yellow triangle).

Likewise, abscesses or pyogranulomas located in mediastinal lymph nodes or thoracic cavity, such as those of caseous lymphadenitis (CLA) caused by Corynebacterium pseudotuberculosis, can produce severe compression atelectasis (Figure 26a and $\mathbf{b}$ ). The visceral form of CLA commonly causes lesions in the mediastinal lymph nodes and lung parenchyma, producing severe respiratory clinical signs [67]. In a study carried out in our service on 123 culled sheep, $32 \%$ of the animals had CLA lesions, of which $70 \%$ had the visceral form of the disease, with $80.9 \%$ having lesions in the thoracic cavity [46]. In Figure 26c and d, CT 3D views show the location and size of the affected lymph nodes and a small area of atelectasis without air. Lastly, compression atelectasis can be also caused by pleural abscesses, diaphragmatic hernias, megaesophagus, or even prolonged decubitus [51, 68].

CT scan is a very suitable tool to find the cause, the situation, and the size of compression; however, it is difficult to visualize the thin layer of atelectatic tissue that can be produced next to the pressing mass or in the projection on the rib area.

\section{Conclusions}

The health of a flock is based on a proper diagnosis of the main disorders that affect the farm. Imaging tools have improved the diagnostic process and are essential today. 


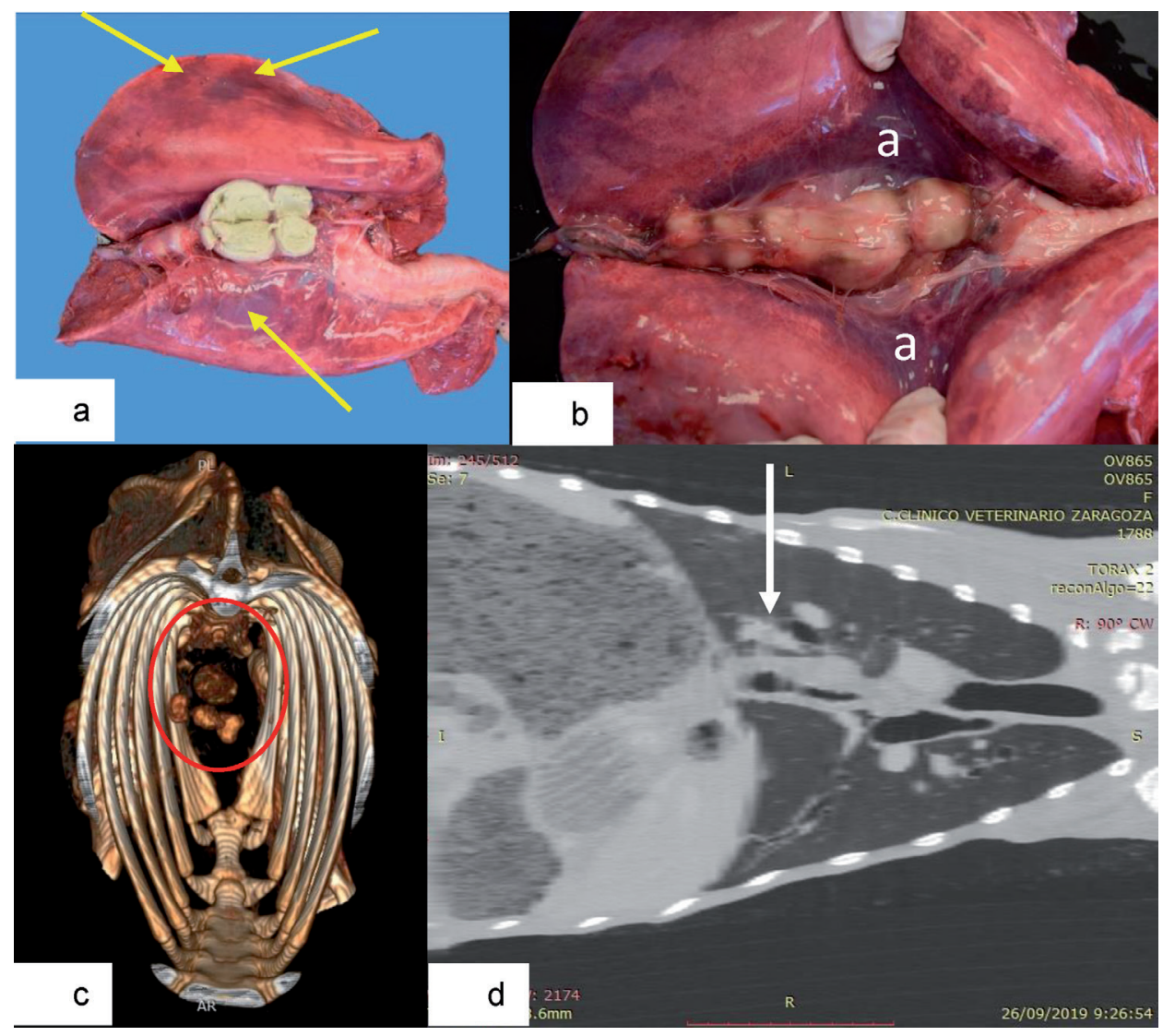

Figure 26.

Compression atelectasis. (a) Caseous lymphadenitis affecting mediastinal lymph node causing lung atelectasis in mediastinal and costal side (yellow arrows). (b) Lung atelectasis (a) in contact area with affected lymph nodes. (c) CT $3 D$ view where the location and size of the affected lymph nodes can be seen (red circle). (d) CT coronal view, where it highlighted (white arrow) a small area of atelectasis without air.

Thermography has become a useful and inexpensive tool for approaching the diagnosis of upper respiratory tract diseases. However, the use of computed tomography is more expensive and specific, reserving for the detection of important herd problems that justify its expense. It is also necessary in the investigation and monitoring of processes or treatments that have not been proven. This tool helps in an interesting way to understand the pathogenesis and lesional location since we can study the different structures and the interrelation between them in the original position.

The diagnosis of respiratory disorders in ruminants has evolved significantly thanks to the application of different imaging diagnostic techniques, detecting some diseases that until recently were little known.

\section{Acknowledgements}

We would like to thank the collaboration of veterinarians and farmers who send their interesting clinical cases to the Ruminant Clinical Service of the Veterinary Hospital (SCRUM). In addition, we would like to acknowledge the use of Servicio General de Apoyo a la Investigación-SAI, Universidad de Zaragoza.

This study was supported by the Aragón Government and the European Social Fund (Construyendo Aragón 2016-2020). 
Use of Computed Tomography and Thermography for the Diagnosis of Respiratory Disorders... DOI: http://dx.doi.org/10.5772/intechopen.92615

\section{Conflict of interest}

The authors have nothing to disclose.

\section{Author details}

Luis Miguel Ferrer ${ }^{1 *}$, Juan José Ramos ${ }^{1}$, Enrique Castells ${ }^{2}$, Héctor Ruíz ${ }^{1}$, María Climent ${ }^{1}$ and Delia Lacasta ${ }^{1}$

1 Animal Pathology Department, Instituto Agroalimentario de Aragón-IA2

(Universidad de Zaragoza-CITA), Veterinary Faculty of Zaragoza, Zaragoza, Spain

2 Centro Clínico Veterinario, Zaragoza, Spain

*Address all correspondence to: 1mferrer@unizar.es

\section{IntechOpen}

(C) 2020 The Author(s). Licensee IntechOpen. This chapter is distributed under the terms of the Creative Commons Attribution License (http://creativecommons.org/licenses/ by/3.0), which permits unrestricted use, distribution, and reproduction in any medium, provided the original work is properly cited. (cc) BY 


\section{References}

[1] Frandson RD, Wilke WL, Fails AD. Anatomy and Physiology of Farm Animals. 7th ed. Nueva Jersey, Estados Unidos: Wiley-Blackwell; 2009. ISBN-13: 978-0-8138-1394-3

[2] Redaelli V, Caglio S. Thermal imaging theory. In: Luzi F, Mitchell M, Costa LN, Redaelli V, editors. Thermography: Current Status and Advances in Livestock Animals and in Veterinary. Brescia, Italy: Fondazione Iniziative Zooprofilattiche e Zootechniche; 2013. pp. 41-46. ISBN: 978-8-8975-6206-1

[3] Meehan JT, Brogden KA, Courtney C, Cutlip RC, Lehmkuhl HD. Chronic proliferative rhinitis associated with Salmonella arizonae in sheep. Veterinary Pathology. 1992;29:556-559. DOI: 10.1177\%2F030098589202900616

[4] Lacasta D, Ferrer LM, Ramos JJ, Bueso JP, Borobia M, de Arcaute MR, et al. Chronic proliferative rhinitis associated with Salmonella enterica subspecies diarizonae serovar 61: $\mathrm{k}$ : $1,5,(7)$ in sheep in Spain. Journal of Comparative Pathology. 2012;147:406409. DOI: 10.1016/j.jcpa.2012.03.004

[5] Rubira I, Figueras L, De las Heras M, Bueso JP, Castells E, Climent M, et al. Chronic proliferative rhinitis in sheep: An update. Small Ruminant Research. 2019;179:21-25. DOI: 10.1016/j. smallrumres.2019.09.001

[6] Wolf C, Schefers J. Challenges posed by a flock problem of Salmonella diarizonae induced proliferative rhinitis. In: Proceedings of the 9th International Sheep Veterinary Congress; 22-26 May 2017; Harrogate, United Kingdom

[7] Stokar-Regenscheit N, Overesch G, Giezendanner R, Roos S, Gurtner C. Salmonella enterica subsp. diarizonae serotype 61:k:1,5,(7) associated with chronic proliferative rhinitis and high nasal colonization rates in a flock of Texel sheep in Switzerland. Preventive
Veterinary Medicine. 2017;145:78-82. DOI: 10.1016/j.prevetmed.2017.07.003

[8] López-Tamayo S, Rubira I, De las Heras M, Castells E, Lacasta D. Use of thermography for the diagnosis of chronic proliferative rhinitis in sheep and its application in the differential diagnosis of the first case affecting the dorsal turbinate. Veterinary Record Case Report. 2020;8:e001070. DOI: 10.1136/ vetreccr-2020-001070

[9] De las Heras M, Ortín A, Borobia M, Navarro T. Enzootic nasal adenocarcinoma in sheep: An update. Small Ruminant Research. 2019;180:131-134. DOI: 10.1007/978-3-642-55638-8_8

[10] Ortín A, Cousens C, Minguijon E, Pascual Z, de Villarreal MP, Sharp JM, et al. Characterization of enzootic nasal tumour virus of goats: Complete sequence and tissue distribution. The Journal of General Virology. 2003;84:2245-2252. DOI: 10.1099/ vir. $0.19125-0$

[11] McKinnon AO, Thorsen J, Hayes MA, Misener CR. Enzootic nasal adenocarcinoma of sheep in Canada. The Canadian Veterinary Journal. 1982;23(3):88-94

[12] De las Heras M, Ortín A, Cousens C, Minguijón E, Sharp JM. Enzootic nasal adenocarcinoma of sheep and goats. In: Fan H, editor. Jaagsiekte Sheep Retrovirus and Lung Cancer. Current Topics in Microbiology and Immunology. Vol. 275. Berlin, Heidelberg: Springer; 2003. ISBN: 978-3-642-62897-9. DOI: 10.1007/978-3-642-55638-8_8

[13] Švara T, Gombač M, Vrecl M, Juntes P, Pogačnik M. Enzootic nasal adenocarcinoma of sheep. Slovenian Veterinary Research. 2006;43(2):71-75. UDC 619:626.211-006-07:636.3 
Use of Computed Tomography and Thermography for the Diagnosis of Respiratory Disorders... DOI: http://dx.doi.org/10.5772/intechopen.92615

[14] Gunalan S, Kamaliah G, Wan S, Rozita AR, Rugayah M, Osman MA, et al. Sheep oestrosis (Oestrus ovis, Diptera: Oestridae) in Damara crossbred sheep. Malasyan Journal of Veterinary Research. 2011;2:41-49

[15] Gracia MJ, de Arcaute MR, Ferrer LM, Ramo M, Jiménez C, Figueras L. Oestrosis: Parasitism by Oestrus ovis. Small Ruminant Research. 2019;181:91-98. DOI: 10.1016/j.smallrumres.2019.04.017

[16] Gracia MJ, Lucientes J, Peribáñez MA, Castillo JA, Calvete C, Ferrer LM. Epidemiology of Oestrus ovis infection of sheep in Northeast Spain (mid-Ebro Valley). Tropical Animal Health and Production. 2010;42(5):811813. DOI: $10.1007 / \mathrm{s} 11250-009-9503-8$

[17] Özdal N, Tanritanir P, Ilhan F, Değer S. The prevalence of ovine oestrosis (Oestrus ovis Linnaeus, 1761, Diptera: Oestridae) and risk factors in eastern Turkey. Veterinarski Arhiv. 2016;86(3):323-333

[18] Alem F, Kumsa B, Degefu H. Oestrus ovis larval myiasis among sheep and goats in Central Oromia, Ethiopia. Tropical Animal Health and Production. 2010;42(4):697-703. DOI: 10.1007/ s11250-009-9477-6

[19] Gebremedhin EZ. Prevalence of ovine and caprine oestrosis in ambo, Ethiopia. Tropical Animal Health and Production. 2011;43(1):265-270. DOI: 10.1007/s11250-010-9687-y

[20] Ferrer LM, Garcia de Jalon JA, De las Heras M. Atlas de Patología Ovina. Zaragoza, Spain: Servet Diseño y Comunicación S.L.; 2009. p. 312. ISBN10: 8493292117

[21] Benavides J, González L, Dagleish M, Pérez V.

Diagnostic pathology in microbial diseases of sheep or goats. Veterinary Microbiology. 2015;181:15-26. DOI: 10.1016/j.vetmic.2015.07.012
[22] Castells E, Lacasta D, Climent M, Pérez M, Sanromán F, Jiménez C, et al. Diagnostic imaging techniques of the respiratory tract of sheep. Small Ruminant Research. 2019;180:112-126. DOI: 10.1016/j.smallrumres.2019.05.021

[23] Freeman DE. Sinus disease. Veterinary Clinics: Equine Practice. 2003;19(1):209-243. DOI: 10.1016/ S0749-0739(02)00062-7

[24] Jesse FA, Abba Y, Sadiq MA, Umer M, Chung ELT, Bitrus AA, et al. A suspected case of suppurative frontal sinusitis in a Friesian heifer: Clinical management. International Journal of Livestock Research. 2016;6(8):50-54. DOI: 10.5455/ ijlr.20160816055652

[25] Kumar PR, Prasad VD, Sreenu M, Raju DB. Surgical management of frontal sinusitis in a buffalo. Research \& Reviews: Journal of Veterinary Science and Technology. 2018;6(1):3-5. DOI: 10.37591/rrjovst.v6i1.553

[26] Mehra P, Jeong D. Maxillary sinusitis of odontogenic origin. Current Allergy and Asthma Reports. 2009;9(3):238243. DOI: $10.1007 / \mathrm{s} 11882-009-0035-0$

[27] Schild CO, Caffarena RD, Rabaza A, Banchero G, Giannitti F, Dantas AF, MaiaLA.RietF.Nasal conidiobolomycosis in a sheep (Ovis aries) in Uruguay. Veterinaria (Montevideo). 2016;52(203):4

[28] Daniela M. The prevalence of wormy sinusitis in goats from the west side of our country. Scientific Papers Animal Science and Biotechnologies. 2008;41(2):762-764

[29] Gergeleit H, Bienert-Zeit A, Ohnesorge B. Cytologic and microbiological examination of secretions from the paranasal sinuses in horses and other species. Journal of Equine Veterinary Science. 2018;61:2231. DOI: 10.1016/j.jevs.2017.11.001 
[30] Sáez T, Ramos JJ, García de Jalón JA, Unzueta A, Loste A. Laryngeal hemiplegia in a ram associated with Sarcocystis species infection. The Veterinary Record. 2003;153(1):27-28. DOI: $10.1136 / v r .153 .1 .27$

[31] Edmunds JL, Mcwan MN. Factors affecting the development of laryngeal chondritis in sheep. Large Animal Review. 2017;23(6):219-222. Held on OpenAIR [online]. Available from: https://openair.rgu.ac.uk

[32] Climent S, Sarasa M, Muniesa P, Latorre R, Terrado J, Climent M. Embriología y anatomía veterinaria Vol.2: Cabeza, aparatos respiratorio, digestivo y urogenital. SNC y órganos de los sentidos. Zaragoza: Acribia; 2012. ISBN: 978-84-200-1166-0

[33] Kim KJ, Critz AM, Crandall ED. Transport of water and solutes across sheep visceral pleura. The American Review of Respiratory Disease. 1979;120:883-892. DOI: 10.1164/ arrd.1979.120.4.883

[34] Lacasta D, González JM, Navarro T, Saura F, Acín C, Vasileiou NGC. Significance of respiratory diseases in the health management of sheep. Small Ruminant Research. 2019;181:99-102. DOI: 10.1016/j.smallrumres.2019.03.004

[35] Ortega M, González JM, Ramos JJ, Ferrer LM, Ruiz de Arcaute M, Lacasta D, et al. Estudio de las alteraciones de la tráquea en el ganado ovino: Descripción y prevalencia. In: XLII Congreso Nacional y XVIII Congreso Internacional de la Sociedad Española de Ovinotecnia y Caprinotecnia, 20-22 September 2017; Salamanca, Spain. 2017. pp. 373-378

[36] María GA, Miranda de la Lama G. Ovinotécnia: Producción y economía de la especie ovina. In: Aspectos de bienestar animal en la especie ovina. Zaragoza: Prensas Universitarias de Zaragoza; 2009. pp. 57-64. ISBN: 978-84-92521-89-0
[37] Tena L, Ortega M, Jiménez JC, Forcano D, Menjón A, Lacasta D, et al. Estudio de la relación entre el aplastamiento traqueal y las patologías pulmonares en ganado ovino adulto. In: XLIV Congreso Nacional y XX Congreso Internacional de la Sociedad Española de Ovinotecnia y Caprinotecnia; $18-20$ Septiembre 2019; Córdoba, Spain. 2019. pp. $459-463$

[38] Deplazes P, Eckert J, Mathis A, von Samson-Himmelstjerna G, Zahner H. Parasitology in Veterinary Medicine. The Netherlands: Wageningen Academic Publishers; 2016. p. 653. DOI: 10.3920/978-90-8686-274-0

[39] Panayotova-Pencheva MS, Alexandrov MT. Some pathological features of lungs from domestic and wild ruminants with single and mixed protostrongylid infections. Veterinary Medicine International. 2010;741062:9. DOI: $10.4061 / 2010 / 741062$

[40] Al-Anbagi NA. Isolation and identification some bacterial causes of lung abscesses sheep by chromogenic media. Basrah Journal of Veterinary Research. 2016;15(2):360-370. DOI: 10.33762/bvetr.2016.124337

[41] Yegoraw AA, Gebremeskel AK, Tesema TS, Birhanu BT. Aerobic and anaerobic bacterial isolates from the respiratory tract of sheep slaughtered at Addis Ababa Abattoirs Enterprises, Central Ethiopia. Journal Veterinary Medicine Animal Health. 2017;10:284289. DOI: $10.5897 / J V M A H 2017.0574$

[42] Bell S. Respiratory disease in sheep: 1. Differential diagnosis and epidemiology. In Practice. 2008;30(4):200-207

[43] Singer AJ, Talan DA. Management of skin abscesses in the era of methicillin-resistant Staphylococcus aureus. New England Journal of Medicine. 2014;370(11):1039-1047. DOI: 10.1056/NEJMra1212788 
Use of Computed Tomography and Thermography for the Diagnosis of Respiratory Disorders... DOI: $h t t p: / / d x$.doi.org/10.5772/intechopen.92615

[44] de la Fuente R, de las Heras M, Torrijos C, Diez de Tejada P, PérezSancho M, Carrión FJ, et al. Short communication: Isolation frequency of bacteria causing lymphadenitis and abscesses in small ruminants in Central Spain. Small Ruminant Research. 2017;154:5-8. DOI: 10.1016/j. smallrumres.2017.06.022

[45] Abass KS, Mohammed NS, Taleb M, Raheem ZS. Study of bovine and ovine pulmonary and hepatic abscessation at Kirkuk abattoir. Plant Archives. 2019;19(2):1640-1644

[46] Lacasta D, Fernández A, González JM, Ramos JJ, Ortín A, Ferrer LM. Gangrenous pneumonia, ovine respiratory complex and visceral form of caseous lymphadenitis: Relevance in lower respiratory tract disorders of adult sheep. Small Ruminant Research. 2019;180:100-105. DOI: 10.1016/j. smallrumres.2019.08.004

[47] Miller DS, Weiser GC, Ward ACS, Drew ML, Chapman PL. Domestic sheep (Ovis aries) Pasteurellaceae isolates from diagnostic submissions to the Caine veterinary teaching center (1990-2004). Veterinary Microbiology. 2011;150:284-288. DOI: 10.1016/j. vetmic.2011.01.024

[48] Glendinning L, Wright S, Pollock J, Tennant P, Collie D, McLachlan G. Exploring the variability of the sheep lung microbiota. Applied and Environmental Microbiology. 2016;82:3225-3238. DOI: 10.1128/ AEM.00540-16

[49] Scott PR. Overview of Aspiration Pneumonia. MSD Veterinary Manual [Internet]. 2017. Available from: https:// www.msdvetmanual.com/respiratorysystem/aspiration-pneumonia/ overview-of-aspiration-pneumonia [Accessed: 28 January 2020]

[50] Blowey R, Weaver AD. Color Atlas of Diseases and Disorders of Cattle
E-Book. 3rd ed. Mosby Ltd: Elsevier Health Sciences; 2011. p. 280. ISBN: 9780723436867

[51] do Prado Guirro ECB, Martin CC, Hilgert AR, Pagliosa GM, Silva MM.

Clinical, radiographic and pathological analyses of megaesophagus in sheep Case report. Revista Veterinária em Foco. 2017;15(1):54-58

[52] Darcy HP, Humm K, ter

Haar G. Retrospective analysis of incidence, clinical features, potential risk factors, and prognostic indicators for aspiration pneumonia in three brachycephalic dog breeds. Journal of the American Veterinary Medical Association. 2018;253(7):869-876. DOI: 10.2460/javma.253.7.869

[53] Christodoulopoulos G. Maedi-Visna: Clinical review and short reference on the disease status in Mediterranean countries. Small Ruminant Research. 2006;62(1-2):47-53. DOI: 10.1016/j. smallrumres.2005.07.046

[54] Minguijón E, Reina R, Pérez M, Polledo L, Villoria M, Ramírez H, et al. Small ruminant lentivirus infections and diseases. Veterinary Microbiology. 2015;181(1-2):75-89. DOI: 10.1016/j. vetmic.2015.08.007

[55] Luján L, Pérez M, de Andrés D, Reina R. Pulmonary lentivirus infection in sheep. Small Ruminant Research. 2019;181:87-90. DOI: 10.1016/j. smallrumres.2019.05.006

[56] Cousens C, Thonur L, Imlach S, Crawford J, Sales J, Griffiths DJ. Jaagsiekte sheep retrovirus is present at high concentration in lung fluid produced by ovine pulmonary adenocarcinomaaffected sheep and can survive for several weeks at ambient temperatures. Research in Veterinary Science. 2009;87(1):154156. DOI: 10.1016/j.rvsc.2008.11.007

[57] Sonawane GG, Tripathi BN, Kumar R, Kumar J. Diagnosis and 
prevalence of ovine pulmonary adenocarcinoma in lung tissues of naturally infected farm sheep. Veterinary World. 2016;9(4):365-370. DOI: $10.14202 /$ vetworld.2016.365-370

[58] Ortín A, De las Heras M, Borobia M, Ramo MA, Ortega M, Ruiz de Arcaute M. Ovine pulmonary adenocarcinoma: A transmissible lung cancer of sheep, difficult to control. Small Ruminant Research. 2019;176:37-41. DOI: 10.1016/j. smallrumres.2019.05.014

[59] De las Heras M, González L, Sharp JM. Pathology of ovine pulmonary adenocarcinoma. In: Jaagsiekte Sheep Retrovirus and Lung Cancer. Berlin Heidelberg: Springer-Verlag; 2003. pp. 25-54. DOI: 10.1007/978-3-642-55638-8

[60] Griffiths DJ, Martineau HM, Cousens C. Pathology and pathogenesis of ovine pulmonary adenocarcinoma. Journal of Comparative Pathology. 2010;142(4):260-283. DOI: 10.1016/j. jсpa.2009.12.013

[61] Caporale M, Centorame P, Giovannini A, Sacchini F, Di Ventura M, De las Heras M, et al. Infection of lung epithelial cells and induction of pulmonary adenocarcinoma is not the most common outcome of naturally occurring JSRV infection during the commercial lifespan of sheep. Virology. 2005;338(1):144-153. DOI: 10.1016/j. virol.2005.05.018

[62] Benito A. Estudio Sobre la Infección y Transmisión del Retrovirus Ovino de Jaagsiekte en un Rebaño Ovino Afectado de Adenocarcinoma Pulmonar Ovino [thesis]. Zaragoza, Spain: University of Zaragoza; 2010

[63] Palmarini M, Fan H. Retrovirusinduced ovine pulmonary adenocarcinoma, an animal model for lung cancer. Journal of the National Cancer Institute.
2001;93(21):1603-1614. DOI: 10.1093/ jnci/93.21.1603

[64] Grott K, Dunlap JD. Atelectasis. StatPearls [Internet]. 2019. Available from: https://www.ncbi.nlm.nih.gov/ books/NBK545316/ [Accessed: 20 January 2020]

[65] De Clercq D, van Loon G, Lefère L, Deprez P. Ultrasound-guided biopsy as a diagnostic aid in three horses with a cranial mediastinal lymphosarcoma. The Veterinary Record. 2004;154(23):722-726. DOI: 10.1136/ vr.154.23.722

[66] Braun U, Warislohner S, Gerspach C, Ohlerth S, Wanninger S, Borel N. Clinical, sonographic and pathological findings in a Saanen goat with mediastinal thymoma. Schweizer Archiv für Tierheilkunde. 2017;159(3):185-188. DOI: 10.17236/ sat00111

[67] Windsor PA. Control of caseous lymphadenitis. The Veterinary Clinics of North America. Food Animal Practice. 2011;27:93-202. DOI: 10.1016/j. cvfa.2010.10.019

\section{[68] Scott PR, Sargison ND.}

Ultrasonography as an adjunct to clinical examination in sheep. Small Ruminant Research. 2010;92(1-3):108-119. DOI: 10.1016/j.smallrumres.2016.12.021 



\section{Edited by António Monteiro}

This book examines the branch of animal husbandry of sheep farming. It focuses on sheep feeding in regions with extensive sheep farming, such as the Sahel region in Africa and Serra da Estrela, Portugal, and describes the form and importance of using natural resources. Chapters cover such topics as sheep feeding and digestion, how to improve carcass yield, and how technologies can help diagnose and study respiratory pathologies in sheep. 